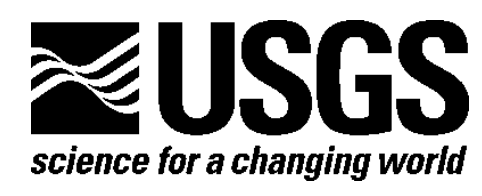

\title{
Assessment of the Geoavailability of Trace Elements from Selected Zinc Minerals
}

By Rhonda L. Driscoll, Phillip L. Hageman, William M. Benzel, Sharon F. Diehl, Suzette Morman, LaDonna M. Choate, and Heather Lowers

Open-File Report 2013-1309

U.S. Department of the Interior

U.S. Geological Survey 


\section{U.S. Department of the Interior \\ SALLY JEWELL, Secretary}

\section{U.S. Geological Survey \\ Suzette M. Kimball, Acting Director}

U.S. Geological Survey, Reston, Virginia: 2014

For more information on the USGS-the Federal source for science about the Earth, its natural and living resources, natural hazards, and the environment-visit http://www.usgs.gov or call 1-888-ASK-USGS

For an overview of USGS information products, including maps, imagery, and publications, visit $h t t p: / / w w w . u s g s . g o v / p u b p r o d$

To order this and other USGS information products, visit $h$ ttp://store.usgs.gov

Suggested citation:

Driscoll, R.L., Hageman, P.L., Benzel, W.M., Diehl, S.F., Morman, Suzette, Choate, L.M., and Lowers, Heather, 2014, Assessment of the geoavailability of trace elements from selected zinc minerals: U.S. Geological Survey Open-File Report 2013-1309, 78 p., http://dx.doi.org/10.3133/ofr20131309.

ISSN 2331-1258 (online)

Any use of trade, firm, or product names is for descriptive purposes only and does not imply endorsement by the U.S. Government.

Although this information product, for the most part, is in the public domain, it also may contain copyrighted materials as noted in the text. Permission to reproduce copyrighted items must be secured from the copyright owner. 


\section{Contents}

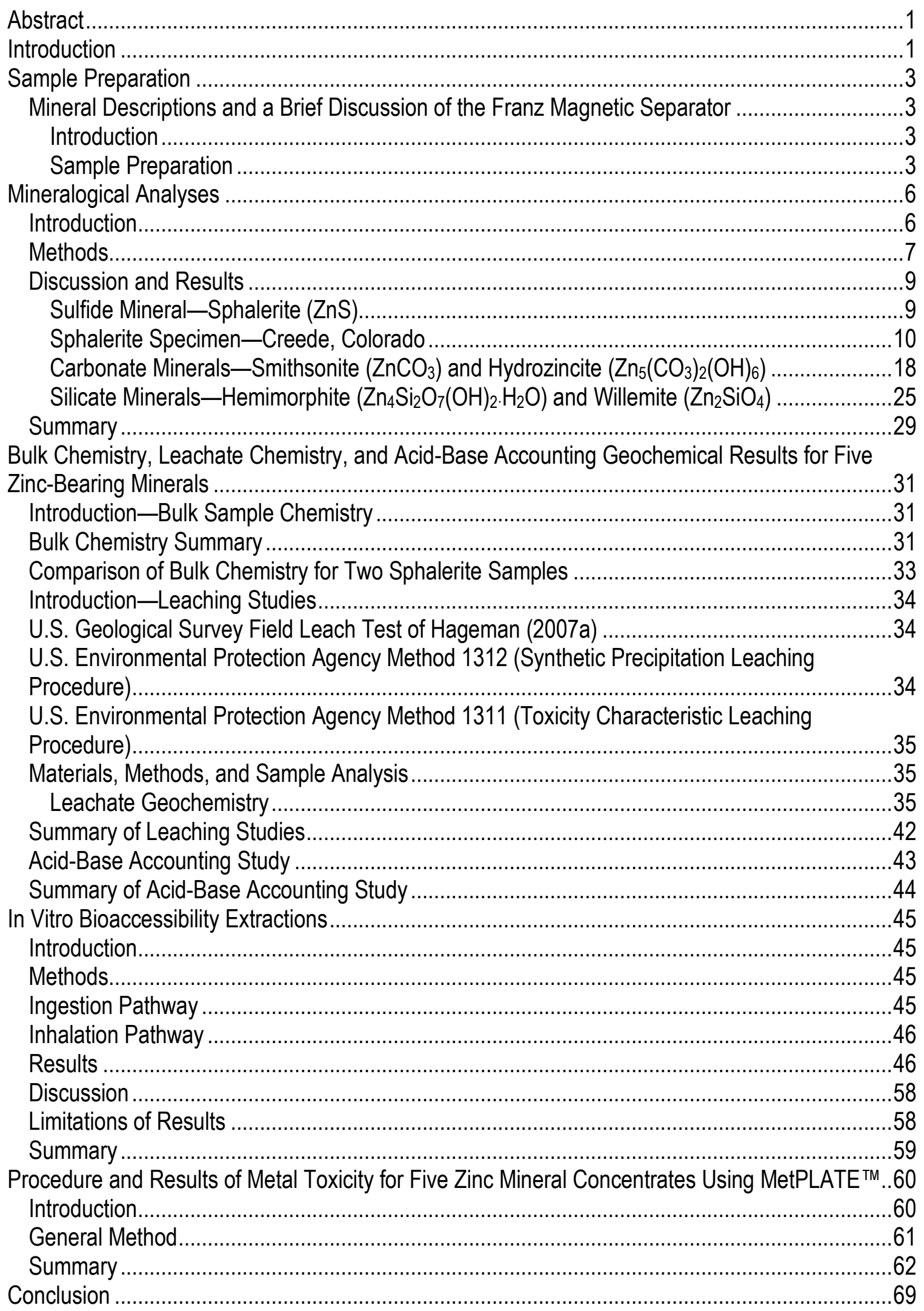




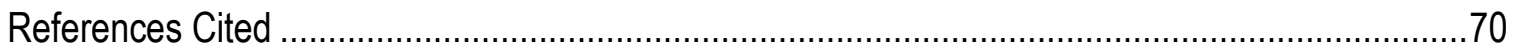

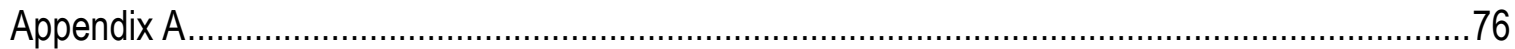

Panalytical X'PERT X-ray Diffractometer Instrument Set-Up .............................................76

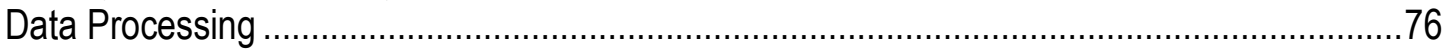

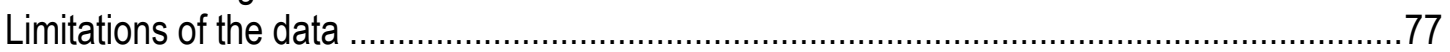

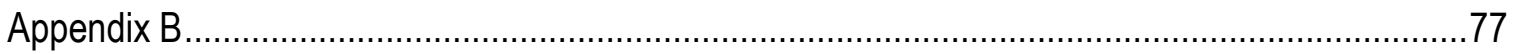

Appendix C ........................................................................................................... link

Appendix D ........................................................................................................ link

\section{Figures}

Figure 1. Sphalerite unit cell showing zinc and sulfur sites. Metal substitutions occur at the zinc sites ....

Figure 2. A. Photograph of a sphalerite hand sample from Creede, Colorado. Sphalerite is a vein-filling cement in brecciated host rock. B. Scanning electron image showing sphalerite intergrown with quartz and potassium feldspar. Galena is common as micron-size inclusions. $\mathrm{Kspar}$, potassium feldspar. C. Scanning electron micrograph showing intergrown sphalerite, pyrite, and galena in veins. Galena $(\mathrm{PbS})$ has partially oxidized to anglesite $\left(\mathrm{PbSO}_{4}\right)$. D. Scanning electron micrograph of dissolution-etched pyrite partially altered to oxidation minerals. Galena is altered to lead sulfate (anglesite). $\mu \mathrm{m}$, micrometer; $\mathrm{cm}$, centimeter .

Figure 3. X-ray diffraction pattern of the Creede, Colorado, sphalerite identifies the minerals present. The center region of the scan is expanded to show trace phases.

S, sphalerite; G, galena; Q, quartz; O, orthoclase; P, pyrite; C, chlorite; deg, degree.

Figure 4. A. Photograph of a massive sphalerite specimen from the Balmat, New York, sedimentary exhalative deposit (SEDEX). B. Backscatter scanning electron image showing dark-gray oxidation-alteration minerals formed along sphalerite grain boundaries and fractures. C. Scanning electron image showing accessory sulfide minerals galena and pyrite in sphalerite. Qtz, quartz; $\mu \mathrm{m}$, micrometer; $\mathrm{cm}$, centimeter.

Figure 5. X-ray diffraction pattern of the Balmat, New York, sphalerite. Sphalerite and quartz are observed in the pattern as well as a $7 \AA$ (angstroms) clay that is most likely kaolinite but may be chlorite. Three other low-intensity reflections are indicated in the figure by their d-spacing $(\AA)$ and represent one or more trace phases that are not identified. These reflections were evaluated by scanning electron microscope analysis, but no certain mineral identifications can be made. Q, quartz; S, sphalerite; deg, degree.

Figure 6. Smithsonite unit cell. Smithsonite forms a limited solid solution with rhodochrosite $\left(\mathrm{MnCO}_{3}\right)$ and siderite $\left(\mathrm{FeCO}_{3}\right)$. A wide variety of metals can substitute for zinc in the structure.....19 Figure 7. Smithsonite: A. Transmitted-light micrograph of radiating smithsonite crystals and accessory iron oxide minerals. B. Backscatter scanning electron image displaying intergrown smithsonite (medium gray) and hemimorphite (light gray) with accessory lead carbonate (brightwhite areas) preferentially hosted in hemimorphite. C. Scanning electron micrograph showing element compositional zonation in smithsonite. Light-gray bands are cadmium-rich; darker bands are calcium-rich. D. Cadmium-element distribution map of area depicted in C. Light-purple bands highlight cadmium enrichment, which is concentrated in the outermost areas of late-stage crystallization. E. Zinc distribution map of $\mathrm{C}$ and $\mathrm{D}$ indicating the homogeneous distribution of zinc, which contrasts with the zoned distribution of cadmium and calcium. F. Backscatter scanning electron image of lead zoning in zinc silicate. Of the three intergrown zinc phases present, lead is preferentially hosted in growth zones in willemite. $\mu \mathrm{m}$, micrometer. 
Figure 8. X-ray diffraction pattern of the smithsonite sample. Several other minerals are identified in the pattern including hemimorphite, quartz, willemite, and chlorite. The center region of the scan is expanded to show trace minerals. $\mathrm{S}$, smithsonite; $\mathrm{H}$, hemimorphite; Q, quartz; W, willemite; C, chlorite; deg, degree

Figure 9. Hydrozincite: A. Transmitted-light photomicrograph showing a cross section of radiating hydrozincite crystals in botryoidal masses. B. Scanning electron image showing porous masses of radiating hydrozincite crystals. Hydrozincite is accompanied by calcite and accessory lead, silver, antimony, and copper minerals (bright-white spots). $\mu \mathrm{m}$, micrometer ........23

Figure 10. X-ray diffraction pattern of the hydrozincite sample. The center region of the scan is expanded to show trace phases. C, calcite; W, willemite; H, hematite; deg, degree.

Figure 11. Hydrozincite unit cell is shown without the hydrogen atoms. The cell is monoclinic; zinc occurs along planes through the crystal separated by carbonate groups....

Figure 12. Hemimorphite unit cell; water molecules consist of cross-hatched oxygen and blue hydrogen atoms. The cell contains channels that are sufficiently large to allow metal atoms and water inside. These channel-fill metals are exchangeable 26

Figure 13. Willemite unit cell showing the rhombohedral form. The channels formed in the structure are not large enough to allow metal atoms.

Figure 14. Hemimorphite/willemite: A. Transmitted-light photomicrograph of radiating hemimorphite crystals in a cross section of a botryoidal mass. B. Backscatter electron image of intergrown hemimorphite and willemite. Iron and manganese oxides occur along grain boundaries. C. Amorphous iron and manganese alteration/oxidation minerals are host to lead and other metals. $\mu \mathrm{m}$, micrometer

Figure 15. X-ray diffraction pattern for hemimorphite/willemite specimen. Calcite and hematite are also identified in the pattern. The center region of the scan is expanded to show trace phases. $\mathrm{H}$ (red), hemimorphite; W, willemite; $\mathrm{C}$, calcite; $\mathrm{H}$ (green), hematite; deg, degree 29

Figure 16. (Log) Bulk zinc concentration using inductively coupled plasma-mass spectrometry (ICP-MS) for five mineral samples. Mg/kg, milligrams per kilogram...

Figure 17. Bulk major-element profile-five zinc minerals. Mg $/ \mathrm{kg}$, milligrams per kilogram.........32

Figure 18. Bulk trace-element profile_-five zinc samples. Mg/kg, milligrams per kilogram ..........33

Figure 19. Comparison of selected bulk chemistry results for the Creede, Colorado, and Balmat, New York, sphalerite samples. Mg/kg, milligrams per kilogram

Figure 20. Leachate $\mathrm{pH}$ values for five zinc minerals using five leach tests. FLT, field leach test; SPLP, synthetic precipitation leaching procedure; TCLP, toxicity characteristic leaching procedure.

Figure 21. Leachate specific conductance (SC) values for five zinc mineral samples using five leach tests. FLT, field leach test; SPLP, synthetic precipitation leaching procedure; TCLP, toxicity characteristic leaching procedure; $\mu \mathrm{S} / \mathrm{cm}$, microSiemens per centimeter.

Figure 22. Zinc results for sphalerite (Balmat, New York). ICP-MS, inductively coupled plasma-mass spectrometry; mg/kg, milligrams per kilogram; FLT, field leach test; SPLP, synthetic precipitation leaching procedure; TCLP, toxicity characteristic leaching procedure

Figure 23. Zinc results for sphalerite (Creede). ICP-MS, inductively coupled plasma-mass spectrometry; $\mathrm{mg} / \mathrm{kg}$, milligrams per kilogram; FLT, field leach test; SPLP, synthetic precipitation leaching procedure; TCLP, toxicity characteristic leaching procedure

Figure 24. Zinc results for hemimorphite. ICP-MS, inductively coupled plasma-mass spectrometry; $\mathrm{mg} / \mathrm{kg}$, milligrams per kilogram; FLT, field leach test; SPLP, synthetic precipitation leaching procedure; TCLP, toxicity characteristic leaching procedure 
Figure 25. Zinc results for smithsonite. ICP-MS, inductively coupled plasma-mass spectrometry; mg/kg, milligrams per kilogram; FLT, field leach test; SPLP, synthetic precipitation leaching procedure; TCLP, toxicity characteristic leaching procedure

Figure 26. Zinc results for hydrozincite. ICP-MS, inductively coupled plasma-mass spectrometry; mg/kg, milligrams per kilogram; FLT, field leach test; SPLP, synthetic precipitation leaching procedure; TCLP, toxicity characteristic leaching procedure .

Figure 27. Field leach test (FLT) leachate plot A: Graph plot of selected elements and their concentration in leachates produced using the 5-minute field-leach test (USGS FLT) versus the zinc mineral. SEDEX, sedimentary exhalative deposit; $\mu \mathrm{g} / \mathrm{L}$, micrograms per liter........42 Figure 28. Acid-base accounting (ABA) test results for five zinc-bearing mineral samples. Kg, kilograms

Figure 29. Bioaccessibility of zinc (Zn) for Balmat, New York, and Creede, Colorado, sphalerite samples measured in simulated gastric fluid (SGF), simulated intestinal fluid (SIF), simulated lung fluid (SLF), and simulated phagolysosomal fluid (SPF) presented as the percent of the solid soluble in the fluid.

Figure 30. Bioaccessibility of zinc $(\mathrm{Zn})$ for hemimorphite sample measured in simulated gastric fluid (SGF), simulated intestinal fluid (SIF), simulated lung fluid (SLF), and simulated phagolysosomal fluid (SPF) presented as the percent of the solid soluble in the fluid

Figure 31. Bioaccessibility of zinc $(Z n)$ for hydrozincite/willemite sample measured in simulated gastric fluid (SGF), simulated intestinal fluid (SIF), simulated lung fluid (SLF), and simulated phagolysosomal fluid (SPF) presented as the percent of the solid soluble in the fluid.

Figure 32. Bioaccessibility of zinc $(\mathrm{Zn})$ for smithsonite sample measured in simulated gastric fluid (SGF), simulated intestinal fluid (SIF), simulated lung fluid (SLF), and simulated phagolysosomal fluid (SPF) presented as the percent of the solid soluble in the fluid 53

Figure 33. Bioaccessibility of arsenic (As) for Balmat (Bal) and Creede sphalerite samples measured in simulated gastric fluid (SGF), simulated intestinal fluid (SIF), simulated lung fluid (SLF), and simulated phagolysosomal fluid (SPF) presented as the percent of the solid soluble in the fluid. RL, reporting level.

Figure 34. Bioaccessibility of arsenic (As) for hemimorphite sample measured in simulated gastric fluid (SGF), simulated intestinal fluid (SIF), simulated lung fluid (SLF), and simulated phagolysosomal fluid (SPF) presented as the percent of the solid soluble in the fluid

Figure 35. Bioaccessibility of arsenic (As) for hydrozincite/willemite sample measured in simulated gastric fluid (SGF), simulated intestinal fluid (SIF), simulated lung fluid (SLF), and simulated phagolysosomal fluid (SPF) presented as the percent of the solid soluble in the fluid....54

Figure 36. Bioaccessibility of arsenic (As) for smithsonite sample measured in simulated gastric fluid (SGF), simulated intestinal fluid (SIF), simulated lung fluid (SLF), and simulated phagolysosomal fluid (SPF) presented as the percent of the solid soluble in the fluid.... .55

Figure 37. Bioaccessibility of cadmium (Cd) for Balmat (Bal) and Creede sphalerite samples measured in simulated gastric fluid (SGF), simulated intestinal fluid (SIF), simulated lung fluid (SLF), and simulated phagolysosomal fluid (SPF) presented as the percent of the solid soluble in the fluid. RL, reporting level.

Figure 38. Bioaccessibility of cadmium $(\mathrm{Cd})$ for hemimorphite sample measured in simulated gastric fluid (SGF), simulated intestinal fluid (SIF), simulated lung fluid (SLF), and simulated phagolysosomal fluid (SPF) presented as the percent of the solid soluble in the fluid 56

Figure 39. Bioaccessibility of cadmium ( $\mathrm{Cd}$ ) for hydrozincite/willemite sample measured in simulated gastric fluid (SGF), simulated intestinal fluid (SIF), simulated lung fluid (SLF), and simulated phagolysosomal fluid (SPF) presented as the percent of the solid soluble in the fluid....57 
Figure 40. Bioaccessibility of cadmium (Cd) for smithsonite sample measured in simulated gastric fluid (SGF), simulated intestinal fluid (SIF), simulated lung fluid (SLF), and simulated phagolysosomal fluid (SPF) presented as the percent of the solid soluble in the fluid

Figure 41. ß-galactosidase catalyzed hydrolysis of chlorophenol red-ß-galactopyranoside (Bitton and Koopman, 1997; Rossel and others, 1997; and Ward and others, 2005)

Figure 42. A developed 96-well MetPLATE ${ }^{\mathrm{TM}}$ bioassay showing negative (toxic) and positive (nontoxic) controls and dilution series for several water samples

Figure 43. Percent inhibition of serial dilutions of the U.S. Geological Survey-field leach test solution compared to the zinc concentrations (in micrograms per liter) for the mineral hemimorphite. $\mathrm{EC}_{50}$, half-maximal effective concentration

Figure 44. Percent inhibition of serial dilutions of the U.S. Geological Survey-field leach test solution compared to the zinc concentrations (in micrograms per liter) for the mineral hydrozincite. $\mathrm{EC}_{50}$, half-maximal effective concentration

Figure 45. Percent inhibition of serial dilutions of the U.S. Geological Survey-field leach test solutions compared to the zinc concentrations (in micrograms per liter) for the minerals smithsonite, sphalerite (Balmat, New York), and sphalerite (Creede, Colorado). EC $\mathrm{C}_{50}$, half-maximal effective concentration.

Figure 46. Percent inhibition of serial dilutions of the U.S. Geological Survey-field leach test solution compared to the zinc concentrations (in micrograms per liter) for duplicate leaches of sphalerite (Balmat, New York). EC 50 , half-maximal effective concentration ....

Figure 47. Percent inhibition of serial dilutions of the U.S. Geological Survey-field leach test solution compared to the zinc concentrations (in micrograms per liter) for the mineral hydrozincite; the five dilutions nearest 50-percent inhibition with the fitted logarithmic curve. $\mathrm{EC}_{50}$, half-maximal effective concentration

Figure 48. Percent inhibition of serial dilutions of the U.S. Geological Survey-field leach test solution compared to the zinc concentrations (in micrograms per liter) for the minerals smithsonite, sphalerite (Balmat, New York), and sphalerite (Creede, Colorado); the seven (smithsonite), six (sphalerite (Creede)), or ten (sphalerite (Balmat)) dilutions nearest 50-percent inhibition with the fitted logarithmic curve. $\mathrm{EC}_{50}$, half-maximal effective concentration

\section{Tables}

Table 1. Microprobe data for zinc minerals

Table 2. Semiquantitative mineralogy using whole-pattern-fit method. Mineral percentages reported as percentage of crystalline components. Amorphous content reported as percentage of bulk specimen

Table 3. Total concentration, leachate concentration, and bioaccessibility of selected trace metals

Table 4. Summary of the $\mathrm{EC}_{50}$ (half-maximal effective concentration) values and 100-percent leachate concentrations for zinc, cadmium, lead, calcium, magnesium, sulfate chlorine, and pH (from P. Hageman, this volume) for five zinc-bearing minerals and diluent. 


\section{Initialisms and Acronyms}

$\begin{array}{ll}\text { ASTM } & \begin{array}{l}\text { American Society for Testing and Materials International } \\ \text { CVAFS }\end{array} \\ \text { cold-vapor atomic fluorescence } \\ \text { DI } & \text { deionized } \\ \text { EC } & \text { half-maximal effective concentration } \\ \text { EDS } & \text { energy-dispersive spectroscopy } \\ \text { EMPA } & \text { electron microprobe analysis } \\ \text { FLT } & \text { field leach test } \\ \text { HDPE } & \text { high-density polyethylene } \\ \text { IC } & \text { ion chromatography } \\ \text { ICP-AES } & \text { inductively coupled plasma-atomic emission spectrometry } \\ \text { ICP-MS } & \text { inductively coupled plasma-mass spectrometry } \\ \text { IVBA } & \text { in vitro bioaccessibility } \\ \text { NAP } & \text { net acid production } \\ \text { RL } & \text { reported level } \\ \text { SC } & \text { specific conductance } \\ \text { SEDEX } & \text { sedimentary exhalative deposit } \\ \text { SEM } & \text { scanning electron microscope } \\ \text { SGF } & \text { simulated gastric fluid } \\ \text { SIF } & \text { simulated intestinal fluid } \\ \text { SLF } & \text { simulated lung fluid } \\ \text { SPF } & \text { simulated phagolysosomal fluid } \\ \text { SPLP } & \text { synthetic precipitation leaching procedure } \\ \text { TCLP } & \text { toxicity characteristic leaching procedure } \\ \text { USEPA } & \text { United States Environmental Protection Agency } \\ \text { XRD } & \text { X-ray diffraction } \\ & \end{array}$




\title{
Assessment of the Geoavailability of Trace Elements from Selected Zinc Minerals
}

\author{
By Rhonda L. Driscoll, Phillip L. Hageman, William M. Benzel, Sharon F. Diehl, Suzette Morman, \\ LaDonna M. Choate, and Heather Lowers
}

\begin{abstract}
This assessment focused on five zinc-bearing minerals. The minerals were subjected to a number of analyses including quantitative X-ray diffraction, optical microscopy, leaching tests, and bioaccessibility and toxicity studies. Like a previous comprehensive assessment of five copper-bearing minerals, the purpose of this assessment was to obtain structural and chemical information and to characterize the reactivity of each mineral to various simulated environmental and biological conditions. As in the copper minerals study, analyses were conducted consistent with widely accepted methods. Unless otherwise noted, analytical methods used for this study were identical to those described in the investigation of copper-bearing minerals.

Two sphalerite specimens were included in the zinc-minerals set. One sphalerite was recovered from a mine in Balmat, New York; the second came from a mine in Creede, Colorado. The location and conditions of origin are significant because, as analyses confirmed, the two sphalerite specimens are quite different. For example, data acquired from a simulated gastric fluid (SGF) study indicate that the hydrothermally formed Creede sphalerite contains orders of magnitude higher arsenic, cadmium, manganese, and lead than the much older metamorphic Balmat sphalerite. The SGF and other experimental results contained in this report suggest that crystallizing conditions such as temperature, pressure, fluidization, or alteration processes significantly affect mineral properties - properties that, in turn, influence reactivity, solubility, and toxicity.

The three remaining minerals analyzed for this report-smithsonite, hemimorphite, and hydrozincite — are all secondary minerals or alteration products of zinc-ore deposits. In addition, all share physical characteristics such as tenacity, density, streak, and cleavage. Similarities end there. The chemical composition, unit-cell parameters, acid-neutralizing potential, and other observable and quantifiable properties indicate very different minerals. Only one of each of these minerals was studied. Had this assessment included multiples of these minerals, geochemical and mineralogical distinctions would have emerged, similar to the results for the two sphalerite specimens.
\end{abstract}

\section{Introduction}

Curiosity about minerals dates back to the earliest humans. With only eyes, tongues, and scratching tools, Paleolithic and indigenous peoples assessed the importance of minerals and discovered practical uses for them. Could a mineral be fashioned into a 
weapon, a tool, a talisman, or an ornament? The science of today is just as curious about minerals and just as interested in their importance. Does a mineral generate acid? As an airborne particle, does it have the potential to impair the human respiratory system? How soluble is it? How is it structured at the microscopic level? This report is one in a series that attempts to answer these questions using contemporary experimental techniques and technologies.

Five zinc-bearing minerals were selected for this study. To determine the purity of the selected minerals, we relied on X-ray diffraction analysis (XRD) to define and quantify the composition of each mineral. Electron microscopy was used for threedimensional imaging of the zinc samples. Various leach tests were performed to obtain information about solubility, alkalinity, $\mathrm{pH}$, specific conductance, and element mobilization. Experiments to determine the absorption potential of a suite of elements and the effect of liberated elements on microorganism reproduction were also included. These laboratory tests and results are discussed in subsequent separate sections of this report.

In general, data collected from this study indicates that zinc, as a discrete element, may not be harmful to terrestrial life. The potential health risks associated with zincbearing minerals are more likely linked to other elements such as lead, cadmium, and arsenic present in the zinc minerals selected for this study. Our findings suggest that zincbearing minerals from ore deposits or weathered sites warrant comprehensive analyses to determine if elements injurious to plant and animal life are present. 


\title{
Sample Preparation
}

\author{
By Rhonda L. Driscoll
}

\section{Mineral Descriptions and a Brief Discussion of the Franz Magnetic Separator}

\author{
Introduction
}

Five zinc-bearing minerals were purchased from a commercial supplier, and each was reduced to grains and powder for distribution to a team of analysts. The sample preparation process is a critical component of materials characterization. Samples must be reduced to specified size fractions and must be free of contamination to ensure that subsequent analyses yield reliable data.

\section{Sample Preparation}

A zinc-bearing set of mineral specimens was prepared for distribution and analyses. Preparation details can be found in Driscoll and others (2012). A general overview of the preparation method and details not included in Driscoll and others (2012) are described in this report. The zinc-bearing minerals were selected based upon chemistry, variations in type, representative location, monomineralic appearance, and gross weight. The selected specimens included the following:

- Smithsonite $\left(\mathrm{ZnCO}_{3}\right.$, zinc carbonate) - Chihuahua, Mexico; San Antonio Mine, replacement deposit.

- Sphalerite ((Zn, Fe)S, zinc sulfide) -Creede, Colorado; Commodore Mine, vein deposit.

- $\quad$ Sphalerite ((Zn, Fe)S, zinc sulfide)—Balmat, New York; St. Joe No. 3 Mine, buried sulfide ore body or sedimentary system.

- Hemimorphite $\left(\mathrm{Zn}_{4} \mathrm{Si}_{2} \mathrm{O}_{7}(\mathrm{OH})_{2} \cdot \mathrm{H}_{2} \mathrm{O}\right.$, zinc silicate) —Chihuahua, Mexico; Potosí Mine, mineralized vein system.

- Hydrozincite $\left(\mathrm{Zn}_{5}(\mathrm{OH})_{3}\left(\mathrm{CO}_{3}\right)_{2}\right.$, hydrated zinc carbonate)—Dragoon, Arizona; TexasArizona Mine, complex polymetallic zone.

In order to separate the zinc phase from matrix or secondary minerals, some special processing was required. An early project decision to avoid use of organic reagents to achieve separation prevented use of a heavy liquid such as methylene iodide. Consequently, the Frantz magnetic separator was identified as the best means of phase separation/concentration.

After hand specimens were crushed to $\leq 2 \mathrm{~mm}$ (millimeter) using a porcelain mortar and pestle, a one-half-gram split of each was powdered and X-rayed for phase confirmation only (complete qualitative and quantitative X-ray diffraction data for each mineral is detailed in the section that follows). Phases were identified using a Shimadzu 6000 X-ray diffractometer. XRD analyses revealed the presence of associated, secondary, or trace phases in each zinc-bearing specimen: 
- Smithsonite/Chihuahua - minor hemimorphite, minor to trace smectite (hydrous aluminum phyllosilicate with variable amounts of iron, magnesium, alkali metals, alkaline earths, and other cations), and clinochlore $\left(\mathrm{Mg}_{5} \mathrm{Al}\right)\left(\mathrm{AlSi}_{3}\right) \mathrm{O}_{10}(\mathrm{OH})$

- Sphalerite/Creede - minor smithsonite, hemimorphite, quartz $\left(\mathrm{SiO}_{2}\right)$, and clinochlore

- Sphalerite/Balmat - trace quartz

- Hemimorphite/Chihuahua - major willemite $\left((\mathrm{Zn}, \mathrm{Co})_{2} \mathrm{SiO}_{4}\right)$ and hematite $\left.\left(\mathrm{Fe}_{2} \mathrm{O}_{3}\right)\right)$

- Hydrozincite/Dragoon - major willemite

Frantz Magnetic Separator

The Frantz magnetic separator is most effective when used to separate small ( 250 to 180 microns $(0.25$ to $0.18 \mathrm{~mm}, 60$ to 80 mesh ASTM [American Society for Testing and Materials International] E specification)) rounded or equidimensional particles of near- or uniform size into magnetic and nonmagnetic mineral fractions. Mineral concentrates in this size range are preferred and are usually intended for chemical analyses. Coarser grained metalliferous ores -250 to 500 microns $(0.50 \mathrm{~mm}, 35$ mesh ASTM E specification) - have been effectively processed using the Frantz (R. Tripp, USGS, oral commun., 2009). Particles greater than 500 microns are rarely processed on a Frantz separator because they tend to be compound, angular, and generally behave unpredictably on the Frantz. Therefore, magnetically separating grains of approximately $2 \mathrm{~mm}$ (2,000 microns, 10 mesh ASTM E specification) - a size requirement of some specific analyses - required modification of the standard magnetic separation method.

Ordinarily, the Frantz is setup with the magnet positioned at $15^{\circ}$ on the horizontal axis, the bent-stem thistle funnel (also called the hopper) tilted to $15^{\circ}$ on the vertical axis, adjusted to a particle feed rate of between 50 and 70 (minimum 10, maximum 100), and track vibration initially set at about 50 (minimum 10, maximum 100). This ordinary setup was incompatible with the very coarse $\geq 2$ - $\mathrm{mm}$ material. The coarse material jammed in the narrow funnel stem, flooded onto the separation tracks when the jams were loosened, and overflowed, bounced, or stalled on the tracks. The Frantz was modified to produce steady, regulated delivery of the coarse material and steady, measured movement of material down the length of the tracks in the following manner. The bent-stem thistle funnel was replaced by a slightly wider straight-stem thistle funnel positioned at $35^{\circ}$ perpendicular to the tracks. The wider, straight stem prevented particle jamming, and the flatter angle slowed the gravitational movement of the coarse grains. This modification improved grain mobility; material flowed steadily from the hopper, and magnetic and nonmagnetic particles separated and moved down their respective tracks. Nonmagnetic zinc-bearing grain separates, or concentrates, were examined with a microscope; zincmineral grains appeared to dominate the concentrates by about a 4:1 ratio or greater. Nonmagnetic compound or quartz grains were seen most often in the zinc concentrates.

Frantz Magnetic Separator Results

As reported by Rosenblum and Brownfield (1999), the zinc-bearing minerals smithsonite and hemimorphite display paramagnetism ${ }^{1}$ at a magnetic field strength greater than 1.7 amperes (A). The Frantz used for separation in this study has a maximum

\footnotetext{
${ }^{1}$ The property of being weakly attracted to either pole of a magnet. Paramagnetic materials become slightly magnetized when exposed to a magnetic field but lose their magnetism when the field is removed.
} 
magnetic field strength of $1.5 \mathrm{~A}$. The maximum setting was applied to the Chihuahuan smithsonite effectively segregating the paramagnetic smectite and clinochlore from the essentially nonmagnetic zinc-bearing phases. Splits of the nonmagnetic phases were submitted for analyses as a combination smithsonite-hemimorphite.

The Creede sphalerite specimen was also processed on the Frantz to separate the zinc-bearing phases from clinochlore. At a setting of $0.8 \mathrm{~A}$, paramagnetic clinochlore was removed from the sample leaving concentrated zinc minerals and quartz. The nonmagnetic zinc minerals mixture, consisting of major sphalerite and minor smithsonite and hemimorphite, was distributed to analysts with no attempt made to separate quartz. Quartz is a minor constituent, and its removal was not considered critical.

The Balmat sphalerite was nearly pure; it contained insignificant quartz. It was crushed, sieved, and distributed without additional mechanical processing.

The Chihuahuan hemimorphite sample consisted of a strongly magnetic phase (hematite) and an uncertain magnetic phase (willemite). The magnetic susceptibility of willemite is reported in Rosenblum and Brownfield (1999) as either weakly magnetic $(0.30 \mathrm{~A})$ or nonmagnetic $(>1.70 \mathrm{~A})^{2}$. In this particular sample, willemite displayed no magnetic susceptibility. The hematite, however, was easily separated from the hemimorphite-willemite at a Frantz setting of 0.10 A. Analysts were given splits of a mixture containing about 70 percent hemimorphite and 30 percent willemite. Percentages were visually estimated with a binocular microscope.

The last mineral in this set, hydrozincite, was not processed beyond crushing, grinding, and sieving. XRD analysis indicated major hydrozincite-minor willemite. Splits of this mineral mixture were distributed to analysts with a note regarding composition.

The post-Frantz zinc-bearing concentrates were split and distributed according to analytical needs. Analyses included X-ray diffractometry, optical microscopy and scanning electron microscopy (SEM) examinations, bulk and leach chemistry, and bioaccessibility and toxicity investigations. Analytical methods are briefly described in this report, including any modifications. Detailed descriptions of analytical methods are reported in Driscoll and others (2012). Complete analytical data for the zinc-minerals set is reported in appendixes 2 through 4.

\footnotetext{
${ }^{2}$ If $\mathrm{Zn}^{2+}$ is replaced by $\mathrm{Mn}^{2+}$ and $\mathrm{Fe}^{2+}$ in the willemite structure, willemite becomes weakly magnetic. The $\mathrm{Mn}-\mathrm{Fe}$ willemite variation is called troostite. Because the sample willemite was not susceptible to the magnet, minimal to no cation replacement was assumed.
} 


\title{
Mineralogical Analyses
}

\author{
By William B. Benzel, Sharon F. Diehl, and Heather Lowers
}

X-ray Powder Diffraction and Microanalytical Studies: Thin Section, Scanning Electron Microscopy, and Electron Microprobe Analyses Micrographs

X-ray Diffraction Instrument Setup and Specifics: Appendix 1

\section{Introduction}

Mining companies and regulatory agencies have long relied on net carbonate calculations to determine the amount of carbonate overburden necessary to prevent acidrain leaching of waste piles. More recently, work has been completed to measure specific acid-generating reactions from bulk materials that lead to release of metals into the environment (Smith, 2007). The next step necessary to understand metal mobilization is to look at the individual minerals in the waste pile and determine which mineral phases are the major contributors. Studies within these sections mineralogically and chemically characterize a suite of zinc minerals with the intent to gain insights into the relative mobility of zinc and associated elements by various pathways that occur in the environment or the human body.

The bioaccessibility of elements depends upon weathering factors and the specific mineral source. For example, the United States Environmental Protection Agency (USEPA) solid-species studies of lead in monitored blood levels in juvenile swine show widely varying bioaccessibility of lead between cerrusite $\left(\mathrm{PbCO}_{3}\right)$, anglesite $\left(\mathrm{PbSO}_{4}\right)$, and galena (PbS). Although lead has been extensively studied, very little is known about other metal-bearing minerals of industrial importance. The bulk composition of ore minerals and the resident sites of minor and trace elements within minerals are essential to understanding trace-element mobility under various weathering conditions and oredeposit types.

A previous report on the characterization of concentrated copper "monominerals" showed there is a disparity in metal and anion release from similar minerals due to different structural settings, ore-deposit types, trace-element content, or associated mineral assemblages microscopically intergrown in the primary mineral phase (Diehl and others, 2012; Driscoll and others, 2012).

Knowledge of the speciation of elements is important, especially for elements of concern for regulatory standards. Ore minerals are complex with most minerals hosting many individual elements. The bioaccessibility of a specific metal or element is dependent on the mineralogic source. Minerals in different ore-deposit types host different elements; therefore, sphalerite was examined from two different ore-deposit types - a vein system and a sedimentary system - in order to contrast trace-element chemistry in different geological settings that underwent different formation conditions and processes. Leachate and bioaccessibility studies (later sections) record different chemical behavior between the two sphalerite samples; this section on mineralogy explains the chemical residence and content of trace metals that contribute to those differences. 
The zinc-bearing minerals, sphalerite $(\mathrm{ZnS})$, smithsonite $\left(\mathrm{ZnCO}_{3}\right)$, hydrozincite $\left(\mathrm{Zn}_{5}\left(\mathrm{CO}_{3}\right)_{2}(\mathrm{OH})_{6}\right)$, and hemimorphite/willemite mixture $\left(\mathrm{Zn}_{4} \mathrm{Si}_{2} \mathrm{O}_{7}(\mathrm{OH})_{2} \cdot \mathrm{H}_{2} \mathrm{O}\right) /\left(\mathrm{Zn}_{2} \mathrm{SiO}_{4}\right)$ were selected in order to understand weatherability and potential to release constituents into the environment. Sphalerite is a primary zinc ore that forms under a wide temperature range by hydrothermal processes in sedimentary rocks such as sandstone or limestone, in veins cross-cutting coals, and in igneous and metamorphic rocks. Sphalerite forms as euhedral crystals to botryoidal, fibrous, or massive morphologies.

Hemimorphite, hydrozincite, smithsonite, and willemite are all alteration products that form in the oxidation zone of zinc ore deposits. These alteration minerals typically occur as botryoids, which are agglomerated spheres composed of radiating crystals.

Precipitation of botryoidal shapes is a more rapid formation process than precipitation of well-ordered euhedral crystals, and therefore, botryoids may incorporate elevated concentrations of trace elements such as copper and (or) iron or other elements.

The minerals were examined by X-ray powder diffraction, petrographic microscope, scanning electron microscope (SEM), and electron microprobe analysis (EMPA) to (1) identify basic mineralogy and associated structural and textural features, (2) calculate the unit cell of the zinc mineral and estimate the amorphous content of the sample, (3) quantify trace-element content associated with the main mineral phase, and (4) determine the residence, or mode of occurrence, of trace elements, that is, whether trace metals are homogeneously distributed within the mineral or associated with mineral inclusions. By utilizing microanalytical techniques, the residence sites of major, minor, and trace elements can be determined but only at the detection limits of each of the instruments. The microanalytical study complements both the XRD data by validating major mineralogy results as well as showing the presence of accessory minerals that are below XRD detection limits, and the leachate studies by showing the exact mineralogic residence sites of minor to trace elements that are released into solution.

\section{Methods}

An effort was made to pick a clean sample after crushing, but minor amounts of accessory minerals are present that conventional methods of mineral separation do not remove (Driscoll, this volume). Detailed mineral (X-ray and SEM) and chemical (EPMA and leachate) studies were used to identify micro-textural and structural characteristics and elemental distribution within the zinc minerals.

Polished standard thin sections of the five zinc-bearing mineral samples were examined in reflected-light microscopy and with a JEOL 5800LV scanning electron microscope equipped with a Thermo NORAN silicon-drift energy-dispersive spectroscopy (EDS) detector to determine basic mineralogy, identify textures or any structural defects, analyze qualitatively and semiquantitatively trace- and minor-element content, and relate trace-metal distributions to mineral phases. The SEM has an element detection limit of approximately 500-1,000 parts per million (ppm). Backscatter scanning electron imagery was used to help identify and separate the intergrown zinc phases. More dense phases, as well as heavy metals such as lead, appear bright white against less dense phases, which appear in shades of gray.

Concentrations of trace metals in the primary mineral phases were determined with a JEOL JXA-8900 EMPA (table 1). The results reported in table 1 are from select areas of a magnified image where nearly pure mineral phases were analyzed. 
Table 1. Microprobe data for zinc minerals.

[Wt $\%$, weight percent, No, number]

\begin{tabular}{|c|c|c|c|c|c|c|c|c|c|c|c|c|c|c|c|c|c|c|c|c|}
\hline \multirow{6}{*}{ 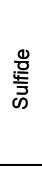 } & & \begin{tabular}{|l|} 
No Analyses \\
\end{tabular} & Zn WT\% & Cu WT\% & Fe WT\% & NiWT\% & Co WT\% & Mn WT\% & CrWT\% & Mg WT\% & Na WT\% & Ca WT\% & Sb WT\% & Cd WT\% & Ag WT\% & $\mathrm{Pb} \mathrm{WT \%}$ & SWT\% & SrWT\% & Total & \\
\hline & Sphalerite Creede & 3 & 66.58 & 0.04 & 0.38 & 0.01 & $\mathrm{BDL}$ & 0.03 & 0.01 & 0.04 & $\mathrm{BDL}$ & $\mathrm{BDL}$ & $\mathrm{BDL}$ & 0.45 & $\mathrm{BDL}$ & $\mathrm{BDL}$ & 32.85 & 0.08 & 100.29 & \\
\hline & ideal stoichiometry & & 67.10 & & & & & & & & & & & & & & 32.90 & & 100.00 & \\
\hline & & No Analyses & Zn WT\% & Cu WT\% & Fe WT\% & NiWT\% & Co WT\% & Mn WT\% & Cr WT\% & Mg WT\% & Na WT\% & Ca WT\% & Sb WT\% & Cd WT\% & Ag WT\% & $\mathrm{Pb}$ WT\% & SWT\% & SrWT\% & Total & \\
\hline & Sphalerite Balmat & 3 & 59.60 & $\mathrm{BDL}$ & 6.67 & 0.05 & 0.01 & 0.12 & $\mathrm{BDL}$ & \begin{tabular}{|l|l|}
0.03 \\
\end{tabular} & $\mathrm{BDL}$ & $\mathrm{BDL}$ & $\mathrm{BDL}$ & 0.10 & $\mathrm{BDL}$ & $\mathrm{BDL}$ & 33.09 & 0.07 & 99.66 & \\
\hline & ideal stoichiometry & & 67.10 & & & & & & & & & & & & & & 32.90 & & 100.00 & \\
\hline \multirow{9}{*}{$\begin{array}{l}\frac{\mathbb{J}}{\pi} \\
\text { ర్ } \\
\frac{0}{\pi} \\
0\end{array}$} & & No Analyses & Zn WT\% & Ca WT\% & Cd WT\% & Co WT\% & Pb WT\% & Ag WT\% & Fe WT\% & Ni WT\% & | Cu WT\% & As WT\% & \begin{tabular}{|l|l|} 
Mn WT\% \\
\end{tabular} & CWT\% & OWT\% & HWT\% & Total & & & \\
\hline & Smithsonite (bright) & 36 & 51.55 & 0.12 & NM & 0.02 & 0.11 & $\mathrm{BDL}$ & 0.00 & 0.00 & 0.02 & $\mathrm{BDL}$ & 0.08 & 9.58 & 38.22 & 0.00 & 99.70 & & & \\
\hline & Smithsonite (medium) & 50 & 50.04 & 1.37 & NM & 0.02 & 0.05 & $\mathrm{BDL}$ & 0.00 & 0.00 & BDL & $\mathrm{BDL}$ & 0.08 & 9.58 & 38.34 & 0.00 & 99.47 & & & \\
\hline & Smithsonite (dark) & 48 & 48.92 & 1.32 & NM & 0.12 & $\mathrm{BDL}$ & $\mathrm{BDL}$ & 0.00 & 0.00 & $\mathrm{BDL}$ & $\mathrm{BDL}$ & 0.08 & 9.58 & 38.07 & 0.00 & 98.09 & & & \\
\hline & Smithsonite (all) & all (134) & 50.05 & 1.02 & NM & 0.05 & 0.03 & $\mathrm{BDL}$ & 0.00 & 0.00 & $\mathrm{BDL}$ & $\mathrm{BDL}$ & 0.08 & 9.58 & 38.21 & 0.00 & 99.02 & & & \\
\hline & ideal stoichiometry & & 52.15 & & & & & & & & & & & 9.58 & 38.28 & & 100.01 & & & \\
\hline & & No Analyses & Si WT\% & Zn WT\% & Cd WT\% & Pb WT\% & Al WT\% & Fe WT\% & Ni WT\% & Cu WT\% & Mn WT\% & Mg WT\% & Ca WT\% & SrWT\% & Na WT\% & SWT\% & OWT\% & HWT\% & $\mathrm{C} \%$ & Total \\
\hline & Hydrozincite & & 0.11 & 42.35 & 0.00 & 1.50 & 0.01 & 0.01 & 0.00 & 0.43 & 0.01 & 0.19 & 0.32 & 0.00 & 0.74 & 0.02 & 11.27 & 0.00 & NM & 56.96 \\
\hline & ideal stoichiometry & & & 59.55 & & & & & & & & & & & & & 34.97 & 1.1 & 4.38 & 100 \\
\hline \multirow{6}{*}{ 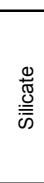 } & & INo Analyses & Zn WT\% & SiWT\% & Cd WT\% & Pb WT\% & Al WT\% & FeWT\% & $\begin{array}{l}\text { NiWT\% } \\
\end{array}$ & \begin{tabular}{|l} 
Cu WT\% \\
\end{tabular} & Mn WT\% & Mg WT\% & \begin{tabular}{|l|} 
Ca WT\% \\
\end{tabular} & SrWT\% & Na WT\% & SWT\% & & & & \\
\hline & Hemimorphite & 3 & 60.56 & 13.27 & 0.00 & 0.00 & 0.00 & 0.00 & 0.01 & 0.00 & \begin{tabular}{|l|l|}
0.01 \\
\end{tabular} & 0.00 & 0.03 & 0.00 & $\frac{\mathrm{Na} \mathrm{V} T \mathrm{\%}}{0.00}$ & 0.00 & $\begin{array}{l}\text { OWT\% } \\
29.98\end{array}$ & $\frac{\mathrm{HWT} \%}{0.00}$ & $\frac{\text { Total }}{103.87}$ & \\
\hline & ideal stoichiometry & & 54.29 & 11.66 & & & & & & & & & & & & & 33.21 & 0.84 & 100.00 & \\
\hline & & No Analyses & Zn WT\% & Si WT\% & Cd WT\% & PbWT\% & AlWT\% & Fe WT\% & Ni WT\% & Cu WT\% & VT\% & Mg WT\% & Ca WT\% & SrWT\% & Na WT\% & SWT\% & OWT\% & HWT\% & Iotal & \\
\hline & Willemite & 3 & 52.01 & 13.08 & 0.00 & 0.00 & 0.00 & 0.02 & 0.01 & 0 & 4.50 & 0.12 & 0.01 & 0.00 & 0.00 & 0.00 & 29.04 & 0.00 & 98.79 & \\
\hline & ideal stoichiometry & & 58.68 & 12.6 & & & & & & & & & & & & & 28.72 & & 100.00 & \\
\hline
\end{tabular}


The average chemical composition represents the mineral of interest, not the bulk specimen chemistry. There has been an increasing awareness that element associations and residence sites of trace metals in minerals are important in determining weathering behavior, not just the concentration of a trace element within a mineral (Diehl and others, 2006, 2007); therefore, a digital element map, showing the spatial distribution of zinc and cadmium in smithsonite, was generated on the electron probe to demonstrate the common zoning of trace metals in ore minerals.

Powder XRD analysis was employed to make two measurements on each specimen. First, the scan was interpreted to identify mineral phases present in the sample. The second measurement determined the unit-cell parameters of the zinc-bearing mineral. The unit cell of each specimen is compared to the calculated unit cell of an idealized pure end-member mineral (a chemically pure mineral with no substitutions). The difference between the calculated and actual mineral unit cells reflects chemical substitutions and strains and stresses in the crystal structure. These factors influence the stability, reactivity, and solubility of the mineral.

A less than 75 -micrometer $(\mu \mathrm{m})$-size separate of each mineral was provided for analysis. This material was further reduced in size to approximately $50 \mu \mathrm{m}$ using an agate mortar and pestle. Two grams (if available) of each hand-ground powder was mixed with $20 \mathrm{~mL}$ (milliliter) of propanol and micronized in a McCrone mill for 4 minutes. The milled particles were less than $5 \mu \mathrm{m}$ in size. After drying in air, the micronized powder was disaggregated by lightly grinding in a mortar and pestle. Next, an appropriate amount of corundum (NOAH Technologies Corporation 1-micron alumina) was added to the sample to yield a mixture with 10-percent-by-weight corundum as an internal standard. The mixture was transferred to a plastic vial containing two polystyrene balls; the vial was shaken for 10 minutes in a Spex Mixer mill. The blended powder was then sieved through a $250-\mu \mathrm{m}$ screen yielding a fluffy powder made up of aggregates of the fine particles. To minimize preferred orientation, the sieved material was side packed into a Scintag XRD sample holder.

X-ray diffraction scans were collected on a Panalytical X'Pert diffractometer with Bragg Brentano geometry, theta-theta motion with a strip detector set to collect only $\mathrm{K} \alpha$ (strongest X-ray spectral line) radiation. The instrument set-up parameters and calibration are listed in appendix 1.

\section{Discussion and Results}

\section{Sulfide Mineral-Sphalerite (ZnS)}

Sphalerite has a zinc ion surrounded by six sulfur atoms arranged in tetrahedral coordination (fig. 1). 


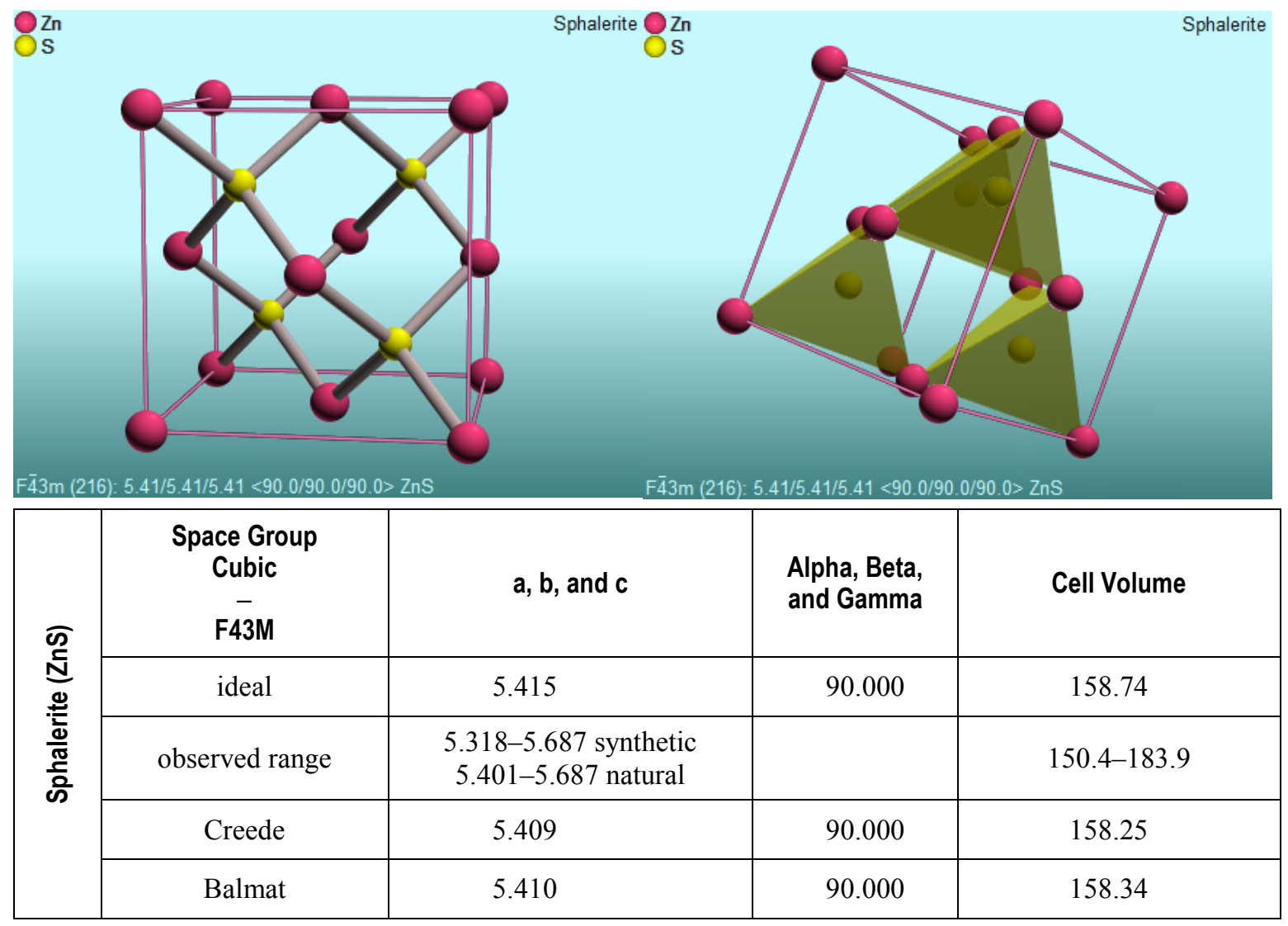

Figure 1. Sphalerite unit cell showing zinc and sulfur sites. Metal substitutions occur at the zinc sites.

Sphalerite almost always contains some iron as well as other metal substitutions for the zinc in the structure, so much so that sphalerite is a major ore for $\mathrm{Zn}$ as well as $\mathrm{Cd}$, In, Ge, and $\mathrm{Ga}$ (Benedetto, 2005). Natural sphalerite has been reported with metal substitutions including individual substitutions of up to 26 percent $\mathrm{Fe}, 5.8$ percent $\mathrm{Mn}$, or 1.7 percent $\mathrm{Cd}$ as well as numerous other elements including $\mathrm{Pb}, \mathrm{Cu}, \mathrm{Hg}, \mathrm{In}, \mathrm{Ga}, \mathrm{Tl}, \mathrm{Au}, \mathrm{Ag}, \mathrm{Sb}$, and $\mathrm{Sn}$ (Palache and others, 1961). Lead and copper are observed in natural sphalerite, both as intergrowths of chalcopyrite and galena and as substitutions in the sphalerite structure.

In addition to the secondary zinc minerals studied in this suite, alteration of sphalerite by oxidation also yields goslarite $\left(\mathrm{ZnSO}_{4}{ }_{7} \mathrm{H}_{2} \mathrm{O}\right)$ and (or) gunningite $\left(\mathrm{Zn}\left(\mathrm{SO}_{4}\right)\left(\mathrm{H}_{2} \mathrm{O}\right)\right)$. Sphalerite can be zoned, and recent studies have shown that some metal substitutions are coupled, such as iron and manganese. Zoned sphalerite may generate cyclic metal releases during weathering reflecting each zone's chemistry. An example of cyclic release can be found in Benedetto (2005) who reported high iron-low manganese followed by low iron-high manganese releases.

\section{Sphalerite Specimen-Creede, Colorado}

Sphalerite from Creede, Colorado, is hosted in a vein system and acts as cement around breccia fragments in the sample studied (fig. $2 A$ ). X-ray diffraction shows the host rock is quartz and orthoclase (fig. $2 B$ ). Accessory minerals include silver-bearing galena and 
pyrite $\left(\mathrm{FeS}_{2}\right)$ as well as oxidation products of these accessory sulfide minerals such as anglesite $\left(\mathrm{PbSO}_{4}\right)$ and amorphous iron oxides, respectively (fig. 2C). Pyrite is deeply etched and altered to amorphous iron sulfate and oxides, which are sinks for adsorbed metals; here the amorphous alteration by-products of oxidized pyrite are host to metals such as lead and arsenic, which were detected by SEM/EDS (fig. 2D). Anglesite is not considered to be a very soluble mineral, but the anglesite is porous and fine grained (figs. $2 C$ and $2 D$ ), which offers a greater surface area for further alteration and dissolution.

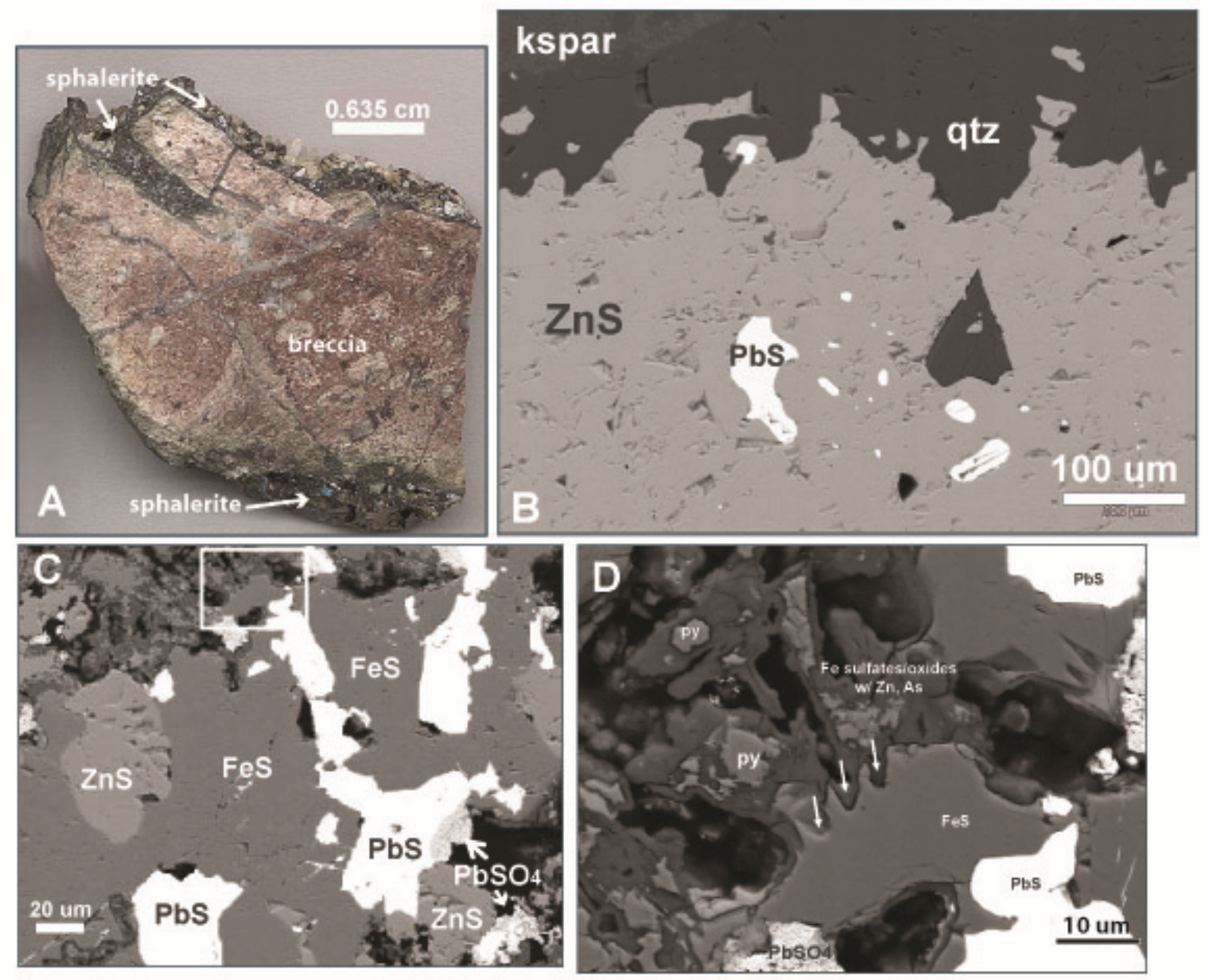

Figure 2. A. Photograph of a sphalerite hand sample from Creede, Colorado. Sphalerite is a vein-filling cement in brecciated host rock. $B$. Scanning electron image showing sphalerite intergrown with quartz and potassium feldspar (kspar). Galena is common as micron-size inclusions. C. Scanning electron micrograph showing intergrown sphalerite, pyrite, and galena in veins. Galena (PbS) has partially oxidized to anglesite $\left(\mathrm{PbSO}_{4}\right)$. $\mathrm{D}$. Scanning electron micrograph of dissolution-etched pyrite partially altered to oxidation minerals. Galena is altered to lead sulfate (anglesite). $\mu \mathrm{m}$, micrometer; $\mathrm{cm}$, centimeter.

The XRD scan of the specimen with the phases identified is presented in figure 3. 


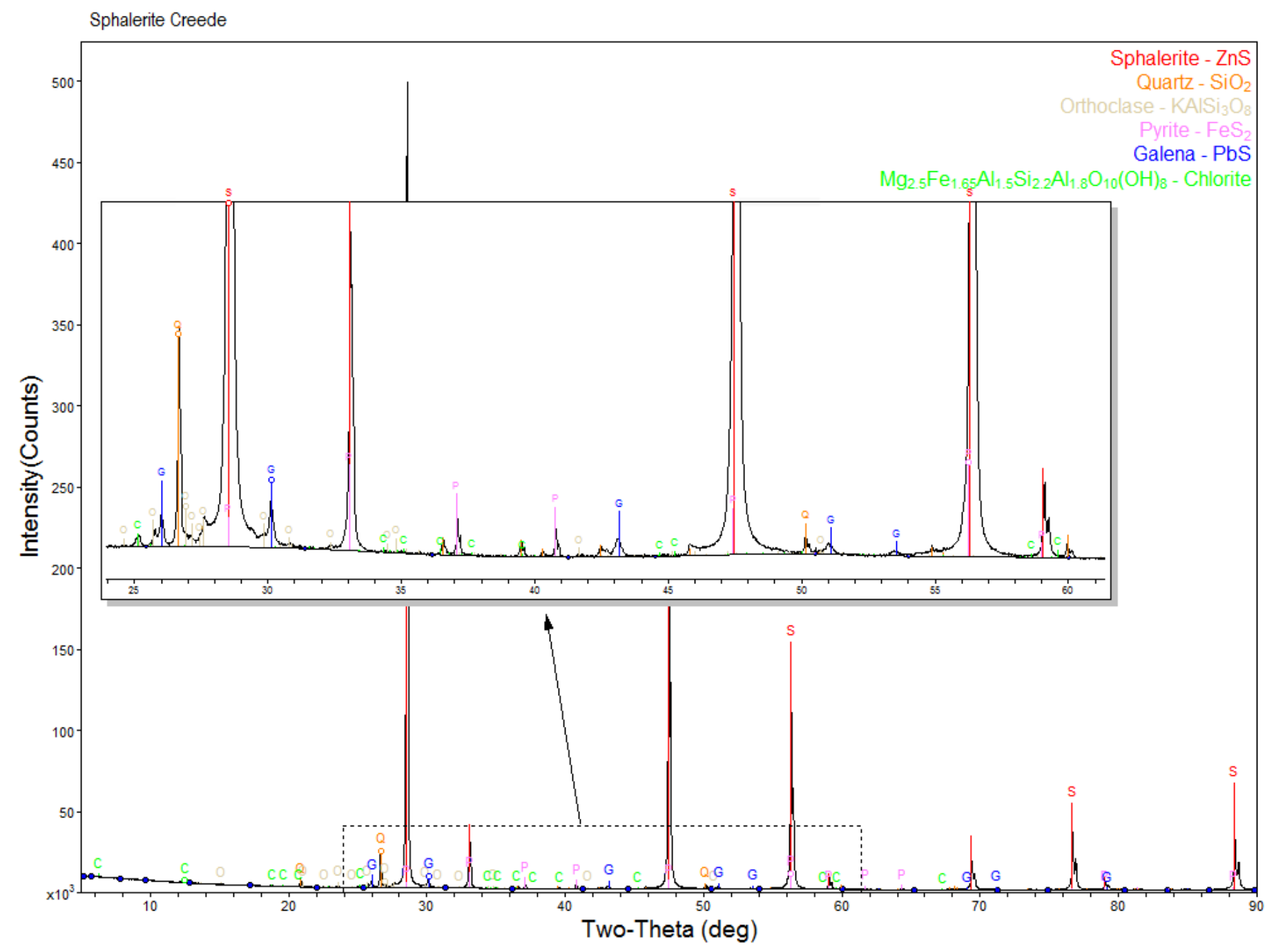

Figure 3. X-ray diffraction pattern of the Creede, Colorado, sphalerite identifies the minerals present. The center region of the scan is expanded to show trace phases. S, sphalerite; G, galena; $Q$, quartz; O, orthoclase; P, pyrite; C, chlorite; deg, degree. 
The refinement of the mineralogy shows the bulk sample is composed of 85 percent sphalerite, 7 percent quartz, 4 percent orthoclase, 3 percent pyrite, 1 percent chlorite and less than 1 percent galena. In addition, the refinement indicates the sample contains 7-percent amorphous component not included in the semiquantitative mineralogy (table 2). 
Table 2. Semiquantitative mineralogy using whole-pattern-fit method. Mineral percentages reported as percentage of crystalline components. Amorphous content reported as percentage of bulk specimen.

[wt\%, weight percent]

\begin{tabular}{|c|c|c|c|c|c|c|c|c|c|c|c|c|c|c|c|c|}
\hline values in wt $\%$ & $\overbrace{\pi}^{\infty}$ & & లే & $\begin{array}{l}n \\
0 \\
0\end{array}$ & 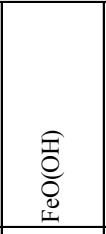 & $\begin{array}{l}0_{0}^{0} \\
\text { I. } \\
\end{array}$ & 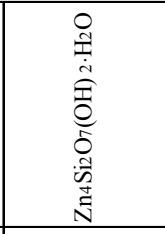 & 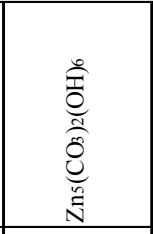 & 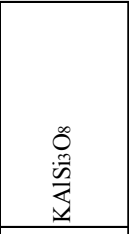 & 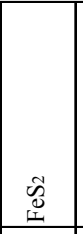 & 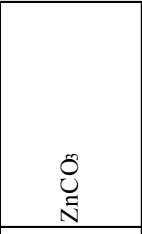 & N & $\begin{array}{l}\text { ర0 } \\
\text { N } \\
\text { N }\end{array}$ & $\delta_{0}^{\prime}$ & & \\
\hline Specimen & calcite & $\begin{array}{c}\text { clay (kaolinte } \\
\text { or chlorite) }\end{array}$ & fluorite & galena & goethite & hematite & hemimorphite & hydrozincite & orthoclase & pyrite & smithsonite & sphalerite & willemite & quartz & total & $\begin{array}{l}\text { amorphous } \\
\text { content }\end{array}$ \\
\hline Sphale rite Creede & & 1 & & $<1$ & & & & & 4 & 3 & & 85 & & 7 & 100 & 7 \\
\hline Sphale rite Balmat & & 3 & & & & & & & & & & 80 & & 17 & 100 & 11 \\
\hline Smithsonite & & $<1$ & & & & & 7 & & & & 92 & & $<1$ & 1 & 100 & 10 \\
\hline Hydrozincite & 1 & & & & & $<1$ & & 97 & & & & & 1 & & 99 & 11 \\
\hline Hemimorphite-Willem & 5 & & $<1$ & & 4 & 3 & 72 & & & & $<1$ & & 16 & & 100 & 13 \\
\hline
\end{tabular}

Semi-quantitative mineralogy calculated using Whole Pattern Fit method. Mineral percentages reported as

percentage of crystalline components. Amorphous content report as percentage of bulk specimen. 
The scan was tested for anglesite, which was observed in the SEM work, but it would not refine in the whole-pattern-fit model. There are interferences between the other mineral phases and anglesite's primary reflections making the identification of trace anglesite by XRD in this sample dubious.

The unit cell of the Creede sphalerite refined to be 5.409 $\AA$ (angstrom) for the cubic-cell axial length with $90^{\circ}$ axial angles (fig. 1). The calculated unit-cell dimensions for an ideal sphalerite are $5.415 \AA$ and axial angle of $90^{\circ}$. Natural sphalerite has been reported with axial dimensions ranging between 5.401 and $5.687 \AA$ with axial angles of $90^{\circ}$. Synthetic sphalerite has extended the range from 5.318 to $5.687 \AA$. The Creede sphalerite has a unit cell close to ideal suggesting that the sphalerite has limited substitution in the zinc sites of the crystal, and this is supported by the microprobe data (table 1) that shows minor to trace substitutions total less than 1 percent in the zinc sites of the mineral.

Sphalerite Specimen—Balmat, New York

Sphalerite from Balmat, New York, is from a sedimentary exhalative deposit (SEDEX). SEM studies found the minor accessory minerals are quartz, pyrite, ilmenite, and secondary alteration oxidation minerals along fractures within the sphalerite (figs. $4 A-4 C$ ) and along grain boundaries. 

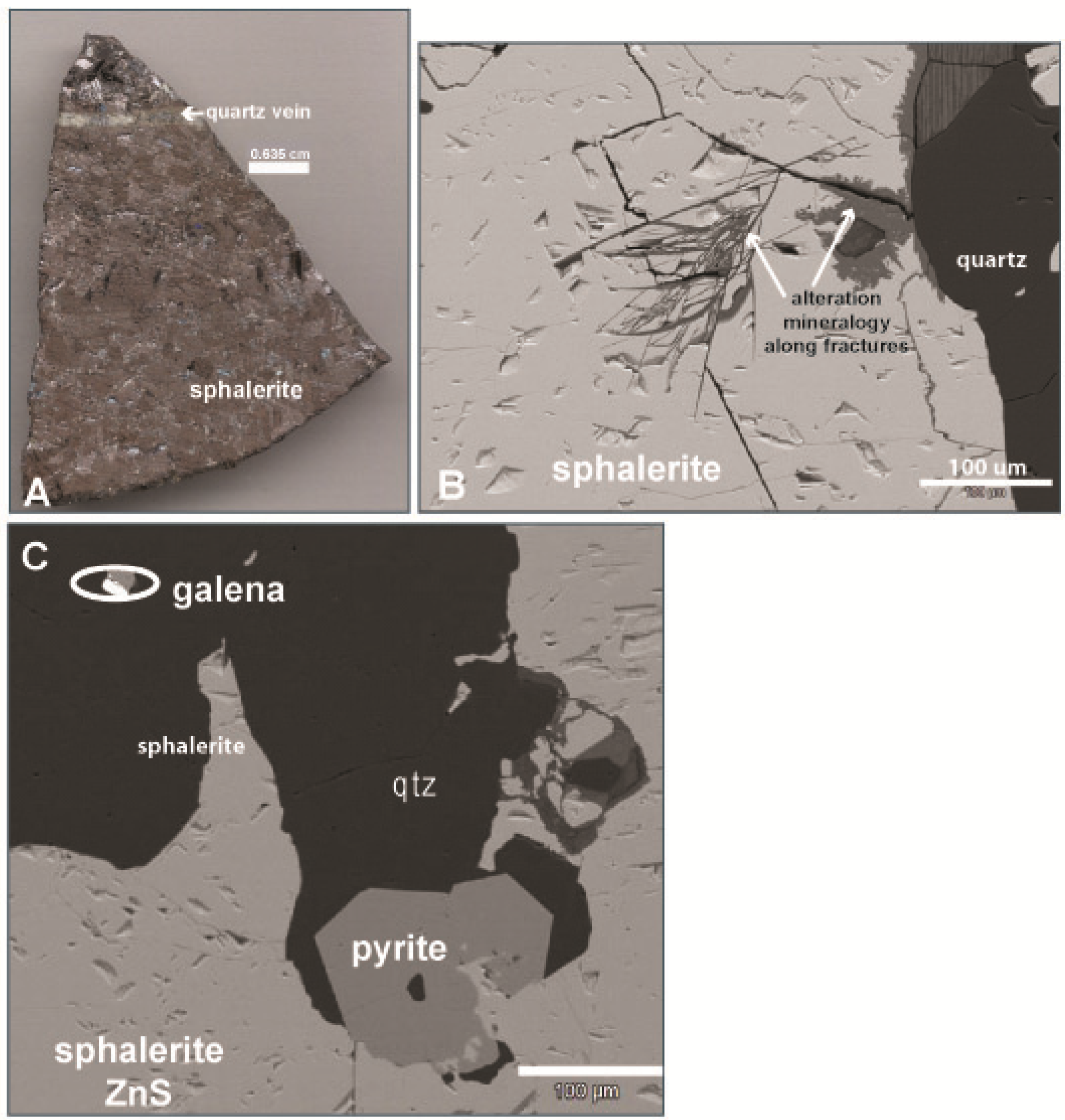

Figure 4. A. Photograph of a massive sphalerite specimen from the Balmat, New York, sedimentary exhalative deposit (SEDEX). B. Backscatter scanning electron image showing dark-gray oxidationalteration minerals formed along sphalerite grain boundaries and fractures. C. Scanning electron image showing accessory sulfide minerals galena and pyrite in sphalerite. Qtz, quartz; $\mu \mathrm{m}$, micrometer; $\mathrm{cm}$, centimeter. 
Bulk XRD analysis shows that the specimen is composed of sphalerite and quartz (fig. 5). There are two minor reflections not assigned in the XRD scan that possibly could be assigned to a nickel pyrite; however, there is not sufficient nickel to support nearly a weight percent of nickel pyrite in the sample. There is at least one more phase present that does not match any of the accessory minerals found by SEM. The refinement of the XRD scan shows the sample is composed of 80 percent sphalerite, 17 percent quartz, and 3 percent clay (a $7 \AA$ phase), most likely kaolinite, but possibly chlorite (table 2). The amorphous content is calculated to be 11 percent of the bulk mineralogy exclusive of the semiquantitative mineral estimates.

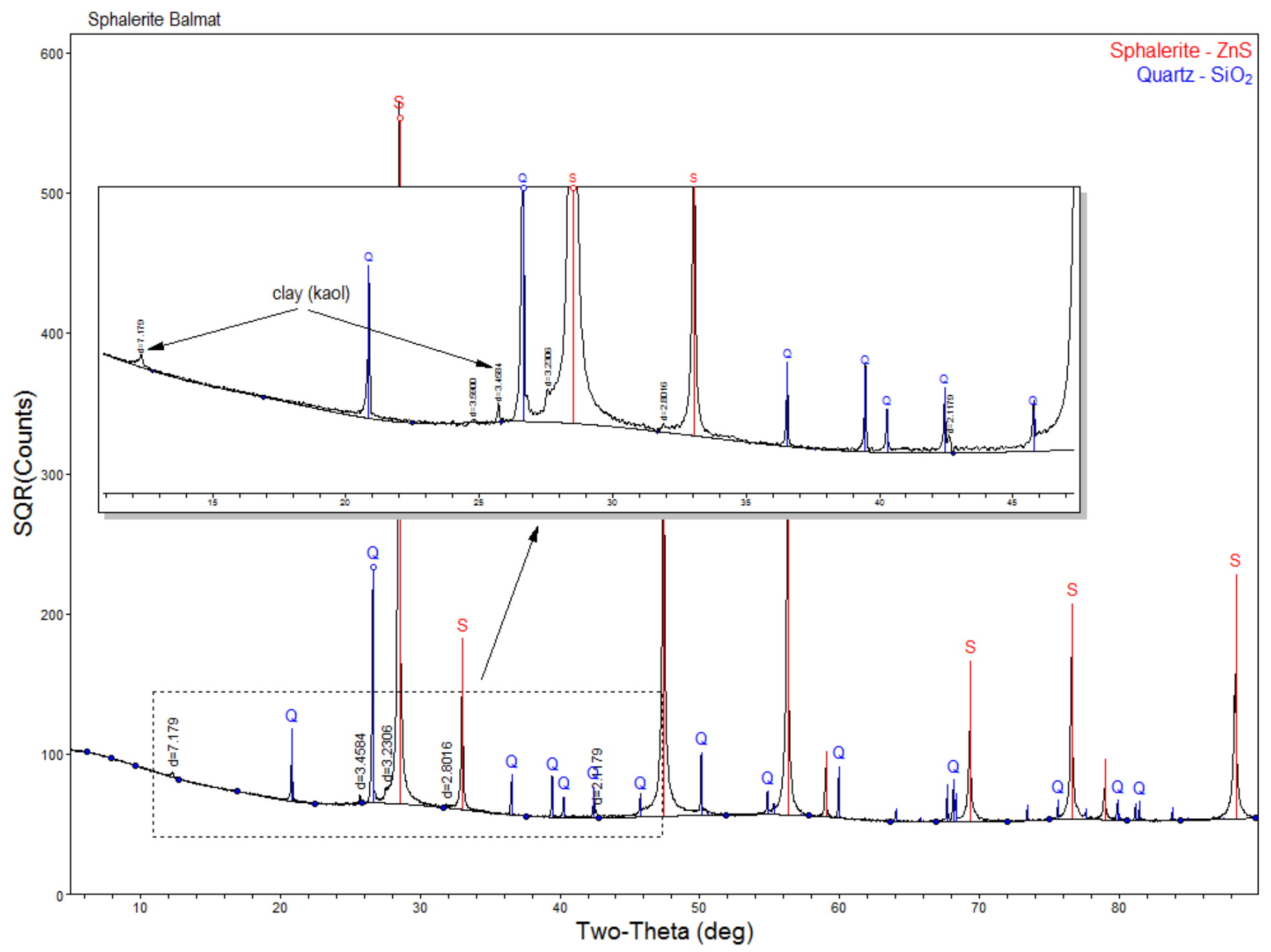

Figure 5. X-ray diffraction pattern of the Balmat, New York, sphalerite. Sphalerite and quartz are observed in the pattern as well as a $7 \AA$ (angstroms) clay that is most likely kaolinite but may be chlorite. Three other low-intensity reflections are indicated in the figure by their $\mathrm{d}$-spacing $(\hat{A})$ and represent one or more trace phases that are not identified. These reflections were evaluated by scanning electron microscope analysis, but no certain mineral identifications can be made. Q, quartz; S, sphalerite; deg, degree. 
The microprobe results for Balmat show that more than 11 percent of the zinc sites in the unit cell are substituted primarily by iron followed by trace substitutions of manganese and cadmium (table 1). The unit cell is very similar to Creede, with an axial length of $5.410 \AA$ and an axial angle of $90^{\circ}$. The 10-percent iron substitution in the zinc sites is not sufficient to cause a change in the unit-axial length to shrink the crystal volume. Studies on natural sphalerite from the International Centre for Diffraction Data and International Centre for Structure Data databases report minimum axial lengths of 5.401Å. Substitutions of metals with ionic radii larger than zinc cause expansion of the cell to larger volumes reported as high as $5.687 \AA$ in both natural and synthetic sphalerite.

\section{Carbonate Minerals-Smithsonite $\left(\mathrm{ZnCO}_{3}\right)$ and Hydrozincite $\left(\mathrm{Zn}_{5}\left(\mathrm{CO}_{3}\right)_{2}(\mathrm{OH})_{6}\right)$}

Smithsonite was originally named calamine and then renamed in the 1800 s to distinguish it from hemimorphite. Smithsonite forms in the oxidized zone of weathered zinc deposits and sometimes as a replacement of other carbonates. Metal impurities in smithsonite include $\mathrm{Fe}, \mathrm{Co}, \mathrm{Cu}, \mathrm{Mn}, \mathrm{Ca}, \mathrm{Cd}, \mathrm{Mg}$, and In. Observed zinc substitutions have been reported for the following: up to 4 percent iron, 1.5 percent calcium (but up to 9 percent has been reported from Marien Mine, Silesia, Poland), 4.8 percent copper, 7 percent manganese, 1 percent cadmium, or 1 percent magnesium. A limited solid solution exists between smithsonite and rhodochrosite (manganese end-member) and between smithsonite and siderite (iron end-member).

Smithsonite Specimen

The unit cell for smithsonite is hexagonal with carbonate groups alternating with zinc atoms (fig. 6). 


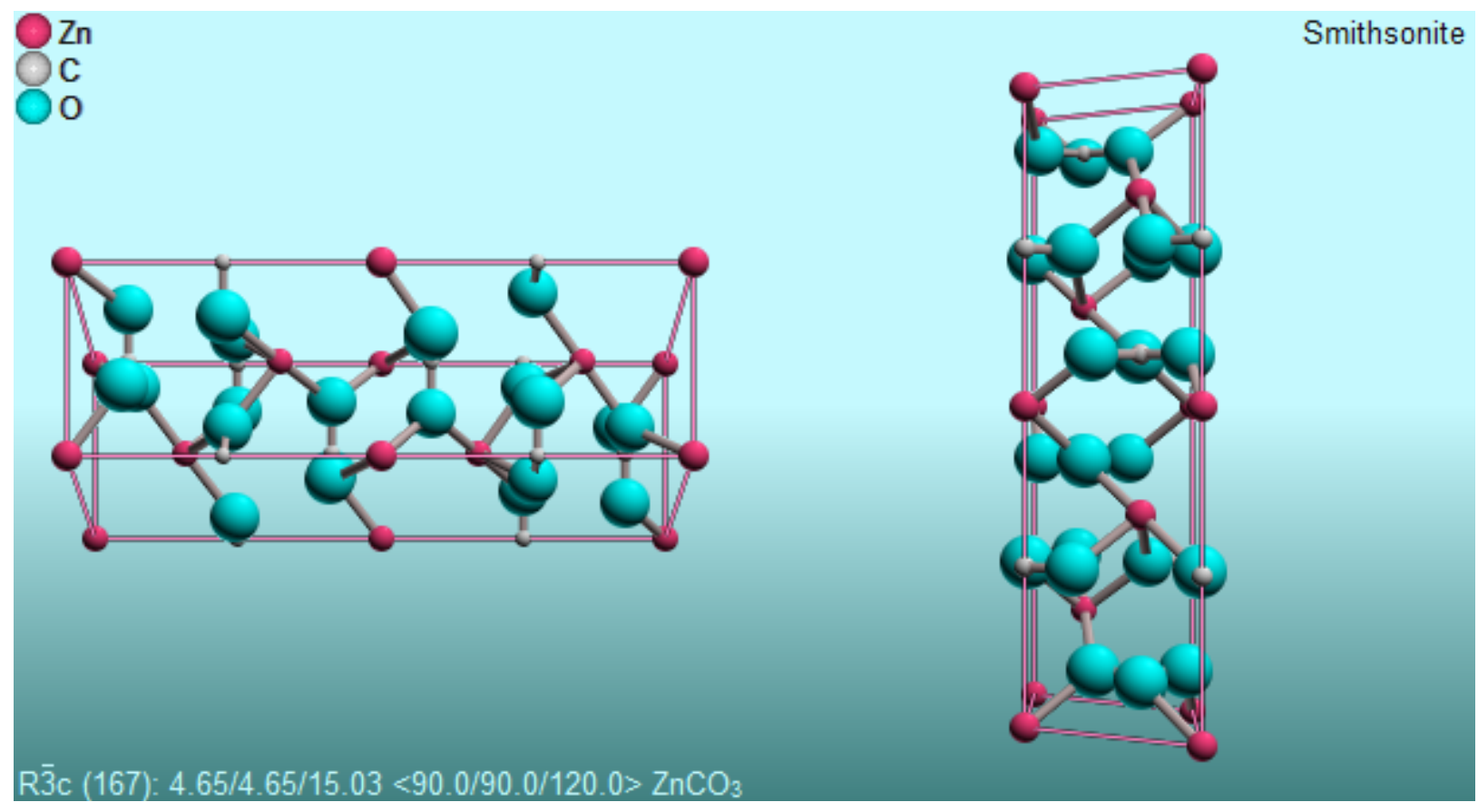

\begin{tabular}{|c|c|c|c|c|c|c|c|c|}
\hline \multirow{4}{*}{ 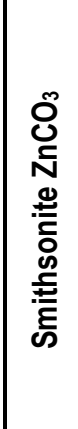 } & $\begin{array}{c}\text { Space Group } \\
\text { Trigonal - } \\
\text { Hexagonal } \\
- \\
\text { R3c }\end{array}$ & a & b & c & Alpha & Beta & Gamma & $\begin{array}{c}\text { Cell } \\
\text { Volume }\end{array}$ \\
\hline & ideal & 4.653 & 4.653 & 15.026 & 90.00 & 90.00 & 120.00 & 325.32 \\
\hline & $\begin{array}{l}\text { observed } \\
\text { range }\end{array}$ & $\begin{array}{c}\text { solid } \\
\text { solution }\end{array}$ & $\begin{array}{c}\text { solid } \\
\text { solution }\end{array}$ & $\begin{array}{c}\text { solid } \\
\text { solution }\end{array}$ & 90 & 90 & 120 & \\
\hline & measured & 4.667 & 4.667 & 15.118 & 90.00 & 90.00 & 120.00 & 329.28 \\
\hline
\end{tabular}

Figure 6. Smithsonite unit cell. Smithsonite forms a limited solid solution with rhodochrosite $\left(\mathrm{MnCO}_{3}\right)$ and siderite $\left(\mathrm{FeCO}_{3}\right)$. A wide variety of metals can substitute for zinc in the structure.

The unit cell is close to ideal, even though there is substantial calcium and cadmium substitution. The ideal unit cell for calcite is $4.99 \AA$ for a- (and b-) and $17.06 \AA$ for c-axial lengths and a cell volume of $367.8 \AA$. The carbonate framework can accommodate atoms as large as calcium with atomic radius of $0.99 \AA$; thus zinc $(0.74 \AA)$, manganese $(0.46 \AA)$, and cadmium $(0.97 \AA)$ fit readily into the structure.

Frost and others (2008) found from Raman spectroscopy studies of smithsonite that ions smaller than calcium - including cadmium, cobalt, copper, iron, magnesium, manganese, and nickel — can substitute for zinc in the structure, whereas ions with radii larger than calcium when substituted into the cell forced a transformation to aragonite group orthorhombic structure. Ions of interest that are larger than calcium include lead as well as strontium and barium.

Figure $7 A$ is a transmitted-light photomicrograph of a cross section across botryoids demonstrating the radiating crystals that form these spheroidal masses. This texture is also demonstrated in the other secondary oxidation zinc minerals. Secondary alteration zinc minerals are commonly intergrown (fig. $7 B$ ), and here smithsonite occurs 
with hemimorphite. Other accessory minerals are clinochlore and quartz as well as manganese oxides hosted along the radiating crystals (fig. $7 \mathrm{~A}$ ).

SEM studies show that the growth zones in smithsonite alternate between calcium-rich and cadmium-rich banding (figs. $7 C$ and $7 D$ ). Element-distribution maps, also known as element-intensity maps, show that zinc is homogeneously distributed (fig. $7 E$ ), but the trace metals are not. Lead mineralization is preferentially hosted in an intergrown zinc silicate, likely willemite (fig. $7 F$ ), in which crystals show lead mineralization and lead growth banding.
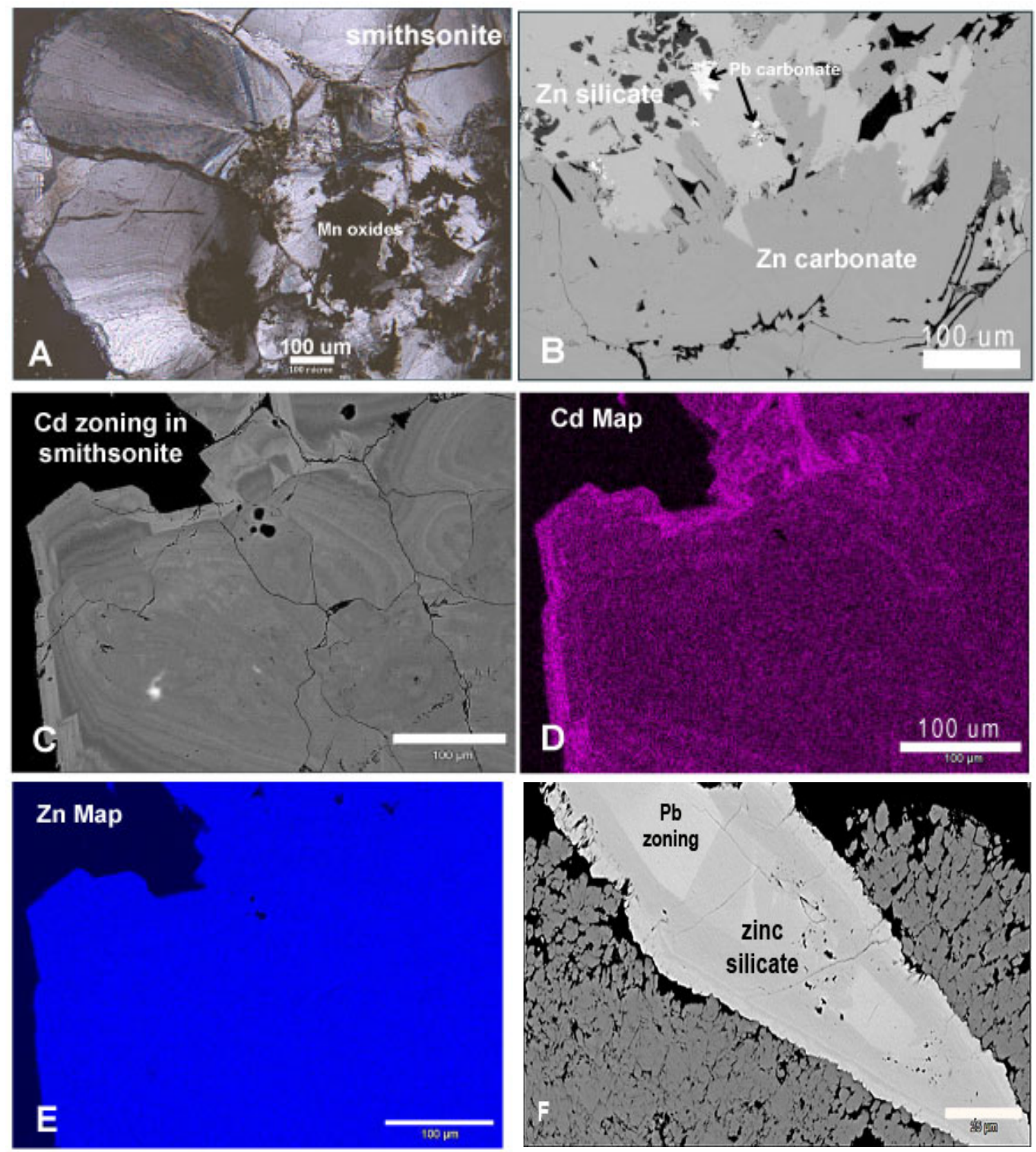

Figure 7. Smithsonite: $A$. Transmitted-light micrograph of radiating smithsonite crystals and accessory iron oxide minerals. $B$. Backscatter scanning electron image displaying intergrown smithsonite (medium gray) and hemimorphite (light gray) with accessory lead carbonate 
(bright-white areas) preferentially hosted in hemimorphite. C. Scanning electron micrograph showing element compositional zonation in smithsonite. Light-gray bands are cadmium-rich; darker bands are calcium-rich. $D$. Cadmium-element distribution map of area depicted in $C$. Light-purple bands highlight cadmium enrichment, which is concentrated in the outermost areas of late-stage crystallization. $E$. Zinc distribution map of $C$ and $D$ indicating the homogeneous distribution of zinc, which contrasts with the zoned distribution of cadmium and calcium. $F$. Backscatter scanning electron image of lead zoning in zinc silicate. Of the three intergrown zinc phases present, lead is preferentially hosted in growth zones in willemite. $\mu \mathrm{m}$, micrometer.

EPMA analysis of the specimen identified smithsonite with three levels of substitution deemed bright, medium, and dark based on backscatter brightness on the microprobe screen (table 1). The change in brightness (from bright to dark) is directly correlated to the zinc content in the smithsonite ranging from 51.55 percent zinc for the light, 50.04 percent for the medium, and 48.92 percent for the dark (table 1). Cobalt and calcium increase from light to dark, whereas lead and cadmium decrease. Based on the elemental maps above, calcium and cadmium have an inverse content relation.

An X-ray diffraction scan of the specimen shows that this specimen is primarily smithsonite (92 percent) (fig. 8). Accessory minerals include hemimorphite (7 percent), quartz $(1$ percent), willemite $(<1$ percent), and chlorite $(<1$ percent). The amorphous content calculated from the internal standard is 10 percent (table 2 ), which likely includes the manganese oxides noted in the SEM work. 


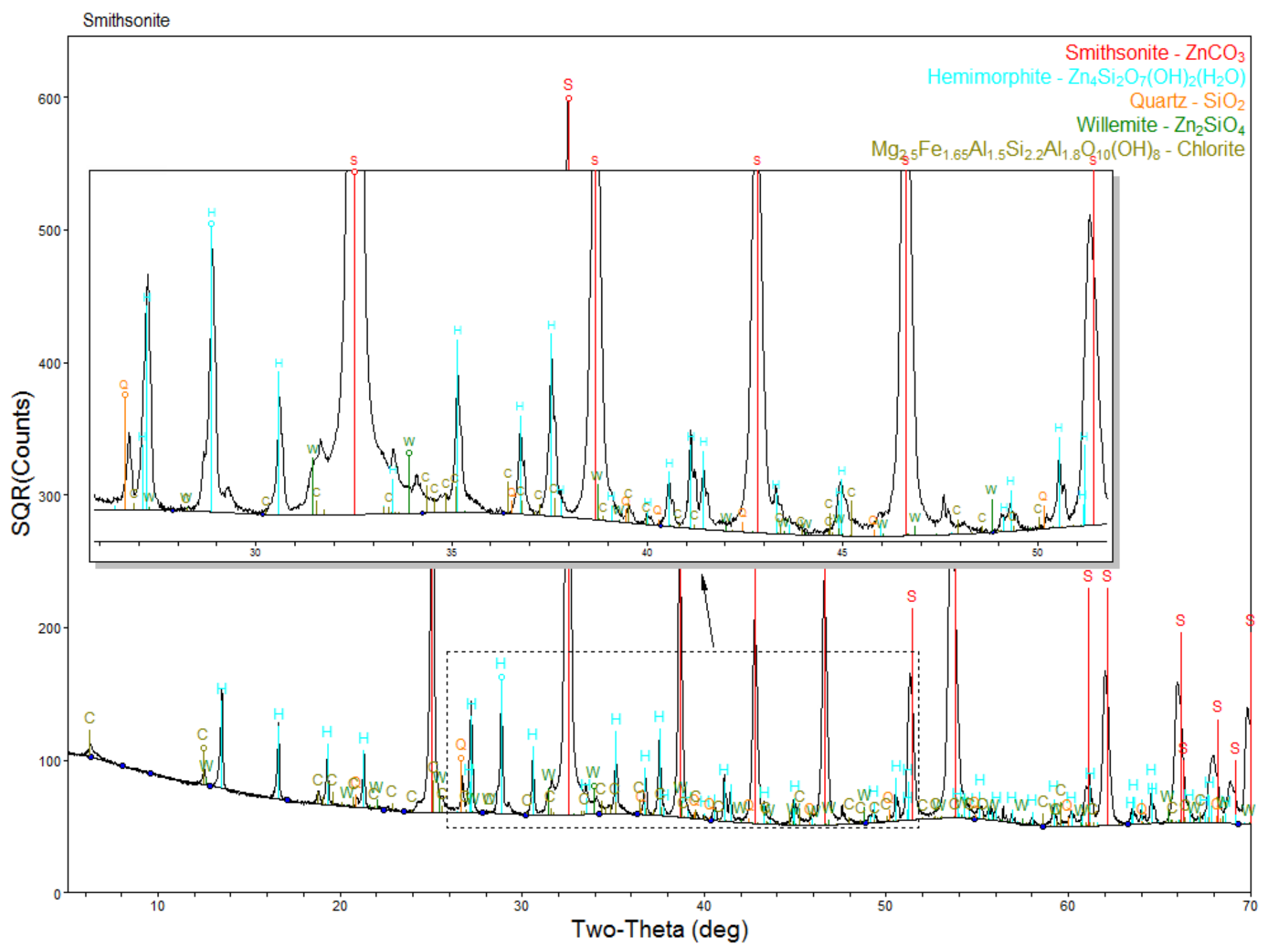

Figure 8. X-ray diffraction pattern of the smithsonite sample. Several other minerals are identified in the pattern including hemimorphite, quartz, willemite, and chlorite. The center region of the scan is expanded to show trace minerals. S, smithsonite; $\mathrm{H}$, hemimorphite; $\mathrm{Q}$, quartz; W, willemite; C, chlorite; deg, degree.

\section{Hydrozincite Specimen}

Hydrozincite forms in the oxidized zones of zinc deposits, typically an alteration of sphalerite or smithsonite. Impurities include iron, copper, lead, and cadmium. Most commonly hydrozincite occurs as massive, botryoidal, and (or) reniform incrustation on exposed zinc ore. There is a closely related mineral, brianyoungite $\left(\mathrm{Zn}_{3}\left(\mathrm{CO}_{3}, \mathrm{SO}_{4}\right)(\mathrm{OH})_{4}\right)$, which has $\left(\mathrm{SO}_{4}\right)^{2-}$ groups substituting for $\left(\mathrm{CO}_{3}\right)^{2-}$.

Recent studies have shown that hydrozincite precipitation is promoted by biological photosynthetic communities (algae and cyanobacterium) and that heavy metals are incorporated into the hydrozincite (Podda, 2000; Lattanzi, 2010a). Further studies show that the metals in the hydrozincite are bound in two ways - by direct substitution for zinc in the lattice and by forming weakly bound amorphous metal-carbonate precipitates on the surface of the mineral (Lattanzi, 2010b). Lead was found in both 
binding sites, whereas cadmium was observed only in amorphous surface precipitates on hydrozincite. These surface precipitates can easily be leached from the material and will thus release first, followed by dissolution and release of metals associated with the hydrozincite mineral.

Figure $9 A$ shows the typical radiating crystal pattern of botryoidal secondary mineralization, which commonly forms crusts on oxidized surfaces of zinc deposits. Intergrown with the hydrozincite are willemite and a cadmium-rich calcite. All three intergrown minerals were detected by XRD and SEM. These accessory minerals are not insignificant phases, and weathering of these minerals, especially the calcite, will add metals and other elements to effluent.

In addition to calcite and willemite, SEM studies revealed the presence of micronsize lead, copper, silver, and antimony phases (fig. 9B). These minerals are hosted within the porous fibrous hydrozincite, a texture that is open to fluids and oxygen. The small grain size of the accessory minerals offers a large surface area for oxidation and alteration.
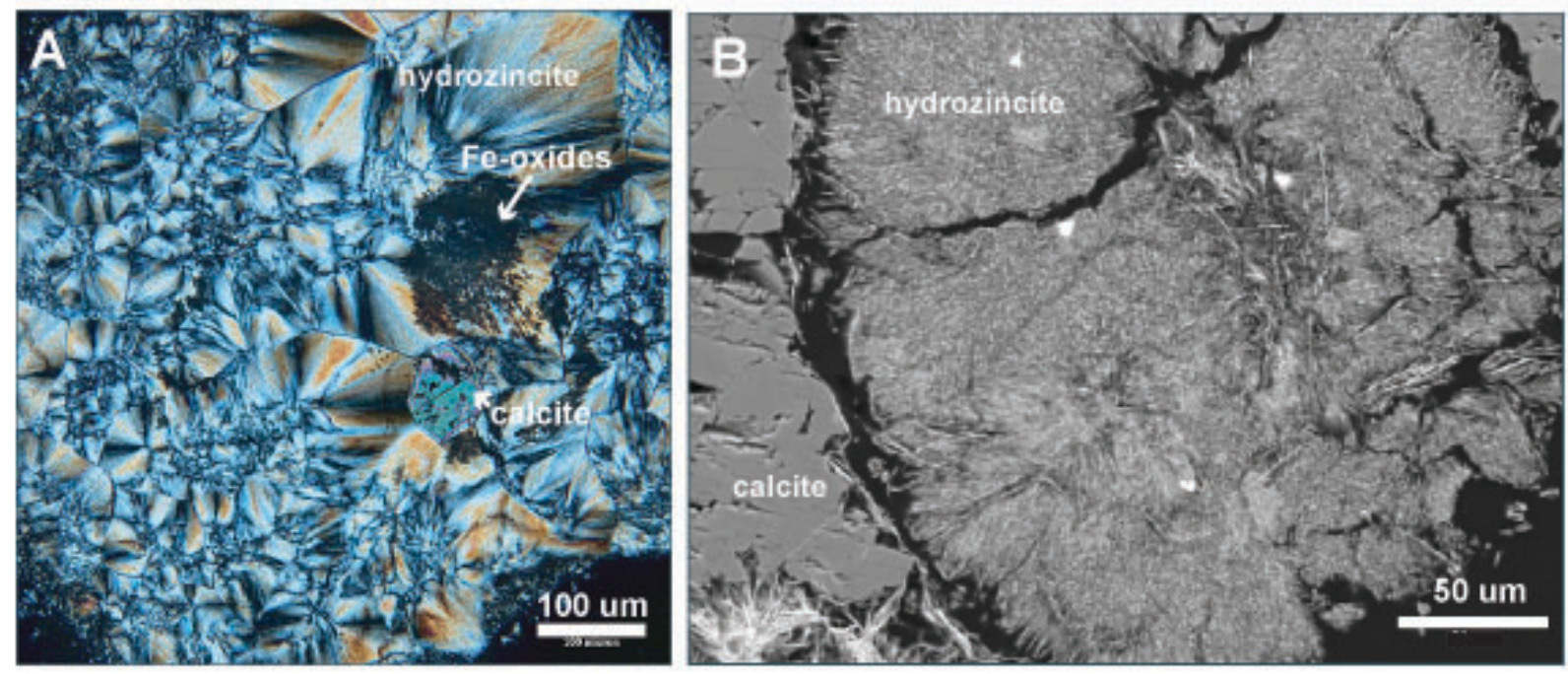

Figure 9. Hydrozincite: $A$. Transmitted-light photomicrograph showing a cross section of radiating hydrozincite crystals in botryoidal masses. $B$. Scanning electron image showing porous masses of radiating hydrozincite crystals. Hydrozincite is accompanied by calcite and accessory lead, silver, antimony, and copper minerals (bright-white spots). $\mu \mathrm{m}$, micrometer.

The XRD scan and whole-pattern fit refinement show this is another nearly pure specimen consisting of 97 percent hydrozincite, 1 percent each calcite and willemite, and $<1$ percent hematite (fig. 10). 


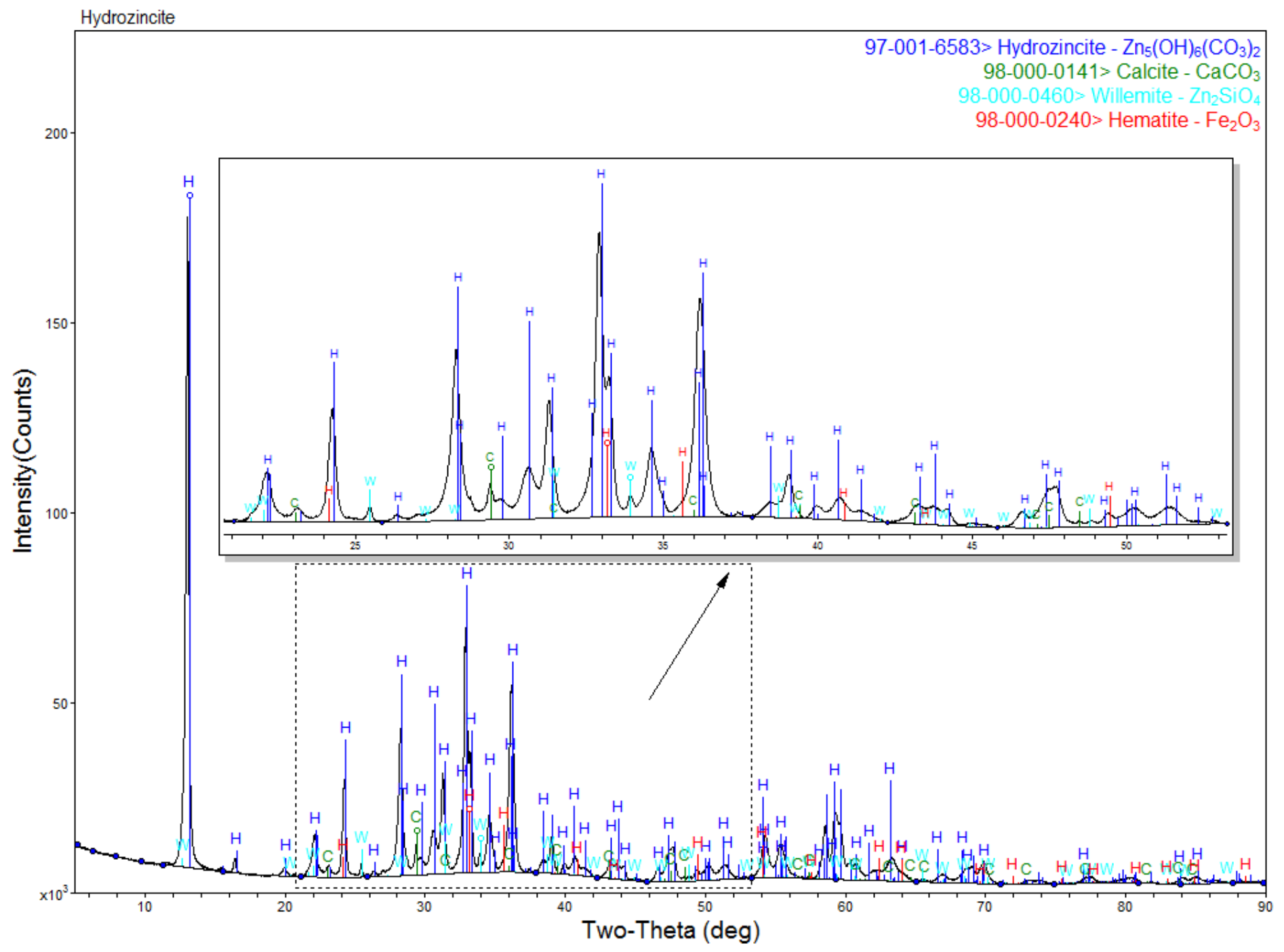

Figure 10. X-ray diffraction pattern of the hydrozincite sample. The center region of the scan is expanded to show trace phases. C, calcite; W, willemite; $\mathrm{H}$, hematite; deg, degree.

The bulk specimen may contain as much as 11 percent amorphous material, which is most likely related to the accessory minerals and alteration products of the fibrous hydrozincite (table 2). The calculated unit cell (fig. 11) is close to ideal and falls within the reported range of axial length and interaxial angles found in the mineral structure databases. 


\section{8n
Oc}
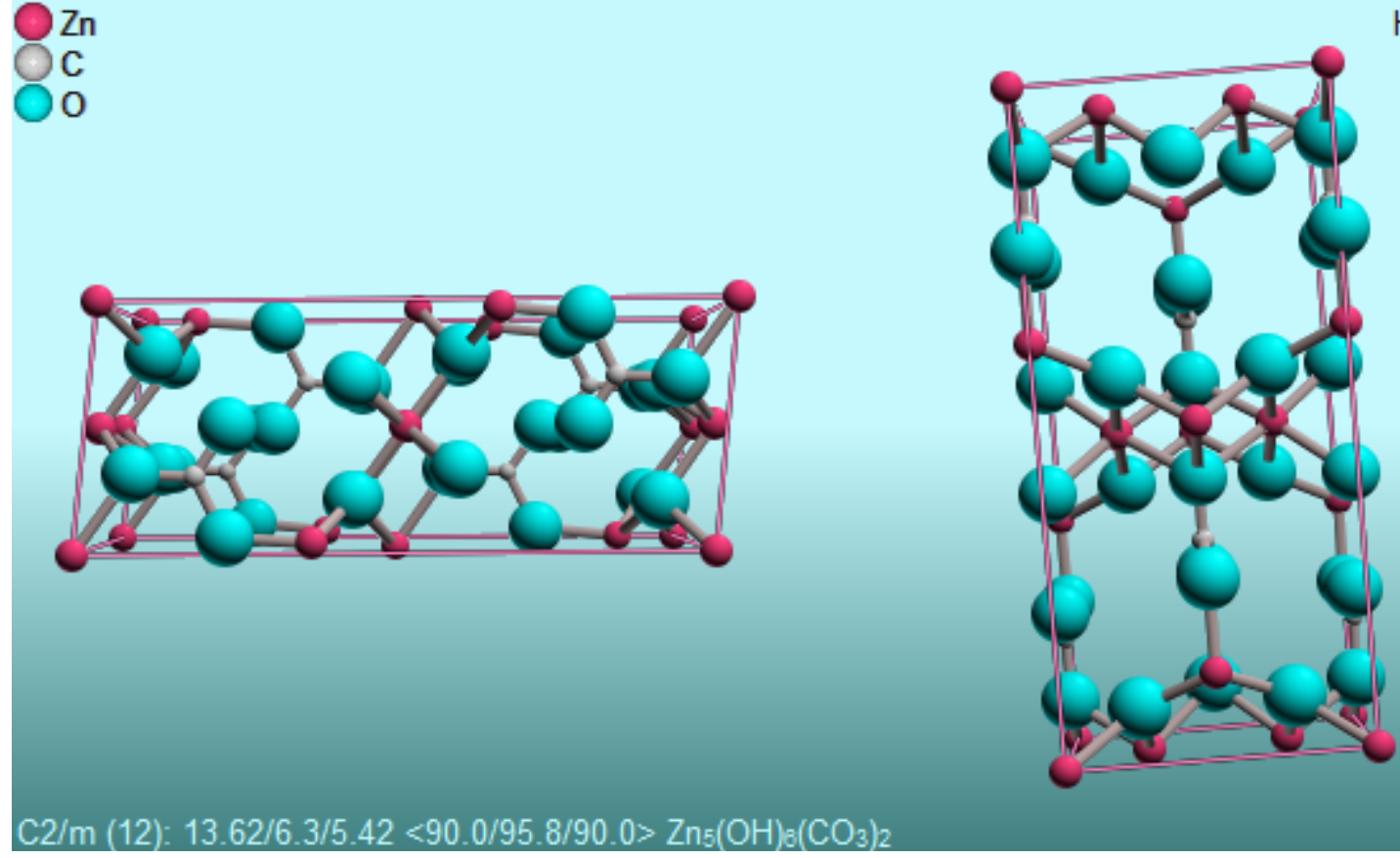

\begin{tabular}{|c|c|c|c|c|c|c|c|c|}
\hline \multirow{4}{*}{ 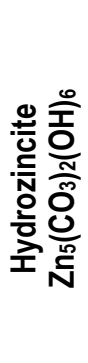 } & $\begin{array}{l}\text { Space Group } \\
\text { Monoclinic } \\
\text { C2/m }\end{array}$ & a & b & c & Alpha & Beta & Gamma & $\begin{array}{c}\text { Cell } \\
\text { Volume }\end{array}$ \\
\hline & ideal & 13.620 & 6.300 & 5.420 & 90.00 & 95.80 & 90.00 & 459.20 \\
\hline & $\begin{array}{l}\text { reported } \\
\text { range }\end{array}$ & $\begin{array}{l}13.45 \\
13.62\end{array}$ & $\begin{array}{l}6.30 \\
6.31\end{array}$ & $\begin{array}{l}5.36 \\
5.42\end{array}$ & 90.00 & $\begin{array}{l}95.30 \\
95.88\end{array}$ & 90.00 & $\begin{array}{l}454.3 \\
462.7\end{array}$ \\
\hline & measured & 13.578 & 6.298 & 5.406 & 90.00 & 95.89 & 90.00 & 462.29 \\
\hline
\end{tabular}

Figure 11. Hydrozincite unit cell is shown without the hydrogen atoms. The cell is monoclinic; zinc occurs along planes through the crystal separated by carbonate groups.

The microprobe results were inconclusive due to the fibrous open nature of the specimen. Numerous analysis lines were measured; however, the variation from line to line was substantial. Looking at the results in table 1 for hydrozincite, a group of seven analysis lines were selected and averaged. The zinc and oxygen values are extremely low compared to ideal and suggest that other minerals are present but not included in the analysis. The lead ( 1.5 percent) and copper ( 0.4 percent) noted in the SEM discussion above are present in this analysis (table 1).

\section{Silicate Minerals-Hemimorphite $\left(\mathrm{Zn}_{4} \mathrm{Si}_{2} \mathrm{O}_{7}(\mathrm{OH})_{2} \cdot \mathrm{H}_{2} \mathrm{O}\right)$ and Willemite $\left(\mathrm{Zn}_{2} \mathrm{SiO}_{4}\right)$}

Hemimorphite is a zinc silicate hydrate typically associated with smithsonite. It forms in the oxidizing zone during the weathering of zinc ores. The mineral has two distinct habits: the more common being botryoidal crusts on zinc ore and a second form of bladed crystals with doubly terminated ends.

Hemimorphite is classified as a sorosilicate, meaning it has double silica tetrahedrons, that is, two $\left(\mathrm{SiO}_{4}\right)^{4-}$ that share one oxygen making the $\left(\mathrm{Si}_{2} \mathrm{O}_{7}\right)^{6-}$ radical forming the backbone of the chain (fig. 12). 


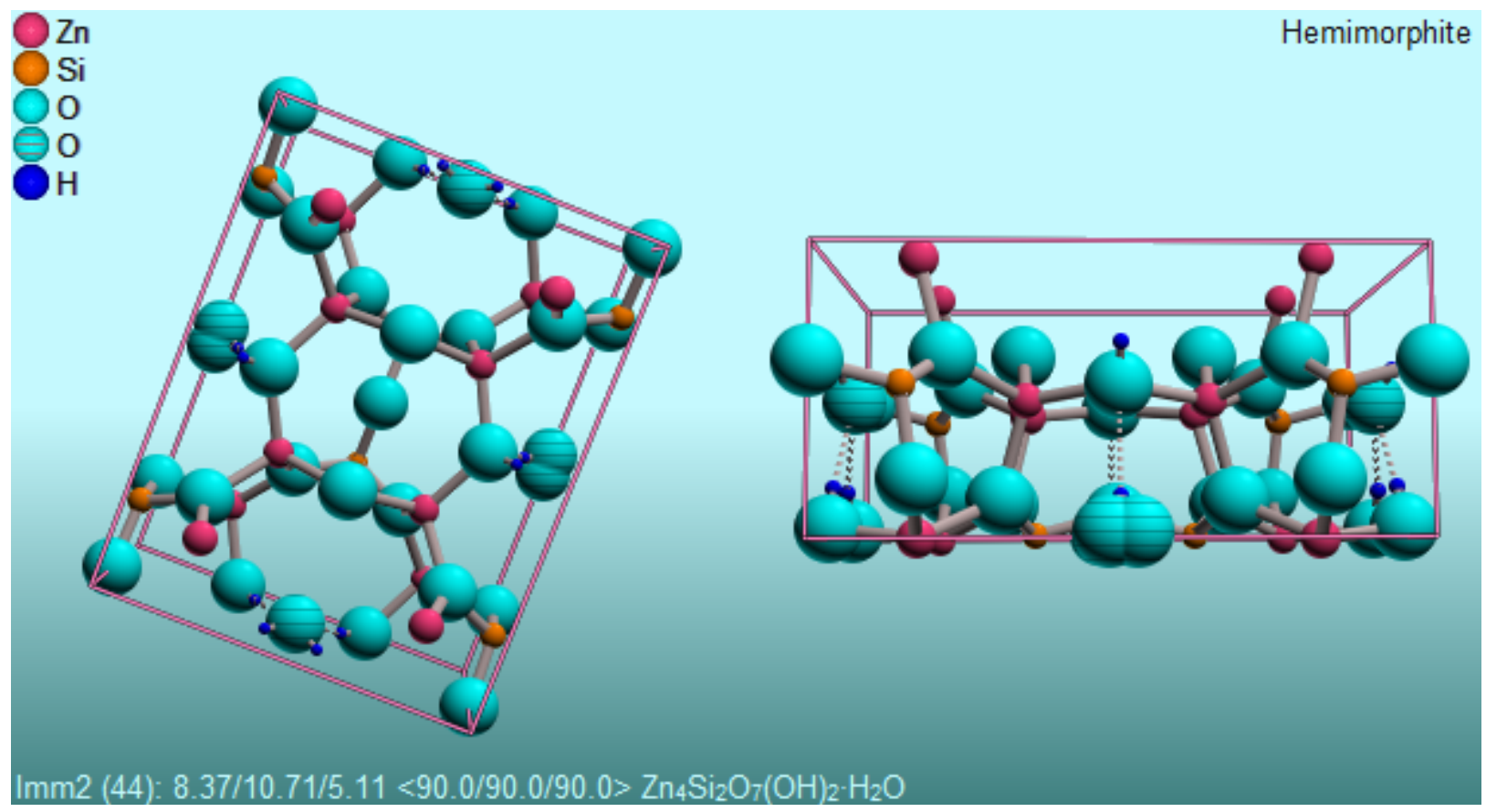

\begin{tabular}{|c|c|c|c|c|c|c|c|c|}
\hline \multirow{4}{*}{ 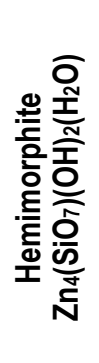 } & $\begin{array}{c}\text { Space Group } \\
\text { Orthorhombic } \\
\text { Imm2 }\end{array}$ & a & b & C & Alpha & Beta & Gamma & $\begin{array}{c}\text { Cell } \\
\text { Volume }\end{array}$ \\
\hline & ideal & 8.370 & 10.710 & 5.110 & 90.00 & 90.00 & 90.00 & 458.30 \\
\hline & observed range & $\begin{array}{l}8.366 \\
8.380\end{array}$ & $\begin{array}{l}10.700 \\
10.728\end{array}$ & $\begin{array}{l}5.110 \\
5.116\end{array}$ & 90.00 & 90.00 & 90.00 & $\begin{array}{l}458.2 \\
459.3\end{array}$ \\
\hline & measured & 8.370 & 10.722 & 5.116 & 90.00 & 90.00 & 90.00 & 459.13 \\
\hline
\end{tabular}

Figure 12. Hemimorphite unit cell; water molecules consist of cross-hatched oxygen and blue hydrogen atoms. The cell contains channels that are sufficiently large to allow metal atoms and water inside. These channel-fill metals are exchangeable.

Zinc and hydroxyl groups bond with the silicate chain to balance the charge. The silicate tetrahedra are linked by $\left(\mathrm{ZnO}_{3}(\mathrm{OH})\right)^{5-}$ to form a network that has channels running through it (Kolesov, 2006). Water and metals such as cadmium and lead can fill the channels and have been shown to be exchangeable (Mao, 2012). Weathering of hemimorphite may have an initial release of metals absorbed in the channels followed by breakdown of the network along cleavage planes (silicate tetrahedrons) releasing the metal oxides.

An anhydrous zinc silicate mineral, willemite $\left(\mathrm{Zn}_{2} \mathrm{SiO}_{4}\right)$, forms at slightly higher temperatures and pressures. Experimentally the dehydration from hemimorphite to willemite $+\mathrm{H}_{2} \mathrm{O}$ occurs near $210^{\circ} \mathrm{C}$ (Roy, 1956); however, the reaction may take place at lower temperature (near-surface conditions) in natural systems (Markham, 1960).

Zinc substitutions in the willemite structure include major to minor amounts of manganese, magnesium, iron, and copper. Zinc occupies two symmetrically distinct tetrahedra (fig. 13) that differ slightly in size. Metals, especially manganese, prefer to substitute in the larger tetrahedron (Harper and Griffen, 2005). 


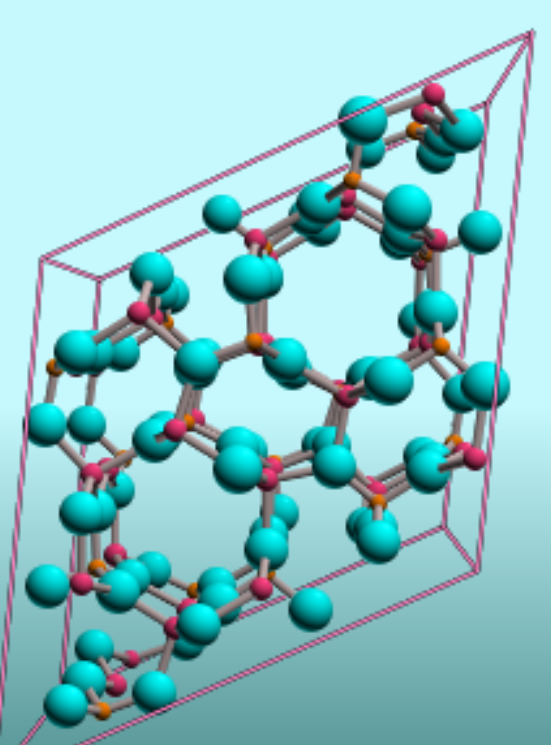

$\mathrm{R} \overline{3}(148): 13.97 / 13.97 / 9.33<90.0 / 90.0 / 120.0>\mathrm{Zn}_{2} \mathrm{SiO}_{4}$

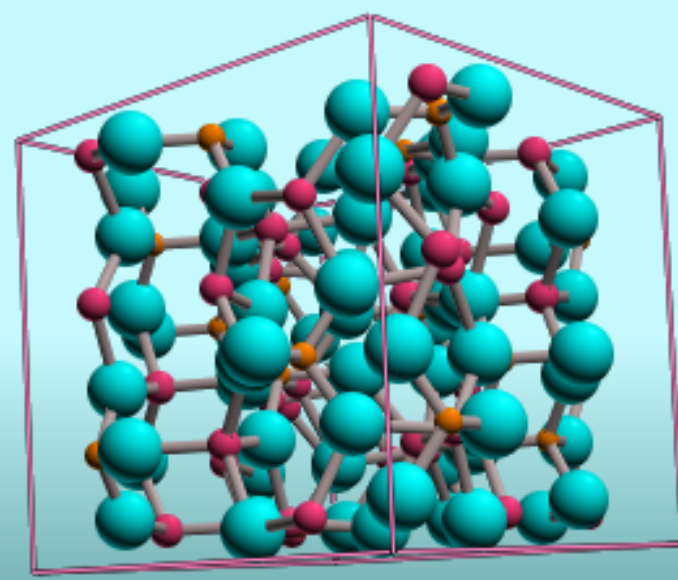

\begin{tabular}{|c|c|c|c|c|c|c|c|c|}
\hline \multirow{3}{*}{ 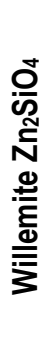 } & $\begin{array}{c}\text { Space Group } \\
\text { Trigonal - } \\
\text { Rhombohedral } \\
- \\
\text { R3 }\end{array}$ & a & b & c & Alpha & Beta & Gamma & $\begin{array}{c}\text { Cell } \\
\text { Volume }\end{array}$ \\
\hline & ideal & 13.971 & 13.971 & 9.334 & 90.00 & 90.00 & 120.00 & 1577.76 \\
\hline & measured & 13.926 & 13.926 & 9.301 & 90.00 & 90.00 & 120.00 & 1562.07 \\
\hline
\end{tabular}

Figure 13. Willemite unit cell showing the rhombohedral form. The channels formed in the structure are not large enough to allow metal atoms.

Hemimorphite/Willemite Specimen

Figure $14 A$ is a transmitted-light photomicrograph showing radiating crystal morphology, red iron oxide phases in growth zones within hemimorphite, and amorphous yellow iron phases, probably goethite, at intergrown grain contacts. Hemimorphite and willemite are intricately intergrown zinc phases (fig. 14B). Iron, manganese, and lead oxides preferentially form along partially dissolved grain boundaries (figs. $14 \mathrm{~B}$ and $14 \mathrm{C}$ ); these alteration minerals may also form as layers of botryoids. Calcite is also interstitial at grain boundaries. 

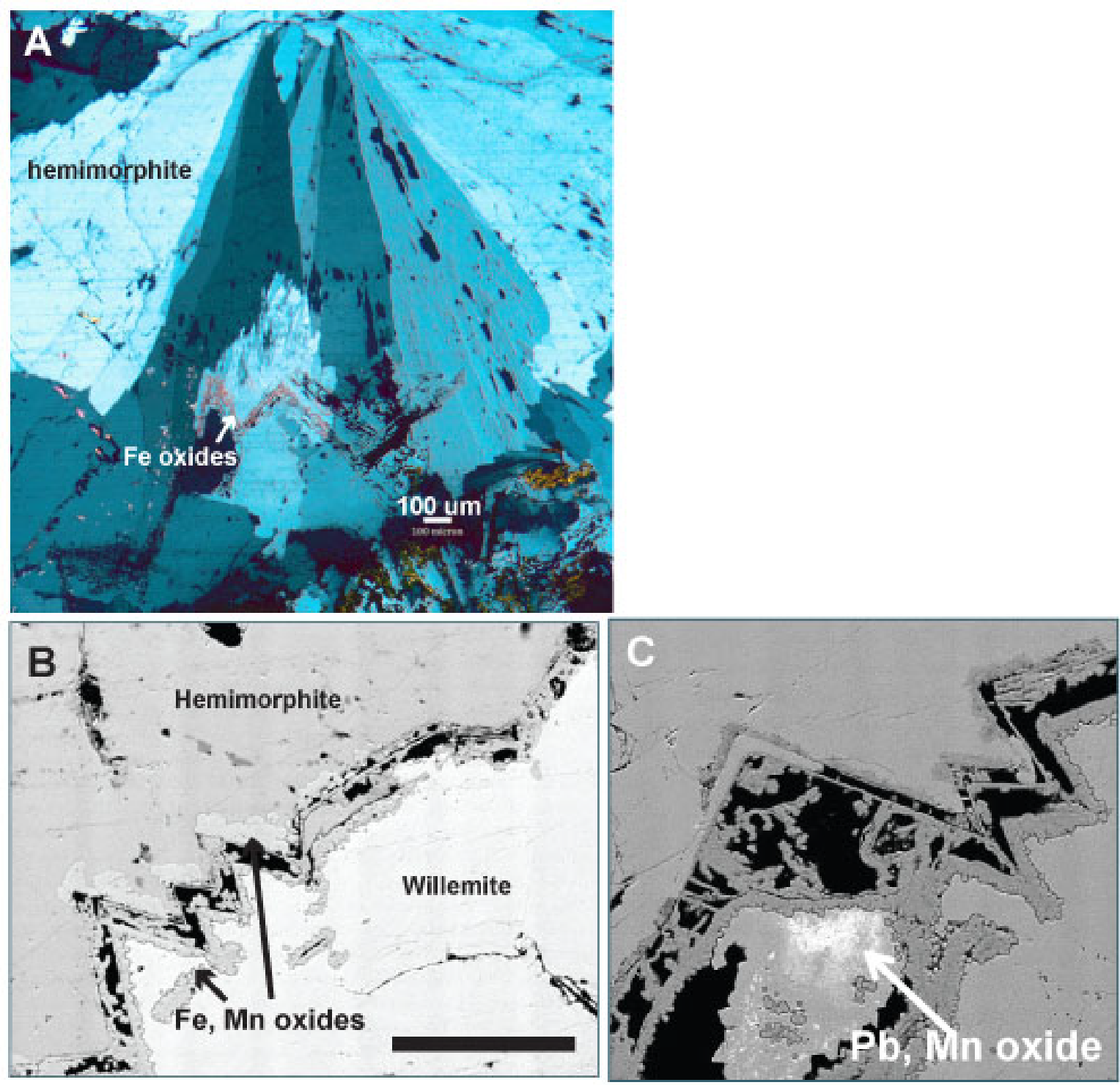

Figure 14. Hemimorphite/willemite: $A$. Transmitted-light photomicrograph of radiating hemimorphite crystals in a cross section of a botryoidal mass. $B$. Backscatter electron image of intergrown hemimorphite and willemite. Iron and manganese oxides occur along grain boundaries. $C$. Amorphous iron and manganese alteration/oxidation minerals are host to lead and other metals. $\mu \mathrm{m}$, micrometer.

Hemimorphite and willemite are orthorhombic and rhombohedral, respectively and have XRD patterns with many sets of repeating planes; that is, the patterns are busy and identification of trace components can be difficult due to interferences from the primary minerals (fig. 15). The refinement of the pattern included the following mineralogy: hemimorphite (72 percent), willemite (16 percent), calcite ( 5 percent), geothite $(4$ percent), hematite ( 3 percent), smithsonite $(<1$ percent $)$, and fluorite $(<1$ percent $)$. 


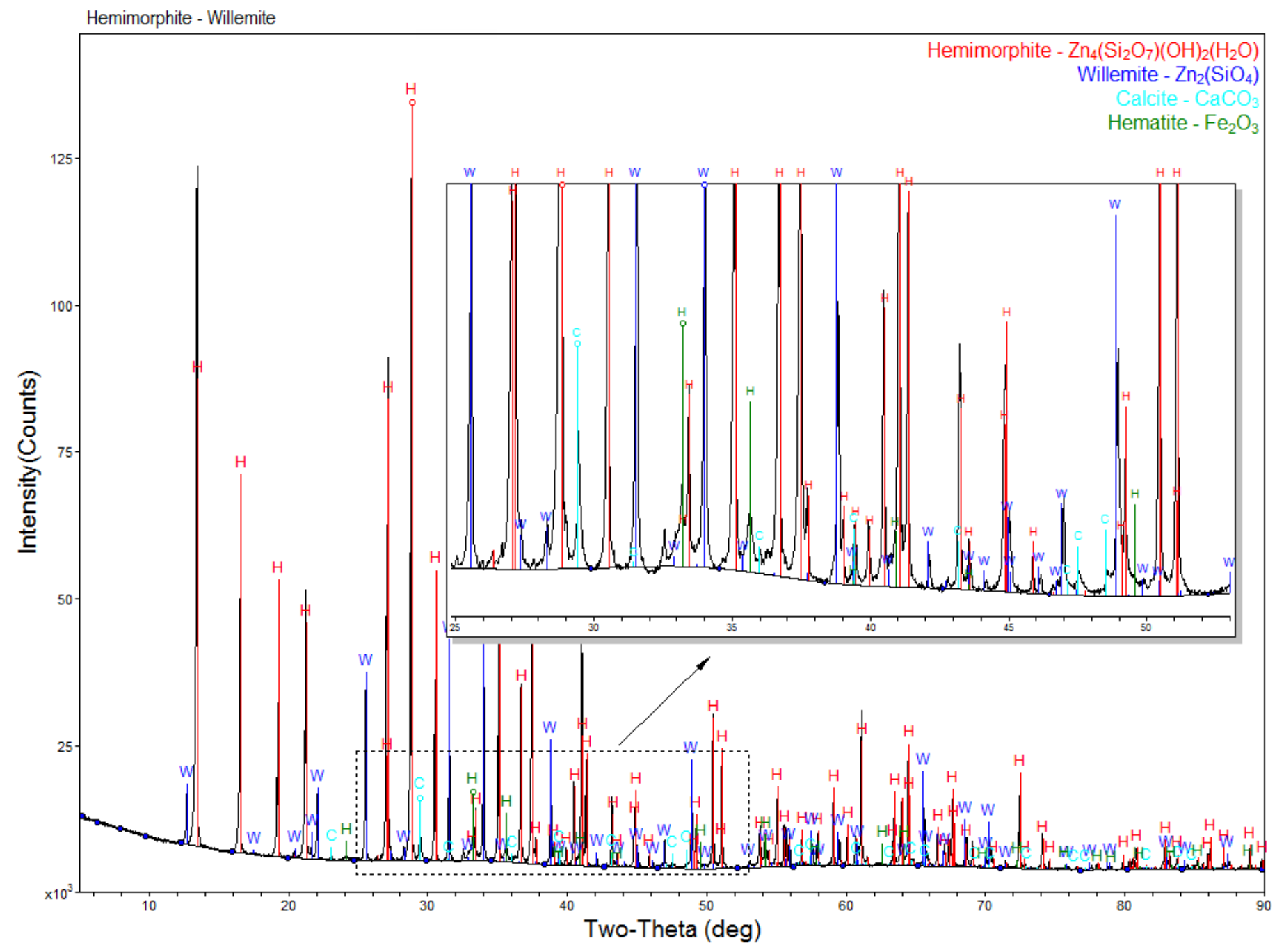

Figure 15. X-ray diffraction pattern for hemimorphite/willemite specimen. Calcite and hematite are also identified in the pattern. The center region of the scan is expanded to show trace phases. $\mathrm{H}$ (red), hemimorphite; W, willemite; C, calcite; $\mathrm{H}$ (green), hematite; deg, degree.

The bulk sample may contain as much as 13 percent amorphous component (table 2), which most likely relates to the iron, manganese, and lead oxides observed by SEM. The unit cells of both hemimorphite and willemite are close to ideal.

The microprobe results indicate that the hemimorphite is fairly pure with little substitution for the zinc in its structure; apparently the channels in this specimen are not loaded with metals or they were exchanged during the sample preparation and polishing for the analysis. The willemite in the specimen has significant manganese and minor magnesium substitution for the zinc.

\section{Summary}

Petrographic, SEM, and EMPA studies of the mode of occurrence of trace metals are important because trace metals affect the chemical and physical behavior of a mineral, especially its solubility under weathering conditions in a mine-waste pile (Diehl 
and others, 2007). Microanalytical techniques are tools for (1) identifying mineral inclusions; (2) measuring the grain size of minerals and identifying the degree of crystallinity of individual minerals, both of which are important physical properties that influence solubility; (3) recognizing preferred groupings of minerals (that is, mineral assemblages); and (4) locating mineralogic residence of minor-to-trace elements.

Scanning electron microscope and XRD studies complement one another to produce a comprehensive summary of mineralogy in a sample. Microanalytical data aids in explaining geochemical results such as element occurrence and concentration in leachate solutions. Each zinc-bearing mineral sample in this study hosts trace to minor elements; the SEM micrographs and EMPA-element maps reveal whether the trace elements are due to mineral inclusions, or whether the trace elements are distributed in the lattice structure of the mineral. Elemental chemistry detected by SEM analysis was corroborated by the bulk chemistry inductively coupled plasma-mass spectrometry analysis (discussed in the next section). XRD studies revealed strains on the crystal lattice, which may lead to increased solubility.

Pyrite was not observed by XRD in the Balmat sphalerite sample due to interferences between sphalerite and pyrite signals, and the galena is below the detection limit of the XRD instrument. Therefore, a variety of techniques are needed to identify all minerals, especially pyrite, which is a prime source of acid-rock drainage, and its presence should be recorded at any concentration. 


\section{Bulk Chemistry, Leachate Chemistry, and Acid-Base Accounting Geochemical Results for Five Zinc-Bearing Minerals}

By Philip L. Hageman

Bulk geochemistry for five zinc-bearing minerals: Appendix 2

Leachate chemistry composition: Appendix 3

\section{Introduction-Bulk Sample Chemistry}

Total element chemistry was determined for five prepared zinc-bearing mineral samples using inductively coupled plasma-mass spectrometry (ICP-MS) after a four-acid digestion method (Briggs and Meier, 2002). Mercury was determined using cold-vapor atomic fluorescence (CVAFS) (Hageman, 2007b). The zinc carbonate minerals, smithsonite and hydrozincite, were analyzed for forms of carbon; total carbon was determined by combustion using an automated carbon analyzer (Brown and Curry, 2002a); carbonate carbon was determined using coulometric titration of $\mathrm{CO}_{2}$ produced after treatment of the sample with hot $2 \mathrm{~N}$ perchloric acid (Brown and others, 2002); and organic carbon was calculated from the difference between total carbon and carbonate carbon. Total sulfur was determined using an automated sulfur analyzer. The two sphalerite samples were analyzed for total sulfur by induction furnace following the method of Brown and Curry (2002b). Complete details and references for all the methods used in this study are provided in Driscoll and others (2012). Complete bulk geochemical results are in appendix 2.

\section{Bulk Chemistry Summary}

After digestion and analysis, bulk ICP-MS results show that total zinc concentrations ranged from a high of 640,000 milligrams per kilogram $\left(\mathrm{mg} \mathrm{kg}^{-1}\right)$ in the Balmat sphalerite to a low of $380,000\left(\mathrm{mg} \mathrm{kg}^{-1}\right)$ in the hemimorphite. A graph comparing total zinc concentration for the five samples is provided in figure 16. 


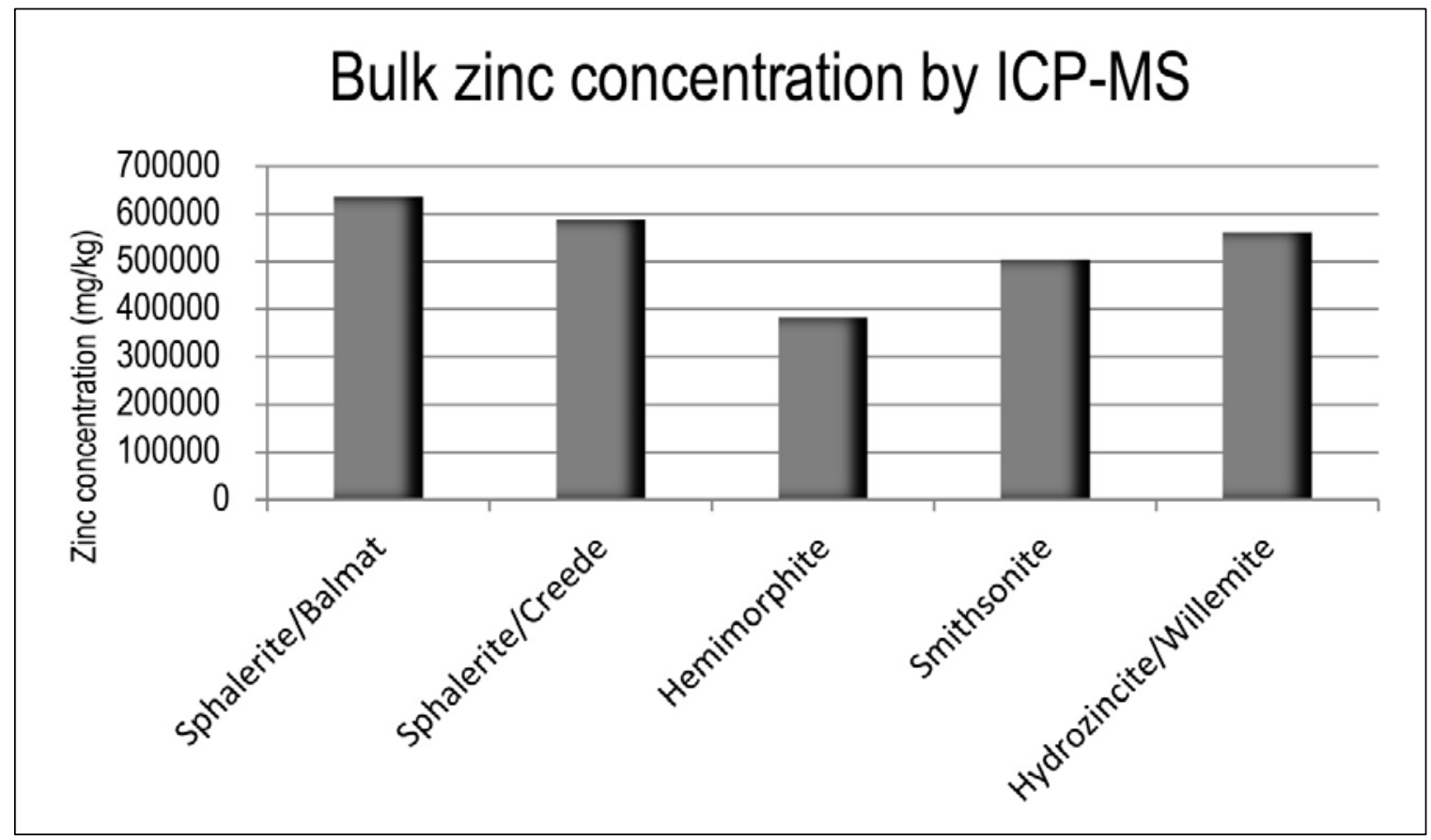

Figure 16. (Log) Bulk zinc concentration using inductively coupled plasma-mass spectrometry (ICP-MS) for five mineral samples. Mg/kg, milligrams per kilogram.

Total bulk zinc concentration fell in the following order for the five concentrated mineral samples: sphalerite $($ Balmat $)>$ sphalerite $($ Creede $)>$ hydrozincite $>$ smithsonite $>$ hemimorphite. Overall bulk geochemistry varied widely in the five samples as seen in figures 17-19, which show plots of selected major- and trace-element concentrations.

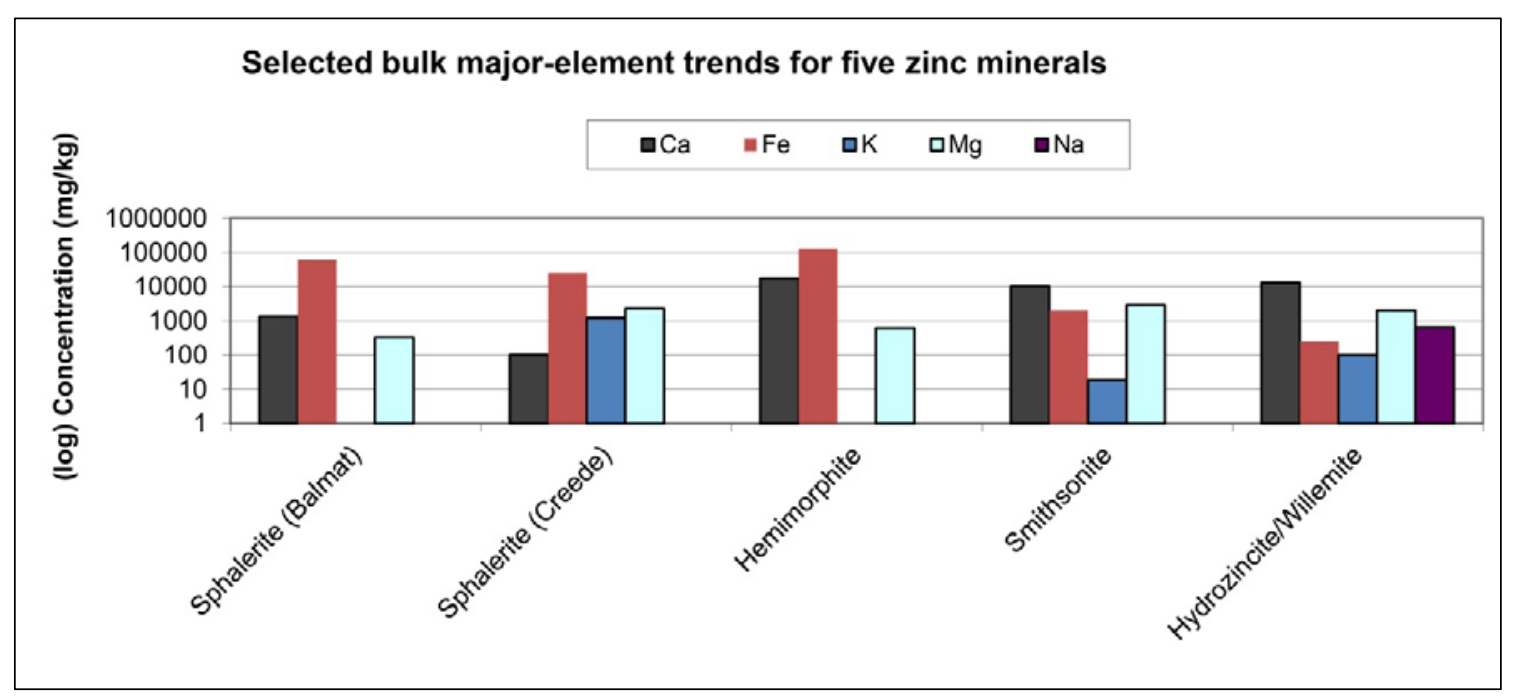

Figure 17. Bulk major-element profile_five zinc minerals. Mg/kg, milligrams per kilogram. 


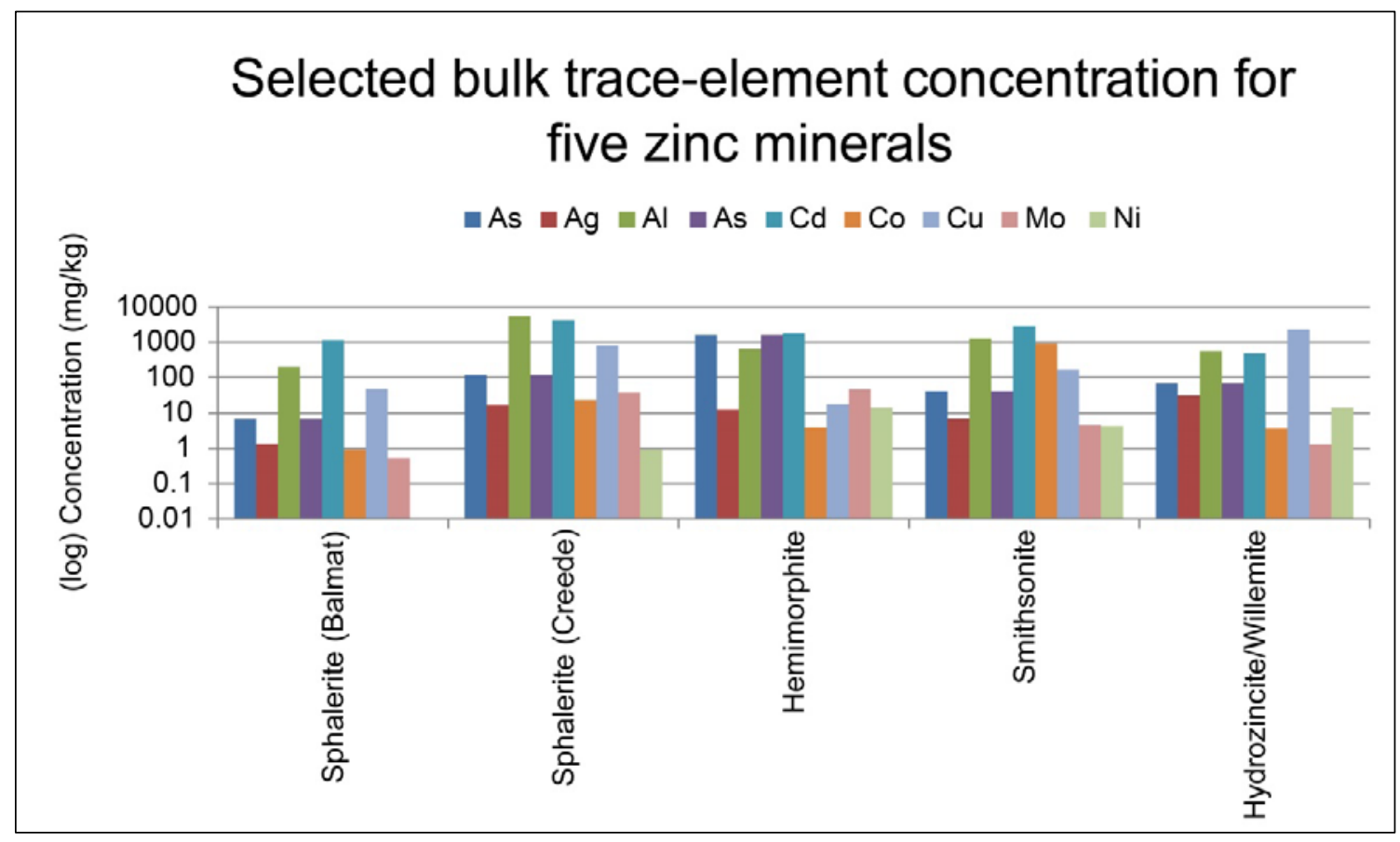

Figure 18. Bulk trace-element profile-five zinc samples. Mg/kg, milligrams per kilogram.

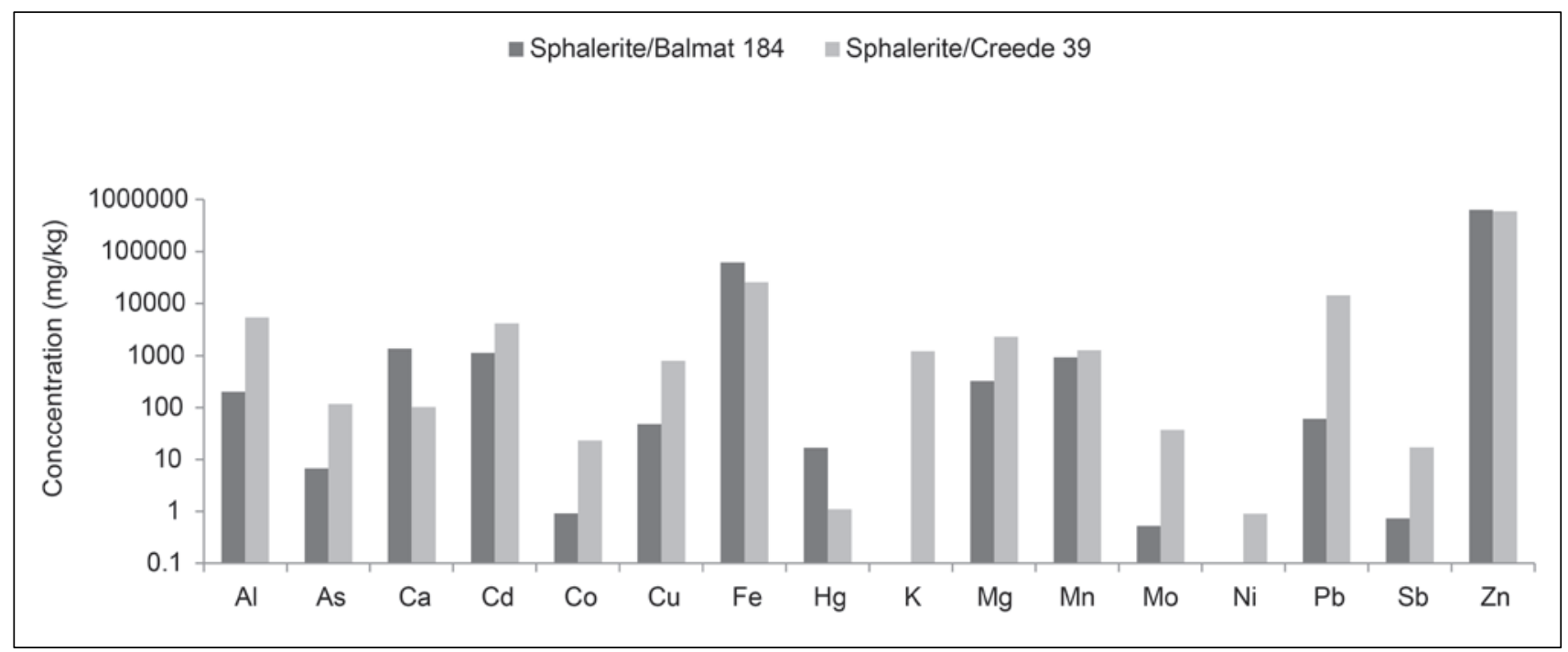

Figure 19. Comparison of selected bulk chemistry results for the Creede, Colorado, and Balmat, New York, sphalerite samples. Mg/kg, milligrams per kilogram.

\section{Comparison of Bulk Chemistry for Two Sphalerite Samples}

The two sphalerite samples have significantly different bulk geochemical composition. For many elements such as cadmium, cobalt, manganese, and lead, the sphalerite from a vein deposit at Creede, Colorado, generated higher leachate concentrations than the sphalerite from Balmat, New York, which is a sedimentary 
exhalative deposit (fig 19). As explained in the preceding section "Mineralogical Analyses" by Benzel and others, minerals from different ore-deposit types have distinct characteristics that strongly influence their geoenvironmental reactivity and metal-release potential.

Although the bulk zinc concentrations of the two sphalerite samples are nearly equivalent, abundances of some constituents vary by an order of magnitude or more (appendix 2). Documenting these differences is important because the higher bulk concentrations of potentially toxic elements such as arsenic, cadmium, copper, nickel, lead, and antimony could lead to the Creede sphalerite releasing higher concentrations of these constituents into the environment upon weathering. Complete bulk chemistry for the sphalerite samples is found in appendix 2.

\section{Introduction-Leaching Studies}

Leaching studies were conducted on prepared $(<2 \mathrm{~mm})$ splits of all five zincbearing mineral samples using five different leaching tests in order to identify and characterize constituents that are likely to be mobilized from these minerals in a variety of settings. The following is a list of the leaching tests used in this study along with a brief description of each method.

\section{U.S. Geological Survey Field Leach Test of Hageman (2007a)}

This leach test uses deionized (DI) water (ASTM Type II) and a short agitation period ( 5 minutes) to assess the readily water-soluble, water-reactive characteristics of a sample. This test is very effective in identifying the constituents that would be mobilized due to leaching by natural precipitation. An important feature of the field leach test (FLT) is that it uses a 20:1 leaching ratio (leachant/solid). This ratio avoids leachate saturation while simultaneously providing enough leachate (leach solution) to complete all the desired analyses. Use of this ratio also allows FLT-leachate geochemical results to be directly compared to the results of the EPA 1312 (synthetic precipitation leaching procedure) and 1311 (toxicity characteristic leaching procedure) methods (SPLP, TCLP; USEPA, 2004) because all three procedures use the same leaching ratio. For this study, both the 5-minute and 18-hour versions of the FLT were used. The only difference in the two procedures is the length of time samples are agitated.

\section{U.S. Environmental Protection Agency Method 1312 (Synthetic Precipitation Leaching Procedure)}

Synthetic precipitation leaching procedure (SPLP; USEPA, 2004) is a regulatory test that is used to characterize the water-soluble fraction of a sample. However, this leach test uses a long agitation period (18 hours) in order to quantify the sample constituents that would be released from samples that have been mechanically broken down by end-over-end agitation for 18 hours. Two versions of this procedure were used in this study: one using leachate adjusted to $\mathrm{pH} 4.2$ to simulate rainfall for areas east of the Mississippi River and the other using a leachate adjusted to $\mathrm{pH} 5.0$ for simulation of rainfall in areas west of the Mississippi River. 


\section{U.S. Environmental Protection Agency Method 1311 (Toxicity Characteristic Leaching Procedure)}

The toxicity characteristic leaching procedure (TCLP; USEPA, 2004) is the most commonly used regulatory leaching test. It requires end-over-end agitation for 18 hours and was designed to simulate the leaching conditions in a mixed-waste municipal landfill. The primary difference between the TCLP and the other leach tests used in this study is that the TCLP method requires the use of buffered acetic acid as the leachant. Unfortunately, this has led to the TCLP being misused (Al-Abed and others, 2005) in geochemical studies that were designed to assess or characterize the water-soluble phase of geogenic materials. Problems arise because the TCLP was not designed to accurately simulate or characterize the leaching potential of materials in the natural environment. For this reason, leachate geochemical results produced using this test are not relevant to those produced by the other leaching tests. Thus, TCLP results are included in this study for comparative purposes only.

\section{Materials, Methods, and Sample Analysis}

The samples were leached according to the specific protocols of each leach test. After leaching, $\mathrm{pH}$ and specific conductance (SC) data were determined on unfiltered aliquots of all leachates using calibrated handheld meters. Other splits of leachate were filtered using a 60 -cubic-centimeter $\left(\mathrm{cm}^{3}\right)$ plastic syringe and 0.45 -micrometer $(\mu \mathrm{m})$ pore-size, nitrocellulose-capsule filter. If filtration was difficult, a $0.70-\mu \mathrm{m}$ glass-fiber pre-filter was used in series with the $0.45-\mu \mathrm{m}$ filter. Approximately $15 \mathrm{~mL}$ of each filtrate was transferred to acid-washed high-density polyethylene (HDPE) bottles and preserved by acidification with two drops of ultra-pure nitric acid $\left(\mathrm{HNO}_{3}\right)$ for analysis using $\mathrm{ICP}-$ MS (Lamothe and others, 2002) and inductively coupled plasma-atomic emission spectrometry (ICP-AES) (Briggs, 2002). Another aliquot of filtrate (40 mL) was collected in HDPE bottles and preserved by refrigeration for determination of alkalinity (Theodorakos, 2002) and for ion chromatography (IC) analysis (Theodorakos and others, 2002). A third subsample of filtrate $(30 \mathrm{~mL})$ was collected and preserved for mercury analysis CVAFS (Hageman, 2007b). This aliquot of filtrate was collected in acid-washed borosilicate glass bottles with Teflon-lined caps and preserved with $1.0-\mathrm{mL}$ mercury-free concentrated hydrochloric acid $(\mathrm{HCl})$ and $120-\mu \mathrm{L}$ bromine chloride $(\mathrm{BrCl})$ per $30-\mathrm{mL}$ sample.

\section{Leachate Geochemistry}

Leachate analytical results for $\mathrm{pH}$, specific conductance, ICP-MS, ICP-AES, IC, alkalinity, and mercury are discussed and summarized below, and complete leachate analytical results are provided in appendix 3.

Leachate $\mathrm{pH}$

Immediately following completion of agitation, $\mathrm{pH}$ was determined on unfiltered aliquots of the leachates using a hand-held Orion $\mathrm{pH}$ meter and electrode. A comparison of the unfiltered leachate $\mathrm{pH}$ values for the five samples by all leach tests is presented in fig. 20 . 


\section{Leachate $\mathrm{pH}$ for five zinc minerals using 5 leach tests}

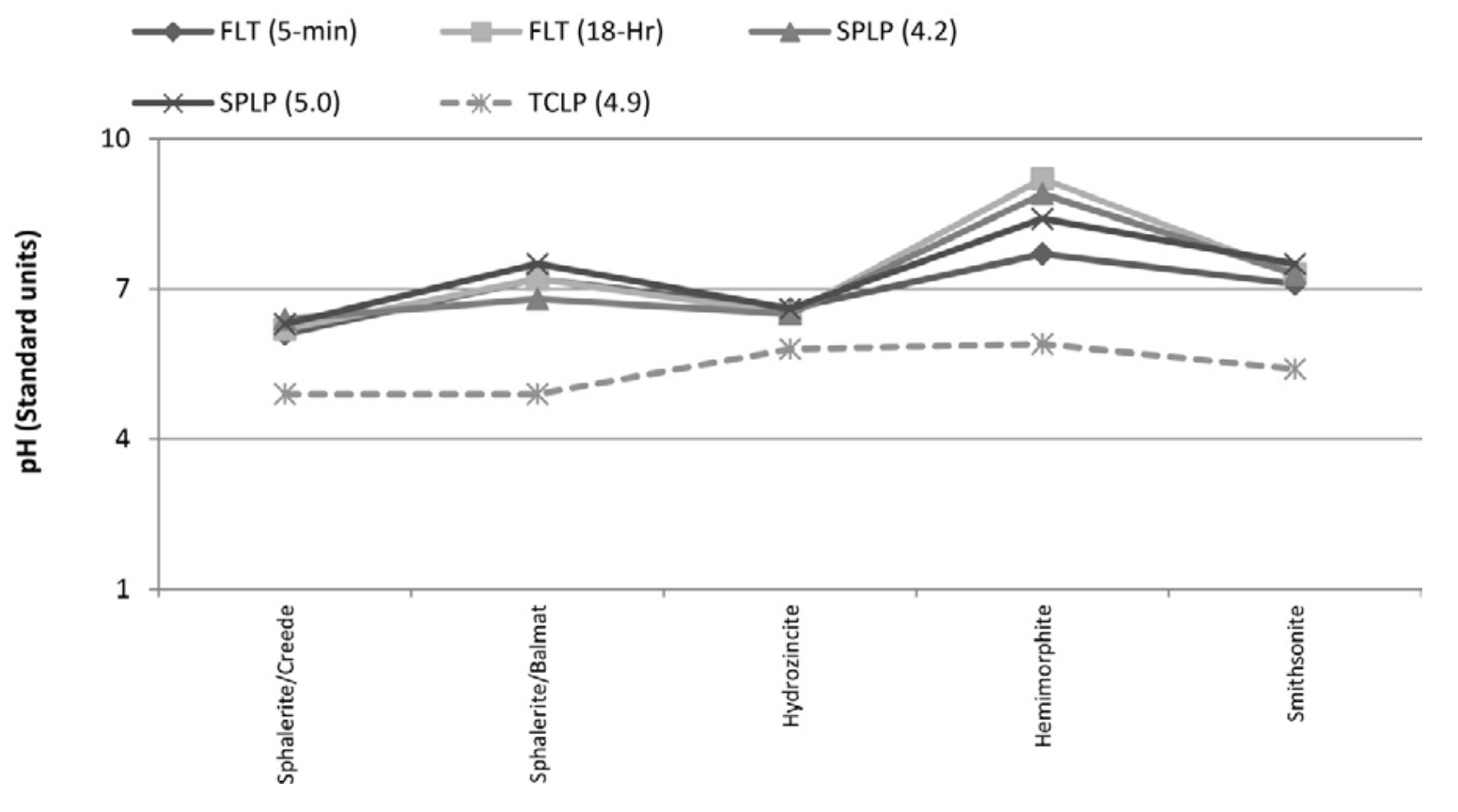

Figure 20. Leachate $\mathrm{pH}$ values for five zinc minerals using five leach tests. FLT, field leach test; SPLP, synthetic precipitation leaching procedure; TCLP, toxicity characteristic leaching procedure.

These data show that the FLT 5-minute, SPLP-pH 4.2, and SPLP-pH 5.0 leach tests all produce similar leachate $\mathrm{pH}$ trends for the samples. Importantly, the FLT 5minute leach test produced results similar to those obtained using the 18-hour leach tests. Thus, the mechanical breakdown of mineral surfaces due to extended agitation resulted in very little change to the $\mathrm{pH}$ of the leachates. The TCLP leachate $\mathrm{pH}$ values do not conform to the $\mathrm{pH}$ trends produced by the other four leach tests. It is apparent that the TCLP leachate $\mathrm{pH}$ was controlled by the acetic-acid-based extract because the $\mathrm{pH}$ values for all the samples approach the $\mathrm{pH}$ of the blank TCLP extract $(\mathrm{pH} \approx 4.95)$. This finding suggests that the TCLP leach test does not provide an accurate indication of the $\mathrm{pH}$ that would be expected when these zinc minerals weather in a natural environment.

Excluding the TCLP results, the lowest leachate $\mathrm{pH}$ (6.10) value was produced by the sphalerite sample from Creede (FLT 5 minutes). The highest leachate $\mathrm{pH}$ (9.20) value was produced by the hemimorphite sample (FLT 18 hours). After averaging the leachate $\mathrm{pH}$ values for the five mineral samples using the FLT (5 minute), FLT (18 hour), SPLP $\mathrm{pH} 4.2$, and SPLP $\mathrm{pH} 5.0$, the ordered leachate $\mathrm{pH}$ ranking (highest to lowest) among the five samples is: hemimorphite $>$ smithsonite $>$ sphalerite $($ Balmat) $>$ hydrozincite $>$ sphalerite (Creede). 
Specific conductance (SC) was measured on unfiltered aliquots of leachate using a Myron L portable conductivity meter. Figure 21 shows the leachate specific conductance results of the five zinc samples.

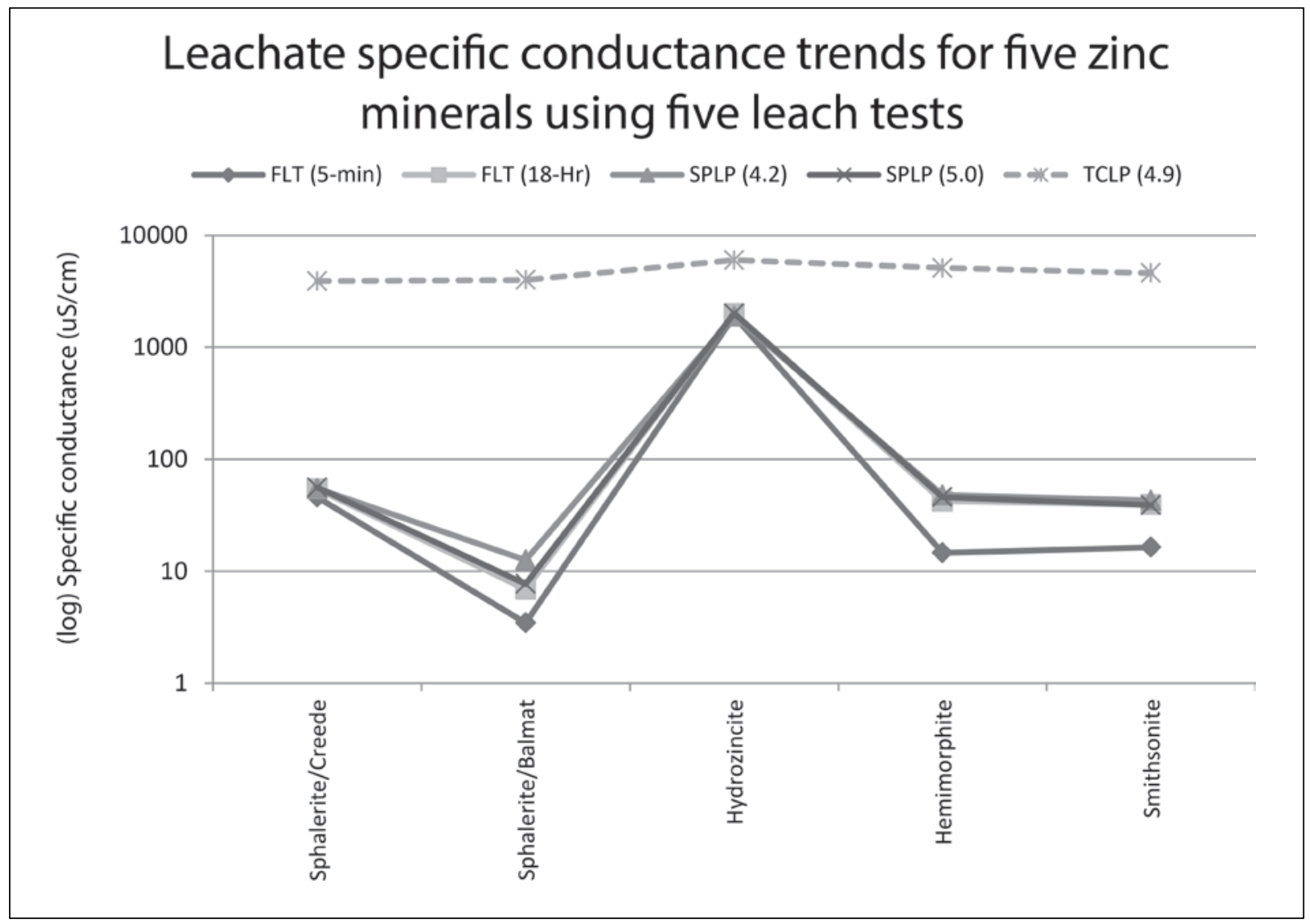

Figure 21. Leachate specific conductance (SC) values for five zinc mineral samples using five leach tests. FLT, field leach test; SPLP, synthetic precipitation leaching procedure; TCLP, toxicity characteristic leaching procedure; $\mu \mathrm{S} / \mathrm{cm}$ (microsiemens per centimeter).

Leachates produced using the FLT (5 minute and 18 hour), SPLP $\mathrm{pH} 4.2$, and SPLP pH 5.0 all provide similar SC trends for the samples. Overall, the 18-hour leaching tests produced slightly higher SC values for the sphalerite (Balmat, New York), hemimorphite, and smithsonite samples relative to the 5-minute FLT data. Four of the five zinc minerals produced leachates with relatively low leachate $\mathrm{SC}$ values of $<100$ $\mu \mathrm{S} / \mathrm{cm}$ (microsiemens per centimeter). Only the hydrozincite sample produced a much higher average leachate $\mathrm{SC}$ of $1,950 \mu \mathrm{S} / \mathrm{cm}$. Similar to leachate $\mathrm{pH}$, specific conductance in the TCLP leachates is not consistent with values derived from the other four leach tests. TCLP SC was controlled by the specific conductance of the pre-leach (blank) TCLP leach solution, which has a specific conductance of approximately $4,100 \mu \mathrm{S} / \mathrm{cm}$. Ultimately, the elevated SC of the TCLP extract solution overwhelmed soluble constituents mobilized from the samples and produced the elevated TCLP SC values. Because of this, the TCLP leach test does not provide relevant specific conductance data in terms of accurately depicting the abundances of constituents that may be solubilized 
and mobilized from these minerals as they weather and are leached in the natural environment.

After averaging the leachate SC values for all five samples obtained using the FLT (5 minute), FLT (18 hour), SPLP pH 4.2, and SPLP pH 5.0 (TCLP SC data excluded), the hydrozincite sample produced leachate with the highest average specific conductance $(1,950 \mu \mathrm{S} / \mathrm{cm})$. The ordered average SC ranking (highest to lowest) is as follows: hydrozincite $>$ sphalerite $($ Creede $)>$ hemimorphite $>$ smithsonite $>$ sphalerite (Balmat).

\section{Major Anions by lon Chromatography}

Leachates from all five leach tests were analyzed for chloride, fluoride, and nitrate $\left(\mathrm{NO}_{3}\right)$ using ion chromatography (IC) (Theodorakos and others, 2002). Data from all tests except the TCLP indicate that all of the minerals have relatively low anion concentrations (appendix 3). TCLP leachates have fluorine concentrations that are abnormally highorders of magnitude in some cases - relative to those produced by the other tests.

\section{Alkalinity}

All of the leachates were analyzed for alkalinity using the method described in Theodorakos (2002). Alkalinity values were relatively low for all of the samples by all of the leach tests except those produced by the TCLP (appendix 3). TCLP leachates indicate much higher (in some cases by several orders of magnitude) alkalinity for all the samples relative to those produced by the other leach tests.

\section{Leachable Zinc and Other Metallic Elements}

An important aspect of this study involved assessing, quantifying, and characterizing the potential for these minerals to release zinc either in the surficial environment via weathering (leaching) or in the subsurface as a result of groundwater moving through mineralized rocks.

The extent to which zinc was leached from the various samples as a function of the five leach protocols varies significantly. In figures 22-26, the zinc leachate concentrations are provided in milligrams leached per kilogram of sample $(\mathrm{mg} / \mathrm{kg})$. This was done in order to compare the leachate results given in micrograms per liter $(\mu \mathrm{g} / \mathrm{L})$ to those of the bulk zinc concentration data given as $\mathrm{mg} / \mathrm{kg}$. In order to convert the data, leachate zinc concentration $(\mu \mathrm{g} / \mathrm{L})$ was multiplied by the leaching dilution factor (twenty), and the resulting value was divided by one thousand to convert units. Zinc concentrations for SPLP ( $\mathrm{pH}$ 5.0) leachates for the sphalerite (Creede) and the hydrozincite sample were not reported due to ICP-MS instrument problems. 


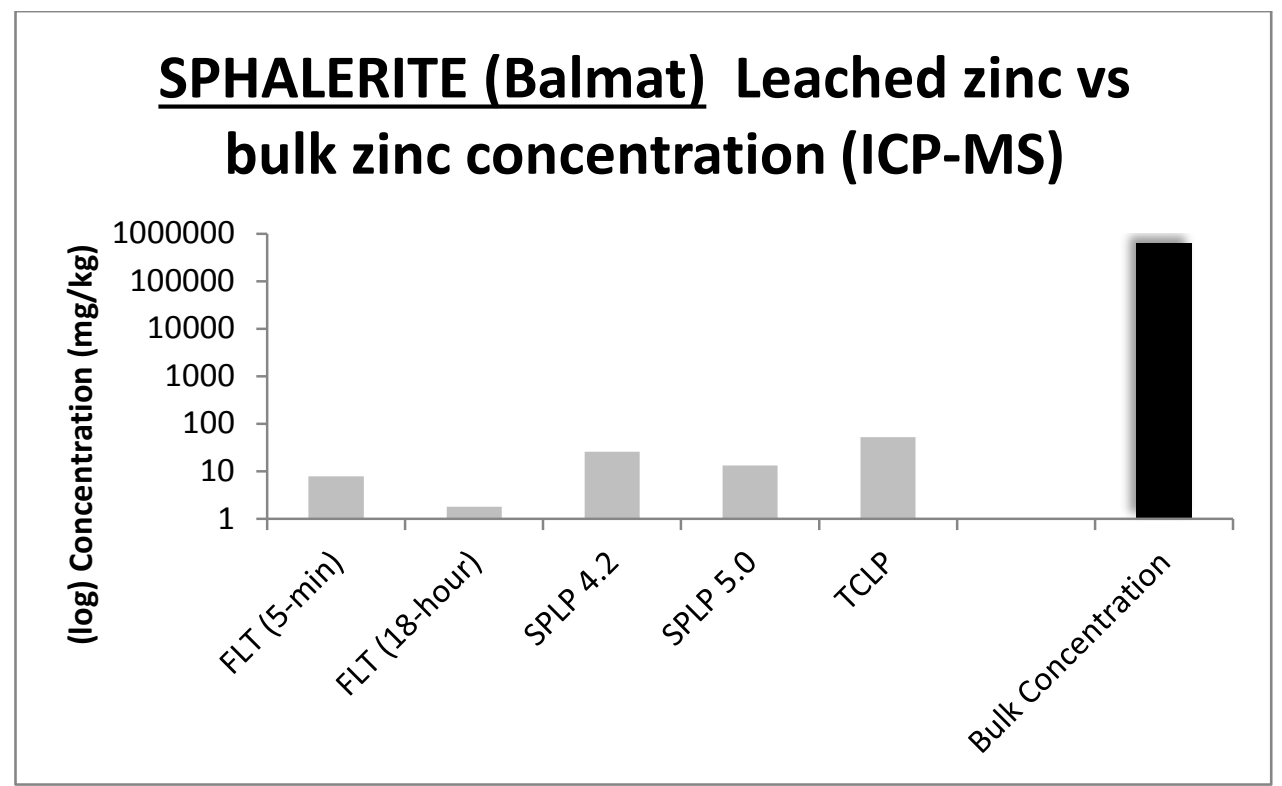

Figure 22. Zinc results for sphalerite (Balmat, New York). ICP-MS, inductively coupled plasmamass spectrometry; mg/kg, milligrams per kilogram; FLT, field leach test; SPLP, synthetic precipitation leaching procedure; TCLP, toxicity characteristic leaching procedure.

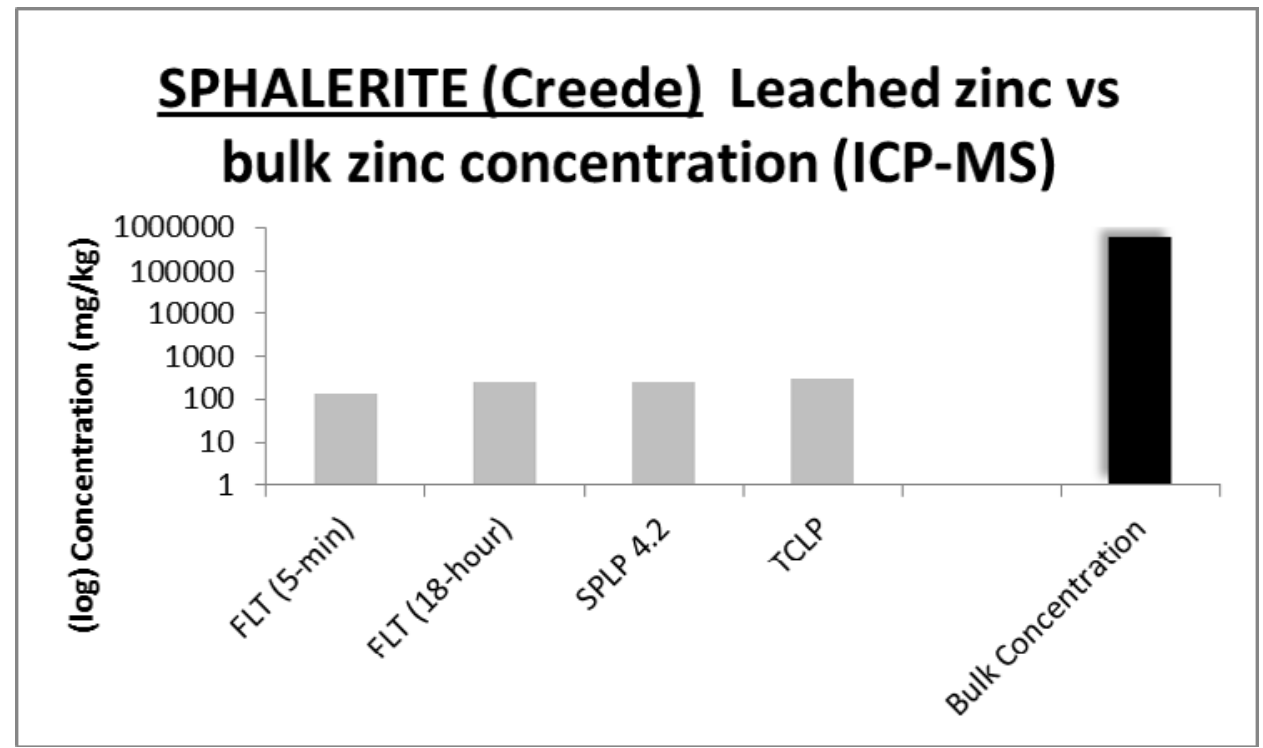

Figure 23. Zinc results for sphalerite (Creede). ICP-MS, inductively coupled plasma-mass spectrometry; mg/kg, milligrams per kilogram; FLT, field leach test; SPLP, synthetic precipitation leaching procedure; TCLP, toxicity characteristic leaching procedure. 


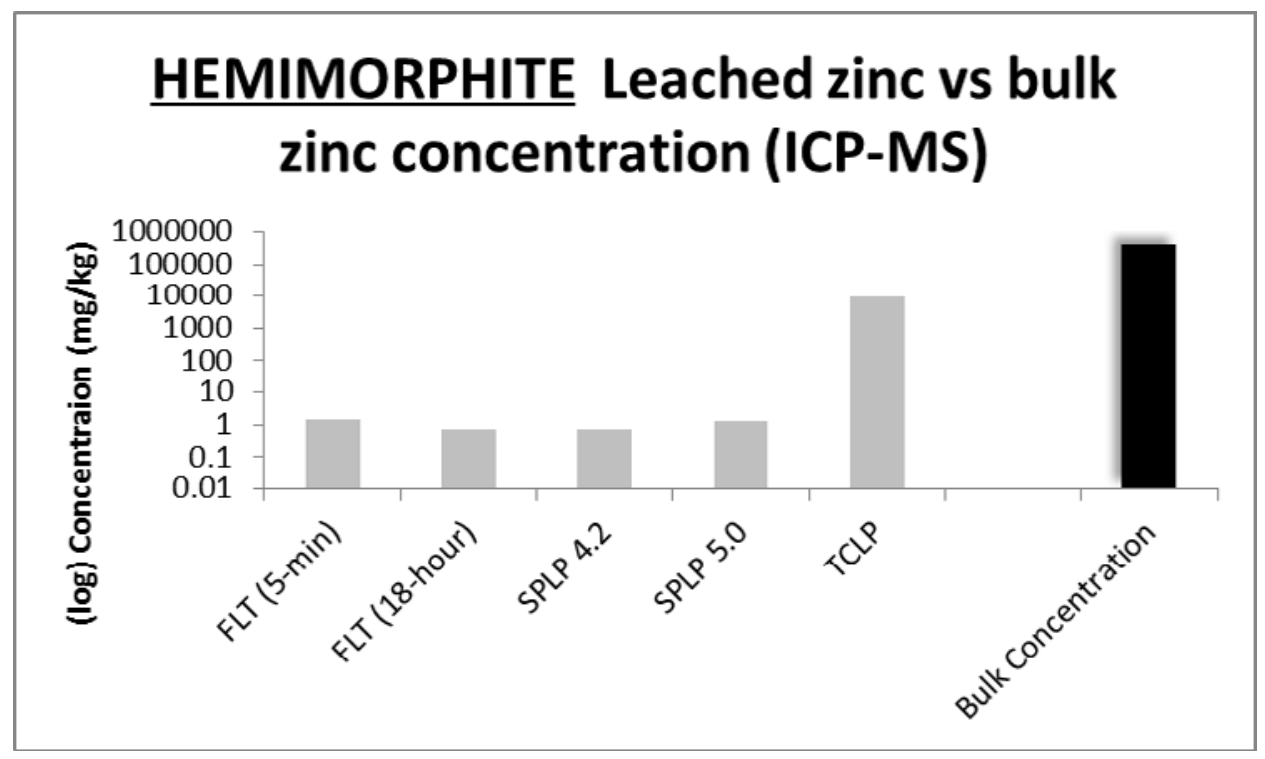

Figure 24. Zinc results for hemimorphite. ICP-MS, inductively coupled plasma-mass spectrometry; mg/kg, milligrams per kilogram; FLT, field leach test; SPLP, synthetic precipitation leaching procedure; TCLP, toxicity characteristic leaching procedure.

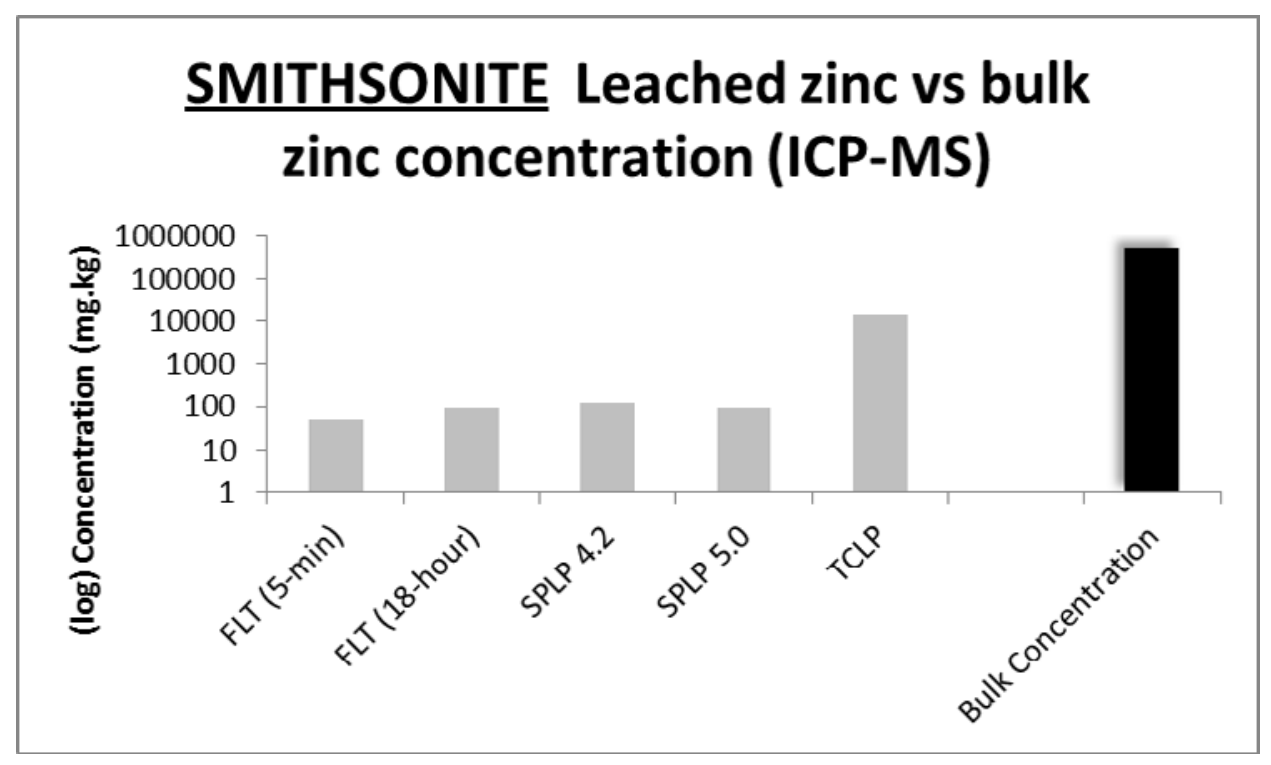

Figure 25. Zinc results for smithsonite. ICP-MS, inductively coupled plasma-mass spectrometry; $\mathrm{mg} / \mathrm{kg}$, milligrams per kilogram; FLT, field leach test; SPLP, synthetic precipitation leaching procedure; TCLP, toxicity characteristic leaching procedure. 


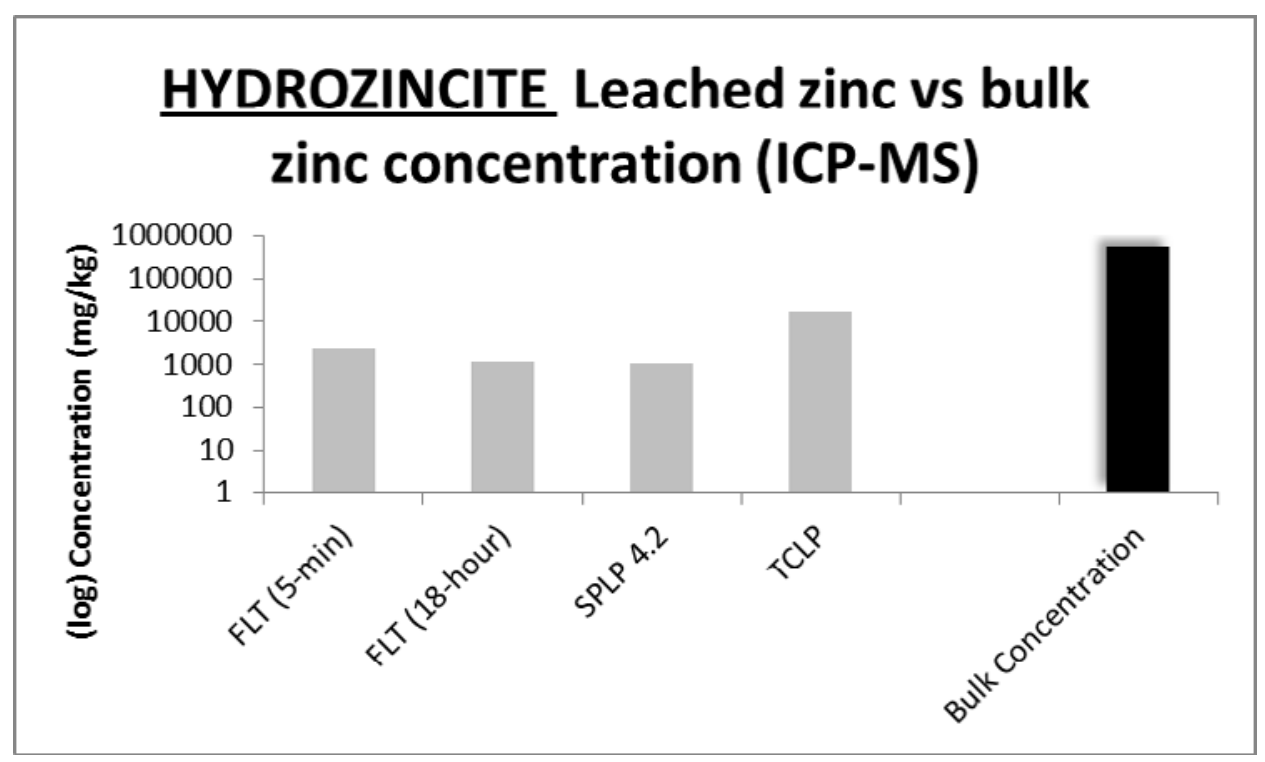

Figure 26. Zinc results for hydrozincite. ICP-MS, inductively coupled plasma-mass spectrometry; $\mathrm{mg} / \mathrm{kg}$, milligrams per kilogram; FLT, field leach test; SPLP, synthetic precipitation leaching procedure; TCLP, toxicity characteristic leaching procedure.

Comparison of the leachate zinc data highlights the fact that leachates produced using the TCLP leach test contain elevated zinc concentrations relative to those produced by the other leach tests. For three of the samples, the difference was dramatic with TCLP zinc concentrations nearly two orders of magnitude greater for the hemimorphite and smithsonite samples and nearly one order of magnitude greater for the hydrozincite sample. Use of the TCLP leach protocol to characterize the leachability of zinc minerals yields results that are misleading and overestimate the amount of zinc that will be leached and mobilized.

Excluding the TCLP data, results for the other four leach tests indicate that, on average, the hydrozincite sample released the most zinc, whereas the hemimorphite released the least. For all five minerals, the zinc leached was $<1$ percent of the bulk zinc concentration. The relatively minimal zinc release is likely due to the samples having "fresh" surfaces, which have not been subjected to extensive oxidation or formation of soluble secondary zinc salts that can enhance metal release.

Comparison of leachable zinc from the two sphalerite samples suggest that although the Balmat sphalerite had generally higher bulk concentrations of metallic elements including zinc, the Creede sphalerite released considerably more zinc and other metallic elements to solution than the Balmat sphalerite. Mineralogical studies conducted by Benzel and Diehl (this volume) show that the Balmat sphalerite is composed predominantly of sphalerite and quartz and is therefore somewhat less reactive, whereas the sample from Creede is a vein-filling cement in a breccia of quartz-orthoclase host rock and alteration minerals that enhance its reactivity.

The intergrown hydrozincite and willemite sample releases especially elevated concentrations of $\mathrm{As}, \mathrm{Cd}, \mathrm{Cu}$, and $\mathrm{Pb}$. The sample composed of hydrozincite and willemite is the most fibrous and porous of those studied and is therefore most susceptible to alteration by fluids and oxygen. An example of the leachate geochemical signature for selected metallic elements produced using the FLT is shown in figure 27. 


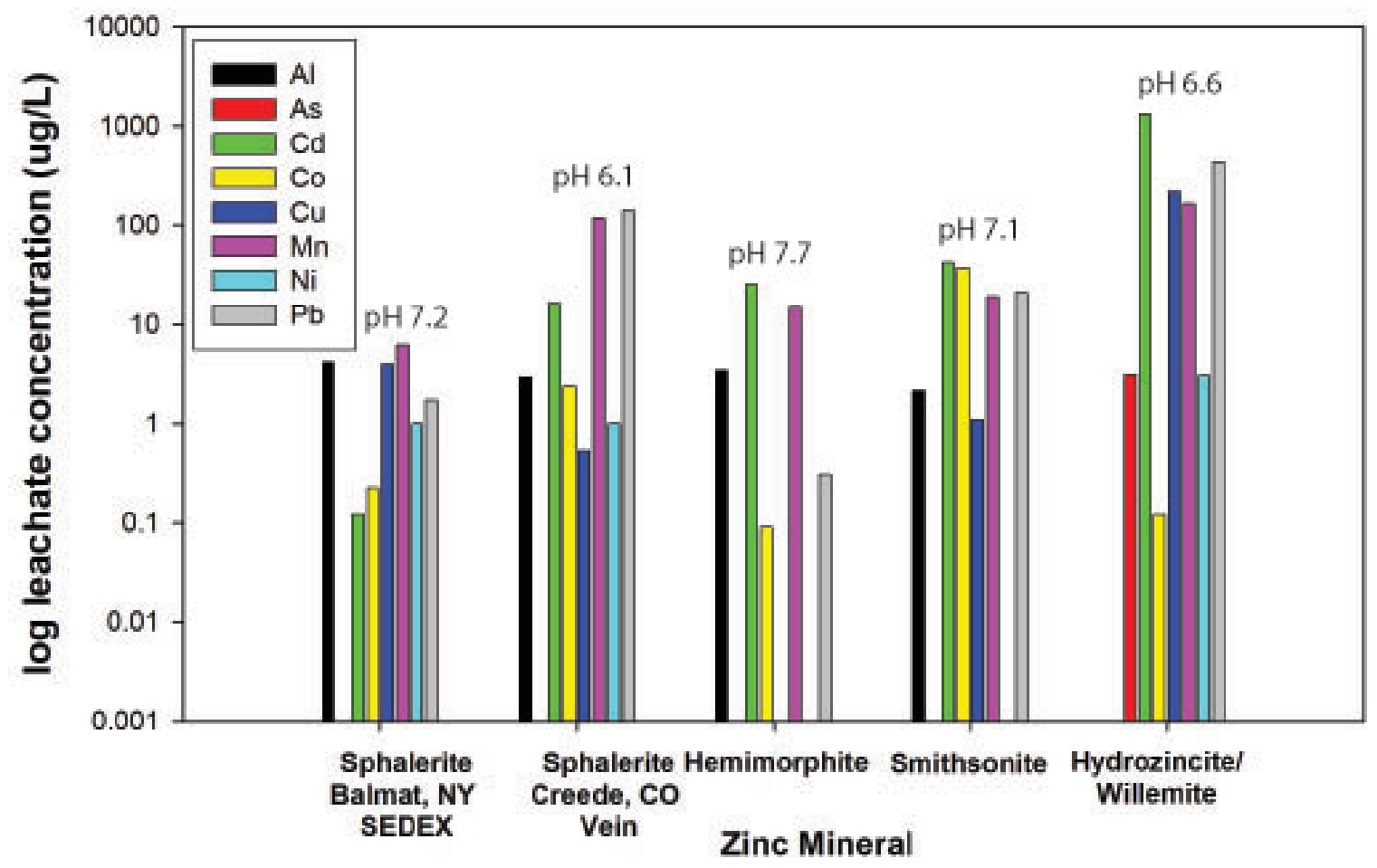

Figure 27. Field leach test (FLT) leachate plot $A$ : Graph plot of selected elements and their concentration in leachates produced using the 5 -minute field leach test (FLT) versus the zinc mineral. SEDEX, sedimentary exhalative deposit; $\mu \mathrm{g} / \mathrm{L}$, micrograms per liter.

Cadmium is present in soluble forms in the sphalerite from the Creede vein deposit as well as in the hydrozincite and smithsonite samples. The importance of cadmium's mode of occurrence is demonstrated by the fact that cadmium is hosted within the lattice structure of the smithsonite mineral as shown in figures $7 C$ and $7 D$ above, whereas cadmium in the hydrozincite sample is hosted in the lattice structure of the accessory calcite. Calcite readily takes up cadmium into its structure and is a more soluble mineral than smithsonite.

\section{Summary of Leaching Studies}

1. The simplified FLT procedure, which uses DI water and a 5-minute agitation, was as effective as the long-term (18-hour agitation) tests in assessing the watersoluble phase of these samples including $\mathrm{pH}$, specific conductance, and watersoluble zinc concentration. Because of its short agitation time, the FLT test may produce results that are more representative of the readily soluble phase of a sample that would be mobilized as runoff under natural conditions.

2. The TCLP leaching procedure produced lower $\mathrm{pH}$ trends, higher conductivity trends, and much higher concentrations of zinc when compared to results produced using the other leach tests. This finding indicates that it is not 
appropriate to use the TCLP procedure to assess the general leachability of geologic materials. Using this procedure to assess general leachability suggests that much more zinc would be mobilized from these minerals than is actually the case. Using the TCLP procedure would only be appropriate if the material were going to be disposed of in a municipal landfill.

3. All leach tests showed major leachate geochemical differences between the Creede sphalerite and the Balmat sphalerite. The Balmat sphalerite had a slightly higher bulk-zinc concentration; whereas the sphalerite from Creede produced leachate with a lower $\mathrm{pH}$, higher conductivity, and moderately higher leachatezinc concentration. These findings show that although samples may have the same mineral name, subtle mineralogic differences such as trace-element content, grain size, and associated minerals make them act quite differently when leached.

4. This study demonstrates the importance of choosing the proper leach test to use for characterization of the soluble fraction of a material. Use of an improper leach test (that is, TCLP) to assess the general leachability of a material will lead to inaccurate findings. Finally, if an investigator wants to mimic the leaching process that occurs in the natural environment, a DI water-based leaching test similar to the FLT should be used.

\section{Acid-Base Accounting Study}

The net acid production (NAP) and the acid neutralizing capacity of the five zinc minerals were determined using the same methods and procedures used in the study of copper minerals (Driscoll and others, 2012). The NAP method used in this study is a modification of a method described by Lapakko and Lawrence (1993). The primary advantage of this method is that it reacts and accounts for both the acid-producing and acid-neutralizing potential of the sample using one test. It should be noted, however, that though this test fully quantifies the acid-producing potential of the sample, it does not quantify the exact neutralizing potential, but instead, only determines that a sample is "net" neutralizing.

The method requires digesting finely ground samples using 30-percent hydrogen peroxide $\left(\mathrm{H}_{2} \mathrm{O}_{2}\right)$. Hydrogen peroxide rapidly oxidizes any sulfides present in the sample thereby forming sulfuric acid $\left(\mathrm{H}_{2} \mathrm{SO}_{4}\right)$, which in turn reacts with acid-neutralizing minerals contained in the sample. After these reactions are complete, the resulting digestate is filtered and titrated (if necessary) to $\mathrm{pH} 7.0$ with $0.1-N$ (normal) sodium hydroxide $(\mathrm{NaOH})$.

To carry out this procedure, $1.0 \mathrm{~g}$ of prepared sample is weighed into a $250-\mathrm{mL}$ Erlenmeyer glass flask. Fifty-mL 30-percent $\mathrm{H}_{2} \mathrm{O}_{2}$ is slowly added to the sample. After all reaction has ceased, another $50-\mathrm{mL}_{2} \mathrm{O}_{2}$ is added, the flask is swirled, and the reaction is allowed to go to completion. A final $50-\mathrm{mL} \mathrm{H}_{2} \mathrm{O}_{2}$ is added, and the flask is swirled, placed on a hotplate and heated at $90{ }^{\circ} \mathrm{C}$. The sample remains on the hotplate until the reaction is completed. The flask is then removed from the hotplate and allowed to cool for 15 minutes. After cooling, 1-mL copper nitrate $\left(\mathrm{CuNO}_{3}\right)$ is added and the contents are again swirled. The flask is returned to the hotplate and brought to boil $\left(\approx 110^{\circ} \mathrm{C}\right)$. After 10 minutes, the flask is removed from the hotplate. When cooled to room temperature, the liquid is filtered into a clean $250-\mathrm{mL}$ glass beaker to remove the solids. As a final step, the solids retained in the filter are rinsed with 1-molar $(M)$ calcium 
chloride $\left(\mathrm{CaCl}_{2}\right)$. Following filtration, the $\mathrm{pH}$ of the filtrate is measured and recorded. If the $\mathrm{pH}$ is greater than 7.0, the sample does not have to be titrated, because this $\mathrm{pH}$ indicates there is net buffering capacity in the sample, and the sample is determined to be net neutral. If the $\mathrm{pH}$ is less than 7.0, the filtrate is titrated with $0.1-N$ sodium hydroxide $(\mathrm{NaOH})$. A stir bar is placed in the beaker, and the solution is constantly stirred during titration. A pH electrode is suspended in the beaker during titration, and solution $\mathrm{pH}$ is constantly monitored. When the solution $\mathrm{pH}$ reaches 7.0 , the quantity of $\mathrm{NaOH}$ consumed during the titration is recorded.

Upon completion of the titration, final NAP is determined by multiplying the number of milliliters $\mathrm{NaOH}$ consumed by the titrant concentration $(0.1)$. The sum is then multiplied by 50 . Data are reported in kilograms calcium carbonate $\left(\mathrm{CaCO}_{3}\right)$ equivalent required to neutralize 1 ton of sample $(\mathrm{kg} / \mathrm{t} \mathrm{CaCO})_{3}$.

\section{Summary of Acid-Base Accounting Study}

This acid-base accounting procedure indicates that only the two sphalerite samples are net-acid producers that require $\mathrm{CaCO}_{3}$ in order to buffer the peroxide digestate (fig. 28.). Once again, the two sphalerite samples acted differently with the Balmat sphalerite requiring more $\mathrm{CaCO}_{3}(555 \mathrm{~kg} / \mathrm{t})$ than the Creede sphalerite $(460 \mathrm{~kg} / \mathrm{t})$ to neutralize the digestate. This indicates that, although both sphalerite samples are net acid producers, the Balmat sphalerite would most likely produce more acid in a natural setting. The hemimorphite, smithsonite, and hydrozincite samples are "net neutralizing" and thus did not require any $\mathrm{CaCO}_{3}$. These three minerals are less likely to produce acid as they weather.

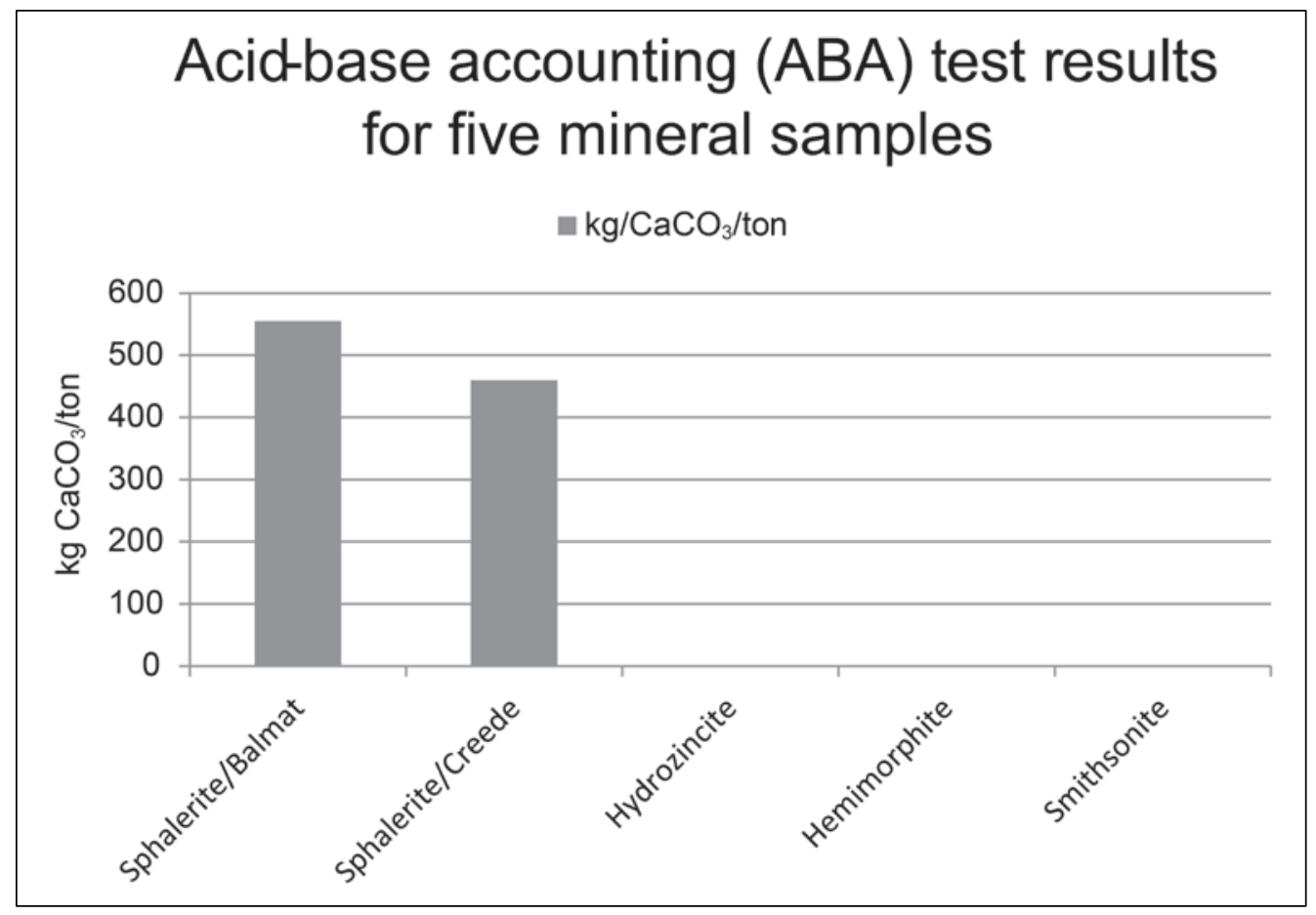

Figure 28. Acid-base accounting (ABA) test results for five zinc-bearing mineral samples. Kg, kilograms. 


\title{
In Vitro Bioaccessibility Extractions
}

\author{
By Suzette Morman
}

Leachate results by extraction fluid: Appendix 4

\section{Introduction}

The term "bioaccessibility," which refers to the fraction of a potential toxicant in soil or other earth materials (that is, volcanic ash, wildfire ash, and dust) that becomes soluble in the stomach and is then available for absorption (Ruby and others, 1993), is often confused with "bioavailability," which is the amount of a potential toxicant absorbed and transported to a site of toxicological action. Generally, studies to examine bioavailability and resulting health effects or toxicity are conducted with animal surrogates or cell-line tests, both of which are time consuming and expensive. In vitro bioaccessibility (IVBA) tests are inexpensive, physiologically based tests designed to estimate the bioaccessibility of elements in soils, dusts, or other environmental materials by measuring the dissolution of the materials of interest in fluids compositionally similar to human body fluids (Morman and others, 2009). Prior sections in this volume discussed methods to identify and quantify major-, minor-, and trace-element abundances of a suite of zinc minerals and presented leachate results that showed the mobility of trace metals and metalloids in simple solutions. The research described below evaluates bioaccessibility via both ingestion and inhalation exposure pathways.

\section{Methods}

The evaluated samples were previously ground (see Driscoll, this volume). For the gastrointestinal extractions, the samples were sieved to $<250 \mu \mathrm{m}$ using a 3-inch stainless steel sieve. The $<250$ - $\mu \mathrm{m}$-size fraction is important as it is reportedly the grain size most likely to adhere to the hands of children and be ingested (Van Wijnen and others, 1990). For the remaining extractions, the samples were sieved to $<20 \mu \mathrm{m}$ using a 3 -inch stainless steel sieve and a Retsch A S200 auto-sieve. Although particles greater than $10 \mu \mathrm{m}$ are generally trapped in the nasopharyngeal region and swallowed, these larger particles may pass into the bronchioles during exercise and mouth breathing. The $<20-\mu \mathrm{m}$-size fraction is a reasonable proxy for respirable-size particles (generally $<5 \mu \mathrm{m}$ ); sieving to the smaller size fraction is difficult and requires additional time and material to obtain sufficient study material. Trace-element abundances in the extraction solutions were analyzed by inductively coupled plasma-mass spectrometry (ICP-MS) (Lamothe and others, 2002). The ICP-MS system was calibrated with multi-element standard solutions prepared from commercially available stock solutions. A procedural blank and duplicate sample were added to each sample batch in support of quality control evaluations. All results were blank-corrected prior to interpretation.

\section{Ingestion Pathway}

In ingestion-pathway evaluations, most IVBA methodologies utilize either a single or sequential extraction with adjustments made to solution composition or $\mathrm{pH}$. For 
this study, we selected a simulated gastric fluid (SGF) extraction protocol (Drexler and Brattin, 2007), identified as a standard operating procedure and approved by the United States Environmental Protection Agency (USEPA, 2008a), to measure bioaccessibility and estimate relative bioavailability of lead. The gastric extraction was followed by an intestinal extraction protocol, described in Basta and others (2007) and developed by Ohio State University researchers (OSU-IVG (in vitro gastrointestinal) method). This procedure is described in detail by Driscoll and others (2012).

\section{Inhalation Pathway}

Both SLF and SPF were utilized to model the inhalation pathway. These simulated body fluids are used to examine a variety of materials (Sun and others, 2001; Herting and others, 2006) and permit modeling of in vitro solubility, an important physiochemical factor that determines the rate and extent that particles are retained at the site of deposition, translocated to other tissues, or excreted (Kanapilly and others, 1973; Kreyling, 1992; Ansoborlo and others, 1999) relative to an inhalation pathway. The lung fluid has neutral $\mathrm{pH}$; the phagolysosomal fluid models the lower $\mathrm{pH}$ (4.5) encountered when particles are engulfed by pulmonary alveolar macrophages, which are specialized lung cells involved in particle removal from the lung.

The composition of the simulated lung fluid and procedures are described by Morman (in Driscoll and others, 2012). A solid to liquid ratio of 1:100 was selected based on previous studies in our laboratory. The procedure specifies that bottles be placed in a preheated $\left(37^{\circ} \mathrm{C}\right)$ incubator to provide both constant rotation and temperature for 24 hours. The composition of the phagolysosomal simulant fluid used is described by Stefaniak and others (2006). The antifungal agent Aldkylbenzyldimethylammonium chloride is not used in our procedure due to concerns that this chemical could introduce contaminants or alter leachate results. The $\mathrm{pH}$ of this leach solution was titrated to 4.5 by the addition of $0.1-\mathrm{M}$ potassium hydroxide solution. The method is identical to that of the simulated lung fluid and uses the same solid to liquid solution ratio $(1: 100)$.

\section{Results}

The primary and secondary zinc minerals in the evaluated sample suite have different morphologies, solubilities (see Hageman, this volume), densities, and host different trace-element concentrations (see Benzel and Diehl, this volume). Therefore, zinc sulfide, zinc carbonate, and zinc silicate should yield different rates of dissolution. Comparison of individual element abundances in leachates, as a function of extraction fluid, allows identification of basic trends, but the number of samples studied is too few to allow robust statistical analysis. Some elements, including $\mathrm{Ag}, \mathrm{Be}, \mathrm{Ni}, \mathrm{Sb}, \mathrm{Se}$, and $\mathrm{V}$, were largely soluble in only the acidic SGF. Other elements, such as $\mathrm{Al}, \mathrm{Ba}, \mathrm{Ca}, \mathrm{Cd}, \mathrm{Co}$, $\mathrm{Fe}, \mathrm{Pb}$, and $\mathrm{Sr}$, demonstrated some solubility in all fluids but showed enhanced bioaccessibility in the acidic SGF and SPF. Only a few elements (As, Cu, Mn, U, and Zn) demonstrated fairly similar and sometimes greater bioaccessibility in the near-neutral simulated lung fluid as well as in the acidic fluids (table 3 and appendix 4). 
Table 3. Total concentration, leachate concentration, and bioaccessibility of selected trace metals.

${ }^{*}$, blank-correction resulted in a negative number; mg, milligrams; $\mathrm{kg}$, kilograms; ppm, parts per million; $\mu \mathrm{g} / \mathrm{L}$, micrograms per liter; nr, not reported due to excess concentration; $<$ RL, value less than the reported limit; SGF, simulated gastric fluid; SIF, simulated intestinal fluid; SLF, simulated lung fluid; SPF, simulated phagolysosomal fluid. Chemistry results were corrected for dilution and blank-corrected prior to calculations]

\begin{tabular}{|c|c|c|c|c|c|c|c|c|}
\hline SGF & As ug/L & $\begin{array}{c}\text { As } \\
\text { (mg leached/ } \\
\text { kg solid) }\end{array}$ & $\begin{array}{c}\text { As } \\
\text { (total, ppm) }\end{array}$ & $\begin{array}{c}\text { As } \\
\% \\
\text { Bioaccessible }\end{array}$ & $\mathrm{Cd} u g / \mathrm{L}$ & $\begin{array}{c}\text { Cd } \\
\text { (mg leached/ } \\
\text { kg solid) }\end{array}$ & $\begin{array}{c}\text { Cd } \\
\text { (total, ppm) }\end{array}$ & $\begin{array}{c}\text { Cd } \\
\% \\
\text { Bioaccessible }\end{array}$ \\
\hline Sphalerite (Balmat, NY) & $<\mathrm{RL}$ & $*$ & 6.7 & $*$ & 16.1 & 1.6 & 1140 & 0.14 \\
\hline Sphalerite (Creede, $\mathrm{CO})$ & 63 & 6.3 & 117 & 5 & 31.8 & 3.2 & 4100 & 0.08 \\
\hline DupSphalerite (Creede,CO) & 65.5 & 6.6 & 117 & 6 & 33.3 & 3.3 & 4100 & 0.08 \\
\hline Hemimorphite & 1820 & 182 & 1620 & 11 & 14200 & 1420 & 1770 & 80 \\
\hline Hydrozincite/Willemite & 601 & 60.1 & 70.4 & 85 & 6170 & 617 & 495 & 125 \\
\hline Smithsonite & 130 & 13 & 41.3 & 31 & 12100 & 1210 & 2950 & 41 \\
\hline \multicolumn{9}{|l|}{ SIF } \\
\hline Sphalerite (Balmat, NY) & 3.3 & 0.3 & 6.7 & 5 & 13.3 & 1.3 & 1140 & 0.11 \\
\hline Sphalerite (Creede,CO) & 94 & 9.4 & 117 & 8 & 5.8 & 0.5 & 4100 & 0.01 \\
\hline DupSphalerite (Creede, CO) & 90 & 9.0 & 117 & 8 & 4.0 & 0.3 & 4100 & 0.01 \\
\hline Hemimorphite & 1820 & 182 & 1620 & 11 & 13400 & 1340 & 1770 & 76 \\
\hline Hydrozincite/Willemite & 267 & 26.7 & 70.4 & 38 & 4640 & 464 & 495 & 94 \\
\hline Smithsonite & 77.3 & 7.7 & 41.3 & 19 & 8670 & 867 & 2950 & 29 \\
\hline \multicolumn{9}{|l|}{ SLF } \\
\hline Sphalerite (Balmat, NY) & $<\mathrm{RL}$ & $<\mathrm{RL}$ & 6.7 & $*$ & $<\mathrm{RL}$ & $<\mathrm{RL}$ & 1140 & $*$ \\
\hline Sphalerite (Creede,CO) & 24.7 & 2.5 & 117 & 2.1 & $<\mathrm{RL}$ & $<\mathrm{RL}$ & 4100 & $*$ \\
\hline Hemimorphite & 1220 & 122 & 1620 & 7.5 & 6.4 & 0.64 & 1770 & 0.04 \\
\hline Hydrozincite/Willemite & 75.2 & 7.5 & 70.4 & 10.7 & 125 & 12.5 & 495 & 2.5 \\
\hline Smithsonite & 21.8 & 2.2 & 41.3 & 5.3 & 27.1 & 2.7 & 2950 & 0.09 \\
\hline DupSmithsonite & 22.2 & 2.2 & 41.3 & 5.4 & 28.2 & 2.8 & 2950 & 0.10 \\
\hline \multicolumn{9}{|l|}{ SPF } \\
\hline Sphalerite (Balmat,NY) & $<\mathrm{RL}$ & $<\mathrm{RL}$ & 6.7 & $*$ & 0.51 & 0.05 & 1140 & 0.004 \\
\hline Sphalerite (Creede, CO) & 86.2 & 8.6 & 117 & 7.4 & 4.4 & 0.44 & 4100 & 0.01 \\
\hline Hemimorphite & 329 & 32.9 & 1620 & 2 & 11700 & 1170 & 1770 & 66 \\
\hline Hydrozincite/Willemite & 28 & 2.8 & 70.4 & 4 & 714 & 71.4 & 495 & 14 \\
\hline Smithsonite & 24.6 & 2.5 & 41.3 & 6 & 2160 & 216 & 2950 & 7.3 \\
\hline DupSmithsonite & 22.4 & 2.2 & 41.3 & 5.4 & 2140 & 214 & 2950 & 7.3 \\
\hline
\end{tabular}


Table 3. Total concentration, leachate concentration, and bioaccessibility of selected trace metals.-Continued

${ }^{*}$, blank-correction resulted in a negative number; mg, milligrams; $\mathrm{kg}$, kilograms; ppm, parts per million; $\mu \mathrm{g} / \mathrm{L}$, micrograms per liter; $\mathrm{nr}$, not reported due to excess concentration; $<\mathrm{RL}$, value less than the reported limit; SGF, simulated gastric fluid; SIF, simulated intestinal fluid; SLF, simulated lung fluid; SPF, simulated phagolysosomal fluid. Chemistry results were corrected for dilution and blank-corrected prior to calculations]

\begin{tabular}{|c|c|c|c|c|c|c|c|c|}
\hline SGF & Cu ug/L & $\begin{array}{c}\mathrm{Cu} \\
\text { (mg leached/ } \\
\mathrm{kg} \text { solid) }\end{array}$ & $\begin{array}{c}\mathrm{Cu} \\
\text { (total, ppm) }\end{array}$ & $\begin{array}{c}\mathrm{Cu} \\
\% \\
\text { Bioaccessible }\end{array}$ & Mn ug/L & $\begin{array}{c}\text { Mn } \\
\text { (mg leached/ } \\
\text { kg solid) }\end{array}$ & $\begin{array}{c}\text { Mn } \\
\text { (total, ppm) }\end{array}$ & $\begin{array}{c}\mathrm{Mn} \\
\% \\
\text { Bioaccessible }\end{array}$ \\
\hline Sphalerite (Balmat, NY) & 5.6 & 0.43 & 47.9 & 1 & 26.4 & 2.6 & 926 & 0.3 \\
\hline Sphalerite (Creede, CO) & 0.86 & $*$ & 792 & $*$ & 293 & 29.3 & 1270 & 2 \\
\hline DupSphalerite (Creede,CO) & $<\mathrm{RL}$ & $*$ & 792 & * & 276 & 27.6 & 1270 & 2 \\
\hline Hemimorphite & 97.7 & 9.6 & 17.6 & 55 & 4830 & 483 & 10400 & 5 \\
\hline Hydrozincite/Willemite & 26200 & 2620 & 2340 & 112 & 2320 & 232 & 1340 & 17 \\
\hline Smithsonite & 1290 & 129 & 165 & 78 & 1670 & 167 & 574 & 29 \\
\hline \multicolumn{9}{|l|}{ SIF } \\
\hline Sphalerite (Balmat, NY) & 14.5 & * & 47.9 & * & 41.4 & 1.3 & 926 & 0.1 \\
\hline Sphalerite (Creede,CO) & 17.6 & * & 792 & * & 232 & 20.4 & 1270 & 2 \\
\hline DupSphalerite (Creede, CO) & 15 & * & 792 & $*$ & 237 & 20.9 & 1270 & 2 \\
\hline Hemimorphite & 117 & 9.4 & 17.6 & 54 & 3890 & 386 & 10400 & 4 \\
\hline Hydrozincite/Willemite & 17100 & 1708 & 2340 & 73 & 1280 & 125 & 1340 & 9 \\
\hline Smithsonite & 920 & 90 & 165 & 54 & 963 & 94 & 574 & 16 \\
\hline \multicolumn{9}{|l|}{ SLF } \\
\hline Sphalerite (Balmat, NY) & $<\mathrm{RL}$ & $<\mathrm{RL}$ & 47.9 & $*$ & 39.9 & 4.0 & 926 & 0.43 \\
\hline Sphalerite (Creede,CO) & 6.1 & 0.61 & 792 & 0.08 & 165 & 16.5 & 1270 & 1.3 \\
\hline Hemimorphite & 112 & 11.2 & 17.6 & 64 & 131 & 13.1 & 10400 & 0.13 \\
\hline Hydrozincite/Willemite & 5060 & 506 & 2340 & 22 & 36.5 & 3.7 & 1340 & 0.27 \\
\hline Smithsonite & 222 & 22.2 & 165 & 13 & 40.8 & 4.08 & 574 & 0.71 \\
\hline DupSmithsonite & 229 & 22.9 & 165 & 14 & 44.1 & 4.41 & 574 & 0.77 \\
\hline \multicolumn{9}{|l|}{ SPF } \\
\hline Sphalerite (Balmat,NY) & $<\mathrm{RL}$ & $<\mathrm{RL}$ & 47.9 & $*$ & 88.2 & 8.8 & 926 & 1.0 \\
\hline Sphalerite (Creede, CO) & $<\mathrm{RL}$ & $<\mathrm{RL}$ & 792 & $*$ & 448 & 44.8 & 1270 & 3.5 \\
\hline Hemimorphite & 79.6 & 8 & 17.6 & 45 & 2390 & 239 & 10400 & 2.3 \\
\hline Hydrozincite/Willemite & 8240 & 824 & 2340 & 35 & 572 & 57.2 & 1340 & 4.3 \\
\hline Smithsonite & 464 & 46 & 165 & 28 & 431 & 43.1 & 574 & 7.5 \\
\hline DupSmithsonite & 467 & 47 & 165 & 28 & 441 & 44.1 & 574 & 7.7 \\
\hline
\end{tabular}


Table 3. Total concentration, leachate concentration, and bioaccessibility of selected trace metals.-Continued

${ }^{*}$, blank-correction resulted in a negative number; mg, milligrams; $\mathrm{kg}$, kilograms; ppm, parts per million; $\mu \mathrm{g} / \mathrm{L}$, micrograms per liter; $\mathrm{nr}$, not reported due to excess concentration; $<$ RL, value less than the reported limit; SGF, simulated gastric fluid; SIF, simulated intestinal fluid; SLF, simulated lung fluid; SPF, simulated phagolysosomal fluid. Chemistry results were corrected for dilution and blank-corrected prior to calculations]

\begin{tabular}{|c|c|c|c|c|c|c|c|c|}
\hline SGF & $\mathrm{Pb} u g / \mathrm{L}$ & $\begin{array}{c}\mathrm{Pb} \\
\text { (mg leached/ } \\
\mathrm{kg} \text { solid) }\end{array}$ & $\begin{array}{c}\mathrm{Pb} \\
\text { (total, ppm) }\end{array}$ & $\begin{array}{c}\mathrm{Pb} \\
\% \\
\text { Bioaccessible }\end{array}$ & U ug/L & $\begin{array}{c}\mathrm{U} \\
\text { (mg leached/ } \\
\mathrm{kg} \text { solid) }\end{array}$ & $\begin{array}{c}\text { U } \\
\text { (total, ppm) }\end{array}$ & $\begin{array}{c}\mathrm{U} \\
\% \\
\text { Bioaccessible }\end{array}$ \\
\hline Sphalerite (Balmat, NY) & 25.4 & 2 & 60.8 & 4 & 5.5 & 0.55 & 4.9 & 11 \\
\hline Sphalerite (Creede, CO) & 2030 & 203 & 14400 & 1 & 0.51 & 0.05 & 0.64 & 8 \\
\hline DupSphalerite (Creede,CO) & 1530 & 153 & 14400 & 1 & 0.5 & 0.05 & 0.64 & 8 \\
\hline Hemimorphite & 247 & 25 & 1320 & 2 & 7.3 & 0.73 & 30.5 & 2 \\
\hline Hydrozincite/Willemite & 37500 & 3750 & 4950 & 76 & 6120 & 612 & 514 & 119 \\
\hline Smithsonite & 15300 & 1530 & 1180 & 130 & 11.5 & 1.15 & 0.41 & 280 \\
\hline \multicolumn{9}{|l|}{ SIF } \\
\hline Sphalerite (Balmat, NY) & 5.9 & * & 60.8 & * & 0.83 & 0.08 & 4.9 & 2 \\
\hline Sphalerite (Creede,CO) & 450 & 44 & 14400 & 0.3 & 0.24 & 0.02 & 0.64 & 4 \\
\hline DupSphalerite (Creede, CO) & 469 & 46 & 14400 & 0.3 & 0.19 & 0.02 & 0.64 & 3 \\
\hline Hemimorphite & 11.6 & 0.1 & 1320 & 0.01 & 1.5 & 0.15 & 30.5 & 0.5 \\
\hline Hydrozincite/Willemite & 10400 & 1039 & 4950 & 21 & 132 & 13 & 514 & 3 \\
\hline Smithsonite & 2030 & 202 & 1180 & 17 & 1.15 & 0.12 & 0.41 & 28 \\
\hline \multicolumn{9}{|l|}{ SLF } \\
\hline Sphalerite (Balmat, NY) & 1.2 & $*$ & 60.8 & $*$ & 11.2 & 1.1 & 4.9 & 23 \\
\hline Sphalerite (Creede,CO) & 214 & 21.2 & 14400 & 0.15 & $<\mathrm{RL}$ & $<\mathrm{RL}$ & 0.64 & $*$ \\
\hline Hemimorphite & $<\mathrm{RL}$ & $<\mathrm{RL}$ & 1320 & $*$ & 7.0 & 0.7 & 30.5 & 2 \\
\hline Hydrozincite/Willemite & 109 & 10.7 & 4950 & 0.22 & 733 & 73 & 514 & 14 \\
\hline Smithsonite & 21.7 & 2.0 & 1180 & 0.17 & 4.3 & 0.4 & 0.41 & 105 \\
\hline DupSmithsonite & 23.2 & 2.1 & 1180 & 0.18 & 4.5 & 0.4 & 0.41 & 109 \\
\hline \multicolumn{9}{|l|}{ SPF } \\
\hline Sphalerite (Balmat,NY) & 13.9 & 1.2 & 60.8 & 2.0 & 12.8 & 1.3 & 4.9 & 26 \\
\hline Sphalerite (Creede, CO) & 6520 & 652 & 14400 & 4.5 & $<1$ & $<\mathrm{RL}$ & 0.64 & $*$ \\
\hline Hemimorphite & 7.2 & 0.56 & 1320 & 0.04 & 2.2 & 0.22 & 30.5 & 0.73 \\
\hline Hydrozincite/Willemite & 10100 & 1010 & 4950 & 20 & 2050 & 205 & 514 & 40 \\
\hline Smithsonite & 6460 & 646 & 1180 & 55 & 3.6 & 0.36 & 0.41 & 87 \\
\hline DupSmithsonite & 6490 & 649 & 1180 & 55 & 3.2 & 0.32 & 0.41 & 79 \\
\hline
\end{tabular}


Table 3. Total concentration, leachate concentration, and bioaccessibility of selected trace metals.-Continued

${ }^{*}$, blank-correction resulted in a negative number; mg, milligrams; $\mathrm{kg}$, kilograms; ppm, parts per million; $\mu \mathrm{g} / \mathrm{L}$, micrograms per liter; $\mathrm{nr}$, not reported due to excess concentration; $<\mathrm{RL}$, value less than the reported limit; SGF, simulated gastric fluid; SIF, simulated intestinal fluid; SLF, simulated lung fluid; SPF, simulated phagolysosomal fluid. Chemistry results were corrected for dilution and blank-corrected prior to calculations]

\begin{tabular}{|c|c|c|c|c|}
\hline SGF & Zn ug/L & $\begin{array}{c}\mathrm{Zn} \\
\text { (mg leached/ } \\
\mathrm{kg} \text { solid) }\end{array}$ & $\begin{array}{c}\mathrm{Zn} \\
\text { (total, ppm) }\end{array}$ & $\begin{array}{c}\mathrm{Zn} \\
\% \\
\text { Bioaccessible }\end{array}$ \\
\hline Sphalerite (Balmat, NY) & 6550 & 651 & 635000 & 0.1 \\
\hline Sphalerite (Creede, CO) & 13800 & 1376 & 587000 & 0.2 \\
\hline DupSphalerite (Creede,CO) & 14600 & 1456 & 587000 & 0.2 \\
\hline Hemimorphite & 2790000 & 278996 & 382000 & 73 \\
\hline Hydrozincite/Willemite & 5160000 & 515996 & 561000 & 92 \\
\hline Smithsonite & 1750000 & 174996 & 504000 & 35 \\
\hline \multicolumn{5}{|l|}{ SIF } \\
\hline Sphalerite (Balmat, NY) & 5530 & 482 & 635000 & 0.08 \\
\hline Sphalerite (Creede,CO) & 10600 & 989 & 587000 & 0.2 \\
\hline DupSphalerite (Creede, CO) & 9920 & 921 & 587000 & 0.2 \\
\hline Hemimorphite & 2440000 & 243929 & 382000 & 64 \\
\hline Hydrozincite/Willemite & 4600000 & 459929 & 561000 & 82 \\
\hline Smithsonite & 1580000 & 157929 & 504000 & 31 \\
\hline \multicolumn{5}{|l|}{ SLF } \\
\hline Sphalerite (Balmat, NY) & 3540 & 350 & 635000 & 0.06 \\
\hline Sphalerite (Creede,CO) & 3940 & 390 & 587000 & 0.07 \\
\hline Hemimorphite & 4230 & 419 & 382000 & 0.11 \\
\hline Hydrozincite/Willemite & 4450 & 441 & 561000 & 0.08 \\
\hline Smithsonite & 6520 & 648 & 504000 & 0.13 \\
\hline DupSmithsonite & 6490 & 645 & 504000 & 0.13 \\
\hline \multicolumn{5}{|l|}{ SPF } \\
\hline Sphalerite (Balmat,NY) & 15400 & 1535.9 & 635000 & 0.24 \\
\hline Sphalerite (Creede, CO) & 19200 & 1915.9 & 587000 & 0.33 \\
\hline Hemimorphite & 223000 & 22295.9 & 382000 & 5.8 \\
\hline Hydrozincite/Willemite & 428000 & 42795.9 & 561000 & 7.6 \\
\hline Smithsonite & 390000 & 38995.9 & 504000 & 7.7 \\
\hline DupSmithsonite & 392000 & 39195.9 & 504000 & 7.8 \\
\hline
\end{tabular}


Bioaccessibility is calculated as

(mg leached by extraction fluid per $\mathrm{kg}$ soil)/(total concentration in soil (in $\mathrm{mg} / \mathrm{kg})) \times 100$.

For some elements, in some samples, blank-correcting leachate abundances resulted in negative numbers and bioaccessibility could not be quantified. Concentrations of trace elements in some leachate samples were less than the reporting level (RL); these data are not reported in table 1 or appendix 4. Bioaccessibility values in excess of 100 percent may result from analytical error stemming from incomplete solid digestion, sample heterogeneity, or solid:solution ratio.

The five samples contain total zinc concentrations that range from 382,000 mg/kg (hemimorphite) to $635,000 \mathrm{mg} / \mathrm{kg}$ (Balmat sphalerite). Zinc bioaccessibility was low for both the Balmat and Creede sphalerite samples in all leachate solutions ( $<1$ percent). Zinc bioaccessibility for the other three alteration minerals was significantly higher, particularly for the two carbonates - hydrozincite and smithsonite. The carbonate minerals exhibit greater bioaccessibility for several elements (arsenic, cadmium, and lead) despite having wholesample concentrations that are similar to those of the two sphalerite samples. The hemimorphite sample, classified as a silicate, yielded both high total concentrations and bioaccessibility of several trace metal(loid)s with known human and ecosystem health risks (table 3).

Low zinc solubility is observed $(<1$ percent) for all mineral samples in the neutral $\mathrm{pH}$ SLF (figs. 29-32). Given the total concentrations, however, this still amounts to elevated concentrations in solution (table 3). Figures 29-32 show the bioaccessibility of zinc by mineral and leachate type.

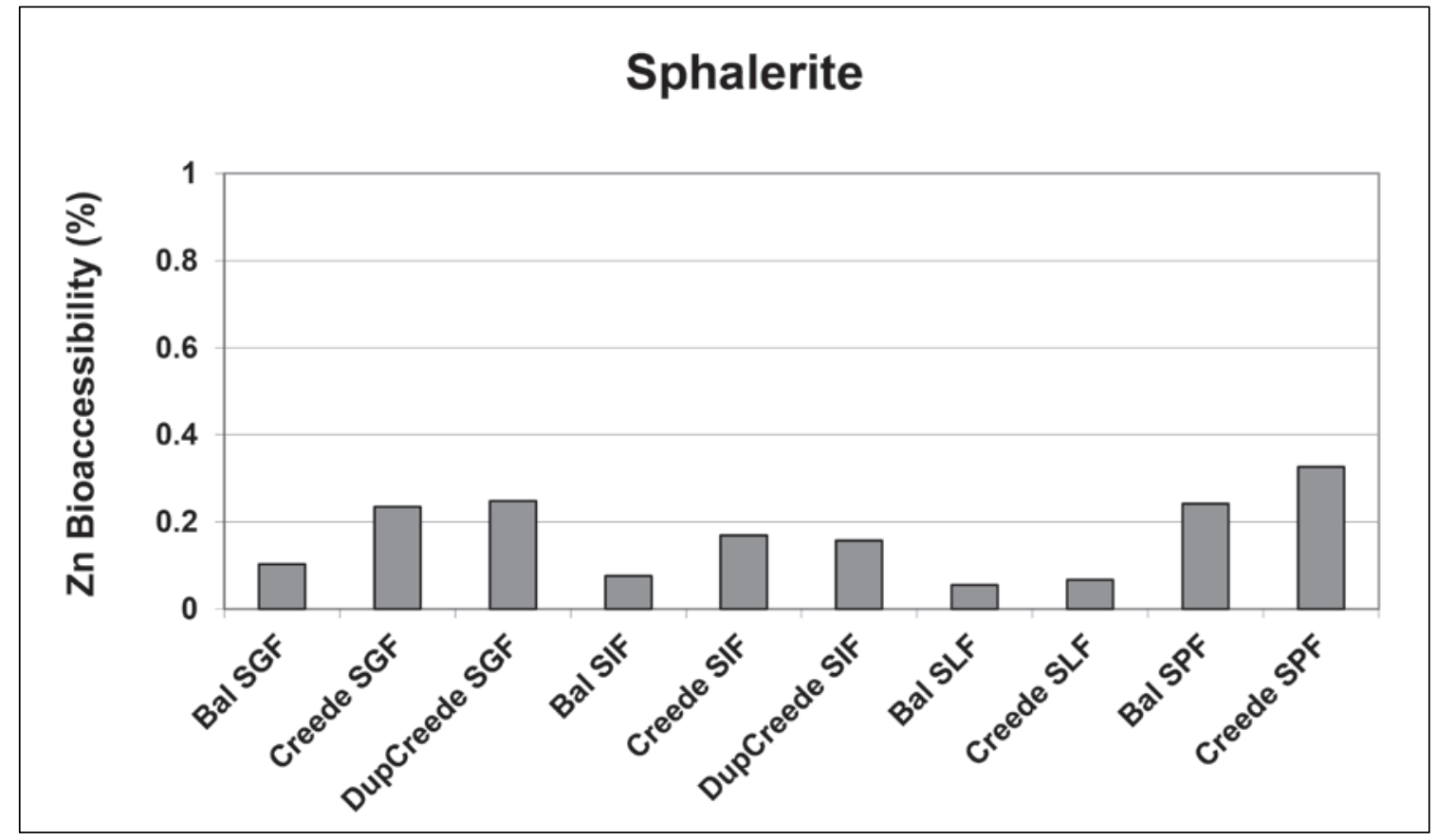

Figure 29. Bioaccessibility of zinc (Zn) for Balmat, New York, and Creede, Colorado, sphalerite samples measured in simulated gastric fluid (SGF), simulated intestinal fluid (SIF), simulated lung fluid (SLF), and simulated phagolysosomal fluid (SPF) presented as the percent of the solid soluble in the fluid. 


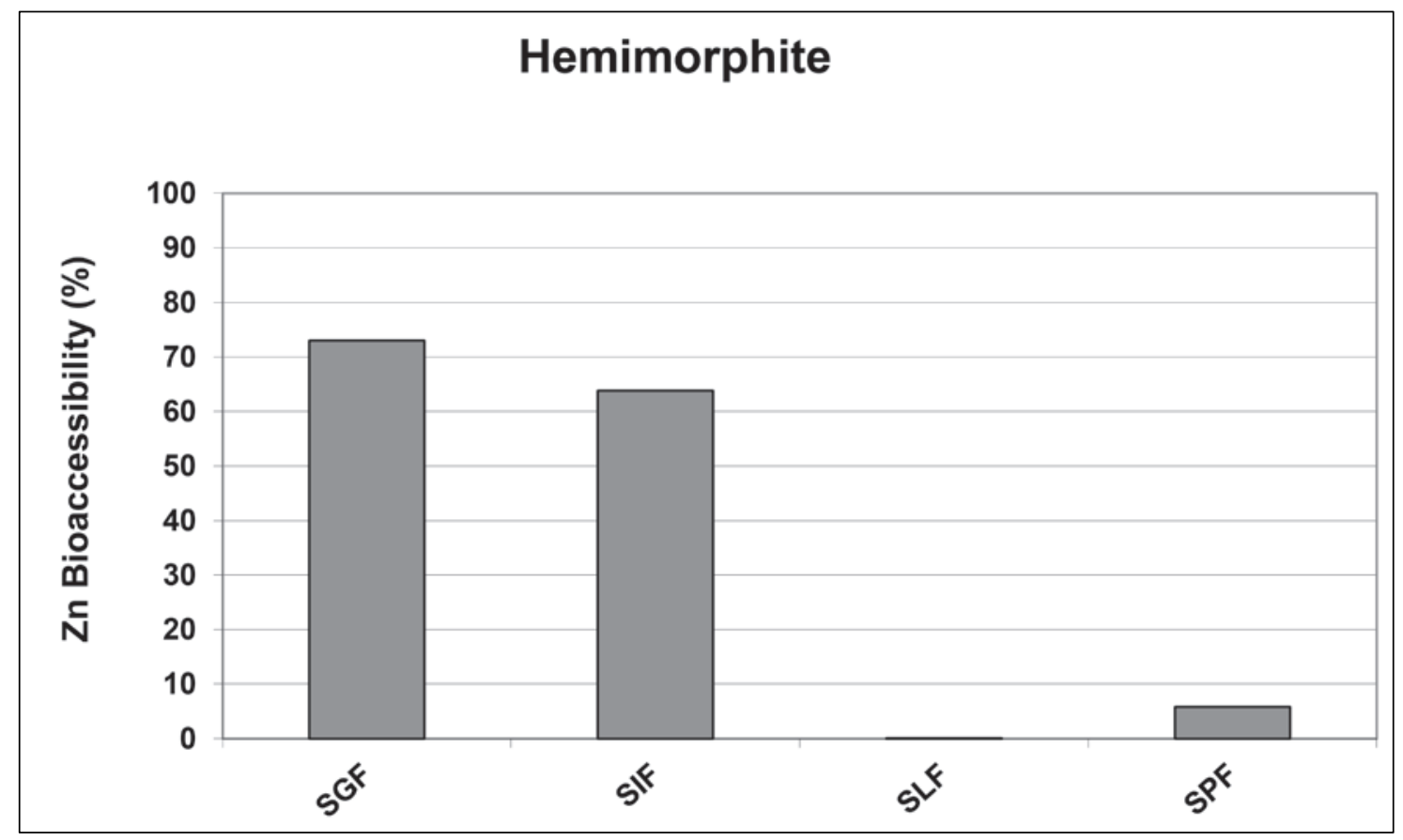

Figure 30. Bioaccessibility of zinc $(\mathrm{Zn})$ for hemimorphite sample measured in simulated gastric fluid (SGF), simulated intestinal fluid (SIF), simulated lung fluid (SLF), and simulated phagolysosomal fluid (SPF) presented as the percent of the solid soluble in the fluid.

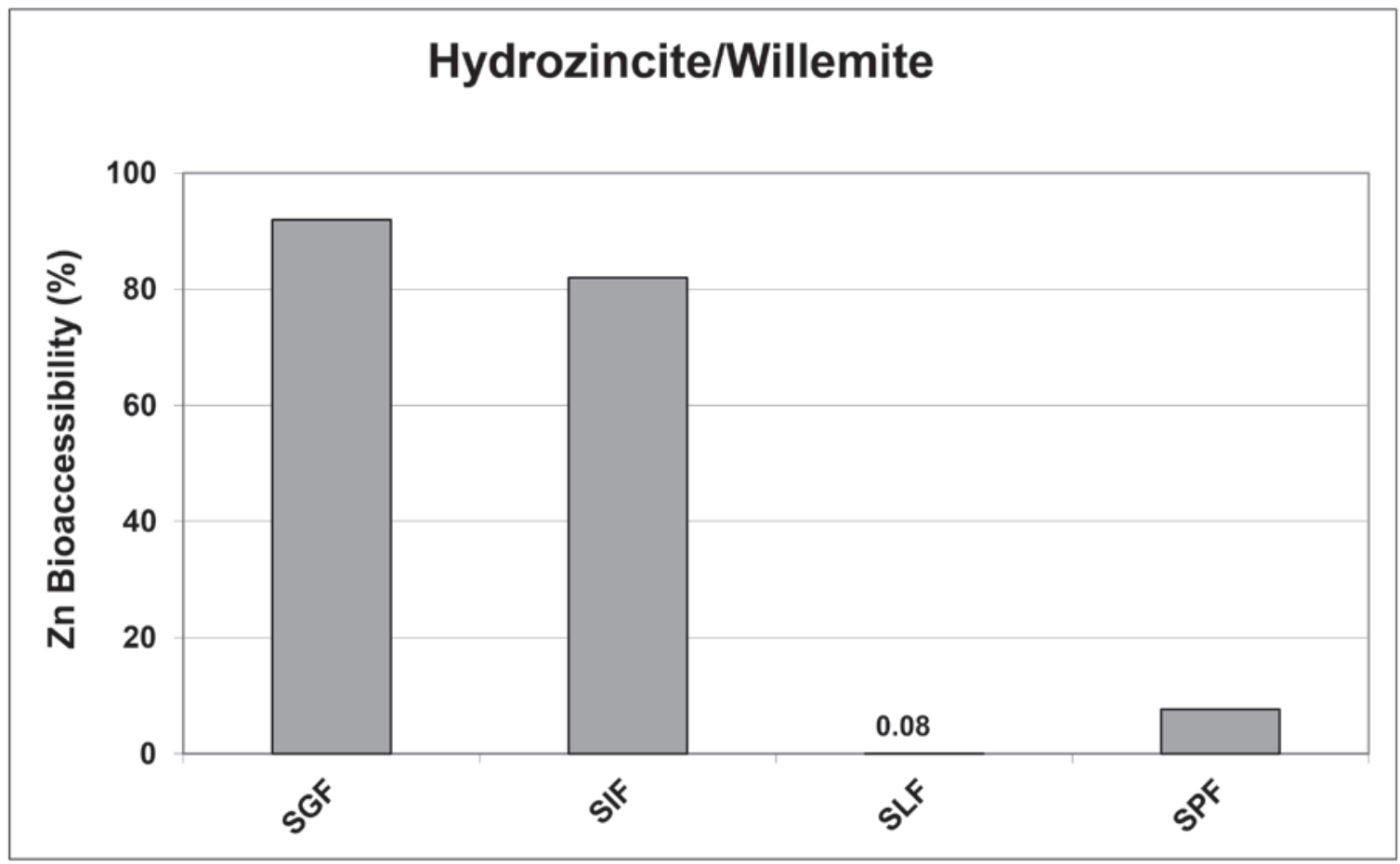

Figure 31. Bioaccessibility of zinc (Zn) for hydrozincite/willemite sample measured in simulated gastric fluid (SGF), simulated intestinal fluid (SIF), simulated lung fluid (SLF), and simulated phagolysosomal fluid (SPF) presented as the percent of the solid soluble in the fluid. 


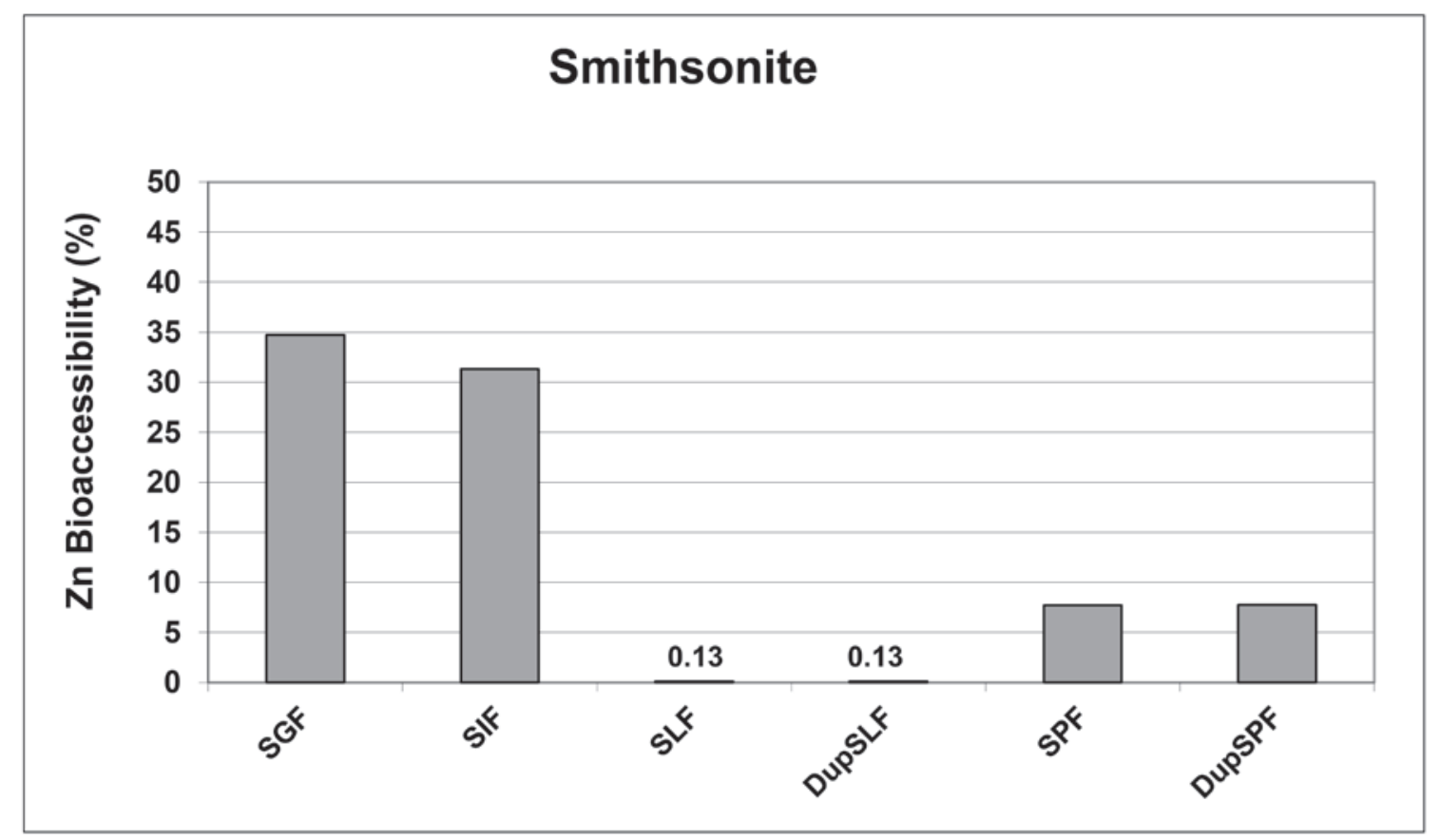

Figure 32. Bioaccessibility of zinc $(\mathrm{Zn})$ for smithsonite sample measured in simulated gastric fluid (SGF), simulated intestinal fluid (SIF), simulated lung fluid (SLF), and simulated phagolysosomal fluid (SPF) presented as the percent of the solid soluble in the fluid. Dup, duplicate.

Figures 33-36 demonstrate the variability of arsenic bioaccessibility by mineral and extraction fluid.

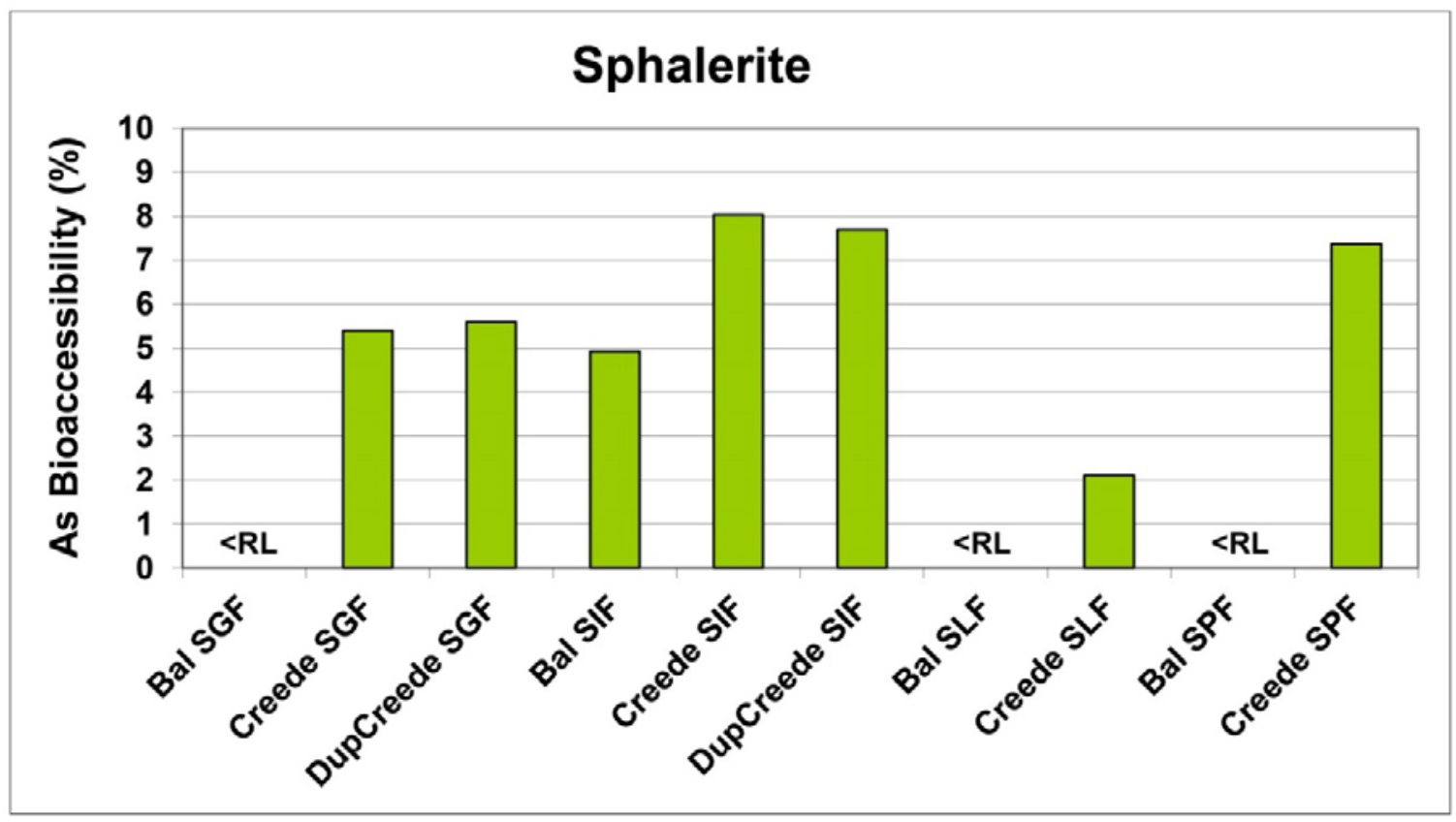

Figure 33. Bioaccessibility of arsenic (As) for Balmat (Bal) and Creede sphalerite samples measured in simulated gastric fluid (SGF), simulated intestinal fluid (SIF), simulated lung fluid (SLF), and simulated phagolysosomal fluid (SPF) presented as the percent of the solid soluble in the fluid. RL, reporting level. 


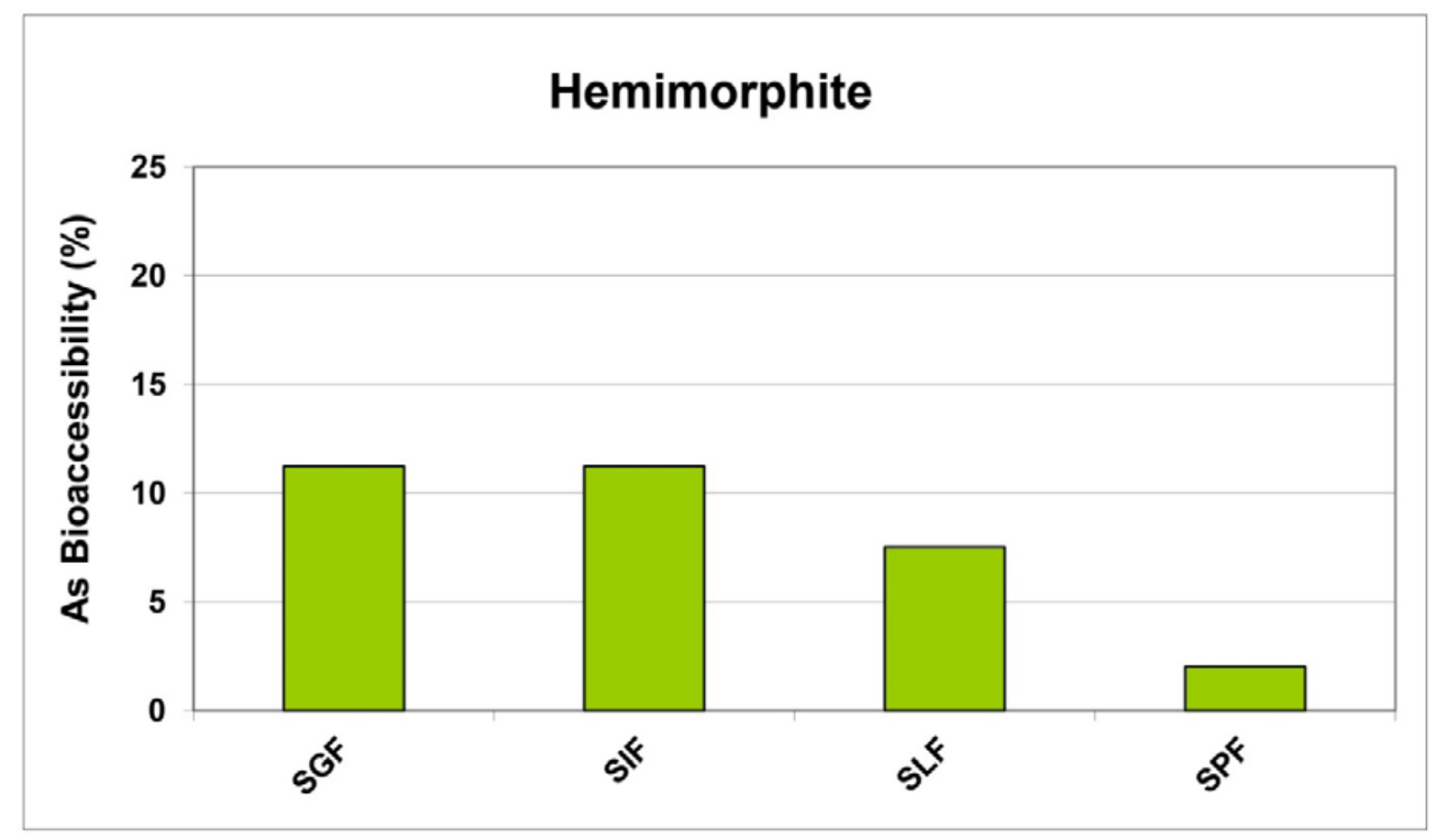

Figure 34. Bioaccessibility of arsenic (As) for hemimorphite sample measured in simulated gastric fluid (SGF), simulated intestinal fluid (SIF), simulated lung fluid (SLF), and simulated phagolysosomal fluid (SPF) presented as the percent of the solid soluble in the fluid.

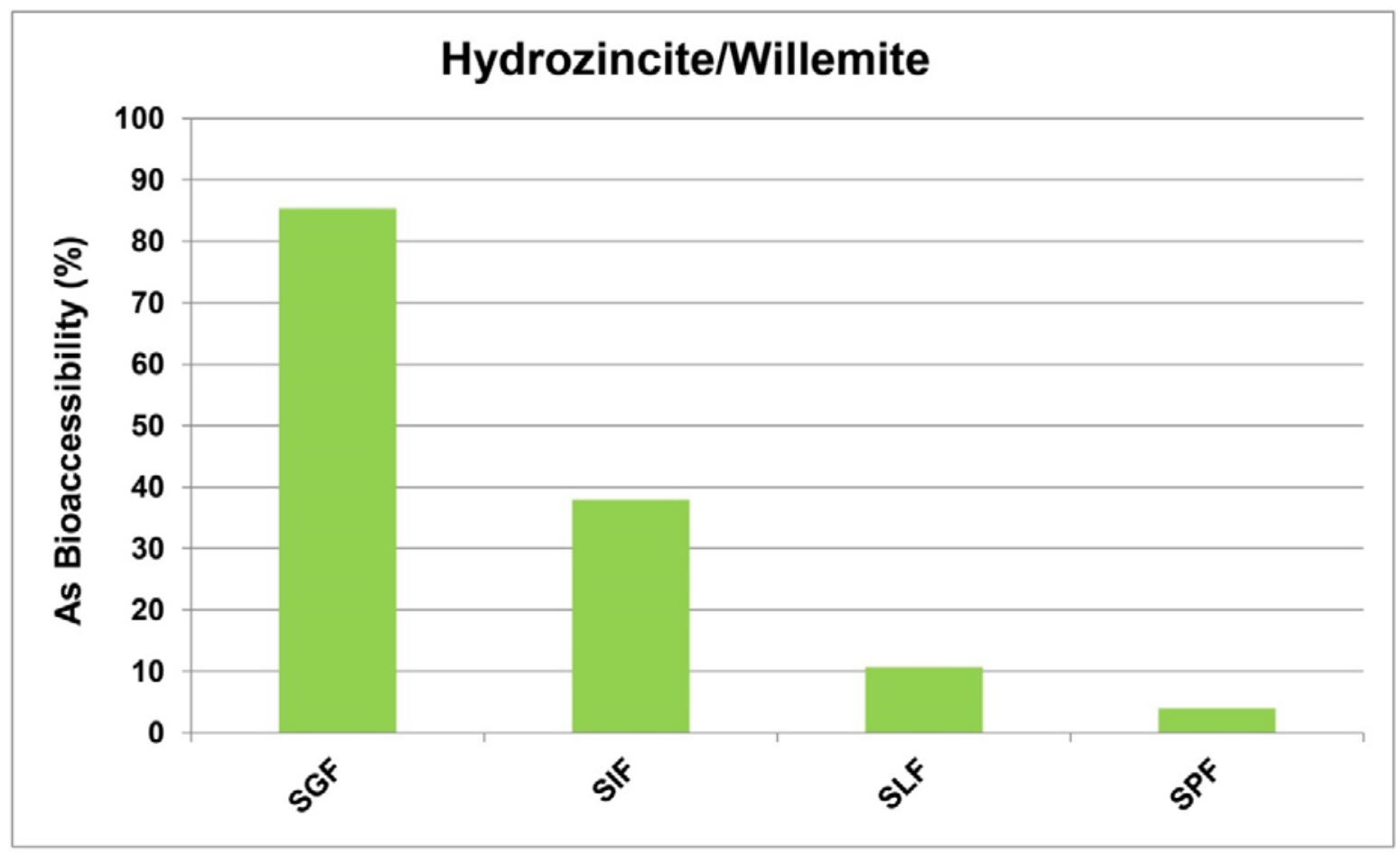

Figure 35. Bioaccessibility of arsenic (As) for hydrozincite/willemite sample measured in simulated gastric fluid (SGF), simulated intestinal fluid (SIF), simulated lung fluid (SLF), and simulated phagolysosomal fluid (SPF) presented as the percent of the solid soluble in the fluid. 


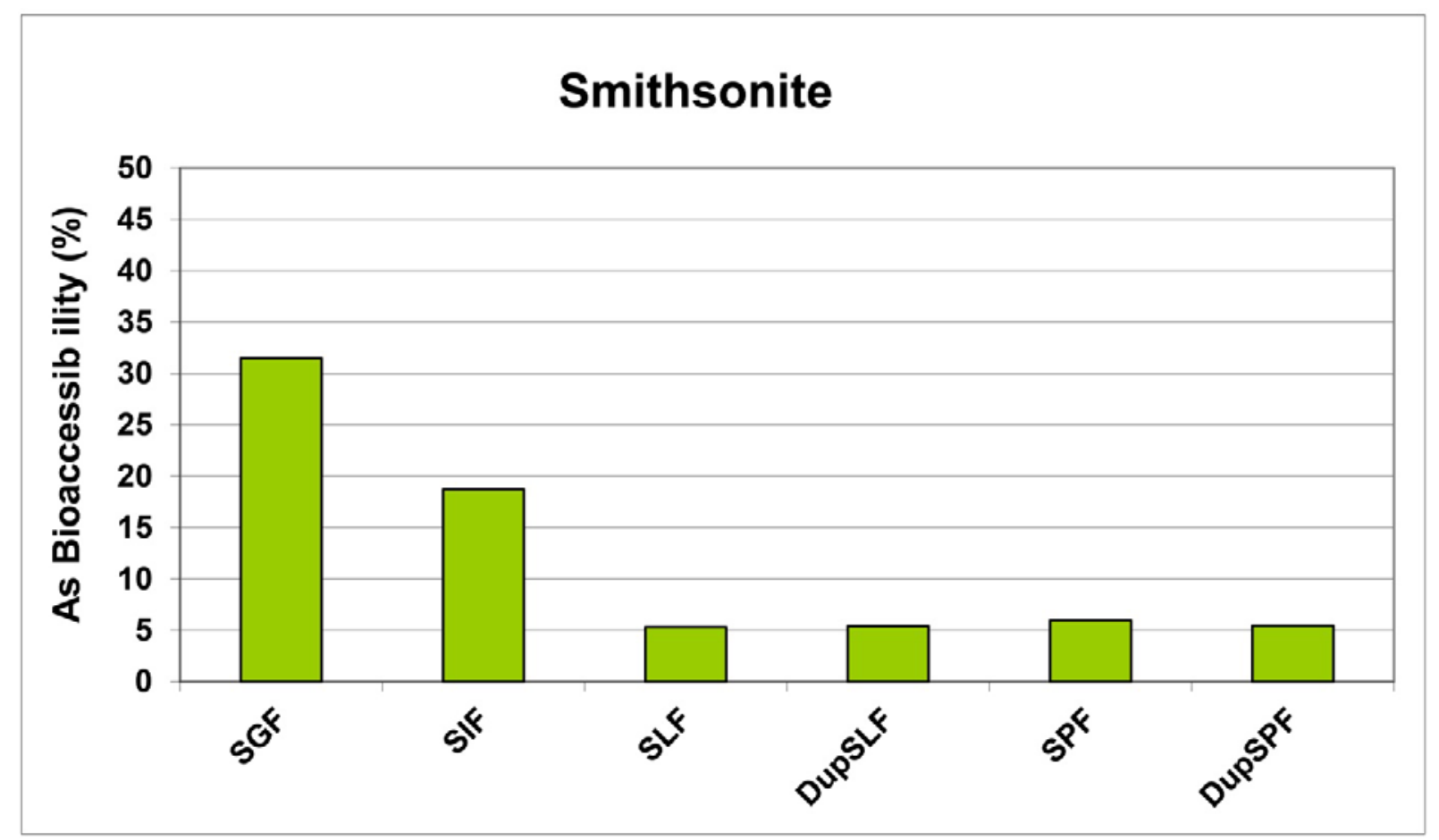

Figure 36. Bioaccessibility of arsenic (As) for smithsonite sample measured in simulated gastric fluid (SGF), simulated intestinal fluid (SIF), simulated lung fluid (SLF), and simulated phagolysosomal fluid (SPF) presented as the percent of the solid soluble in the fluid. Dup, duplicate.

Hemimorphite, with the highest total arsenic concentration, displays bioaccessibility values closer to that of the zinc sulfides than the zinc carbonates. However, hemimorphite exhibits greater cadmium bioaccessibility than smithsonite and its cadmium bioaccessibility is equal to that of the hydrozincite (figs. 37-40). 


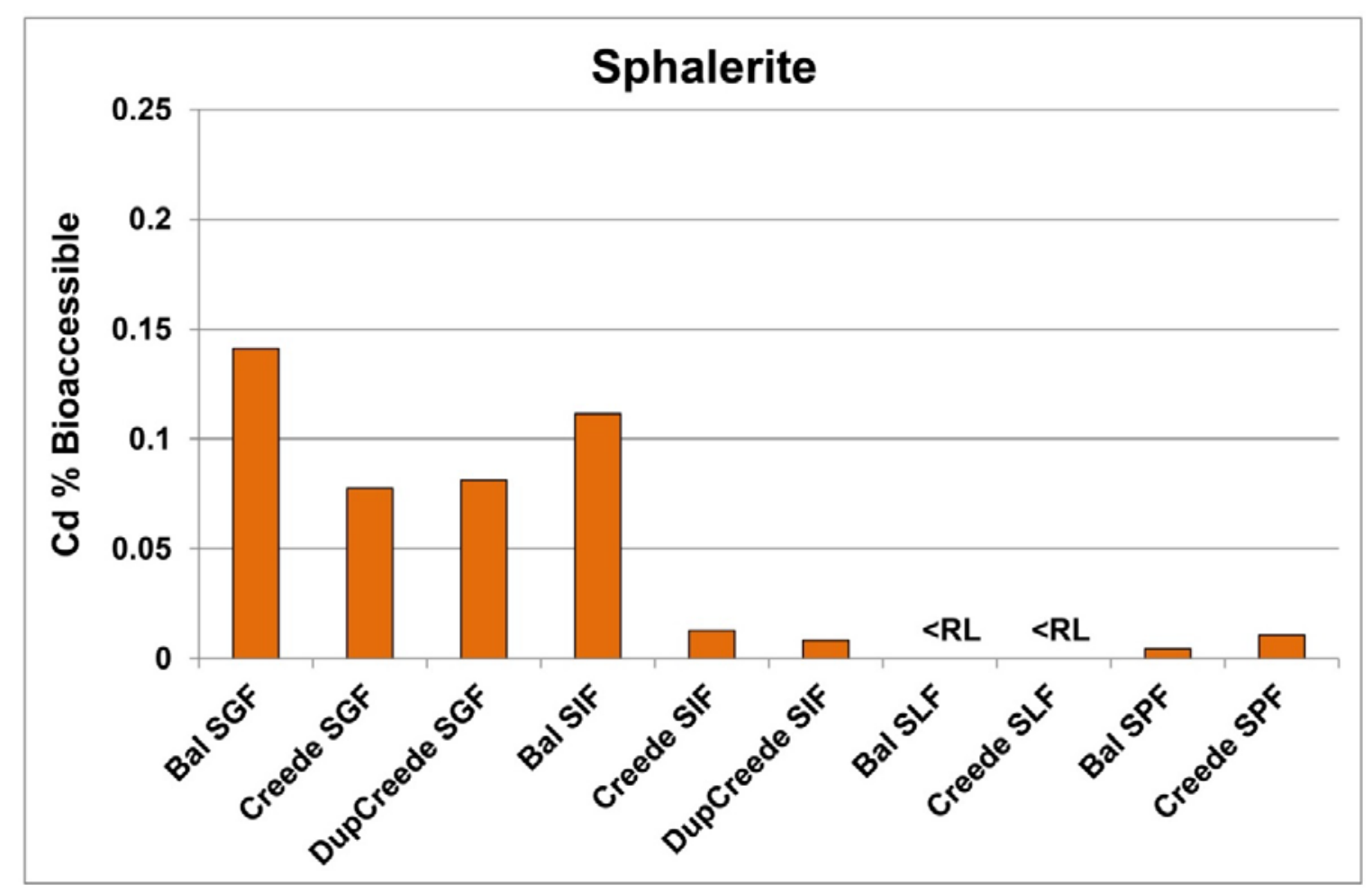

Figure 37. Bioaccessibility of cadmium (Cd) for Balmat (Bal) and Creede sphalerite samples measured in simulated gastric fluid (SGF), simulated intestinal fluid (SIF), simulated lung fluid (SLF), and simulated phagolysosomal fluid (SPF) presented as the percent of the solid soluble in the fluid. RL, reporting level; Dup, duplicate.

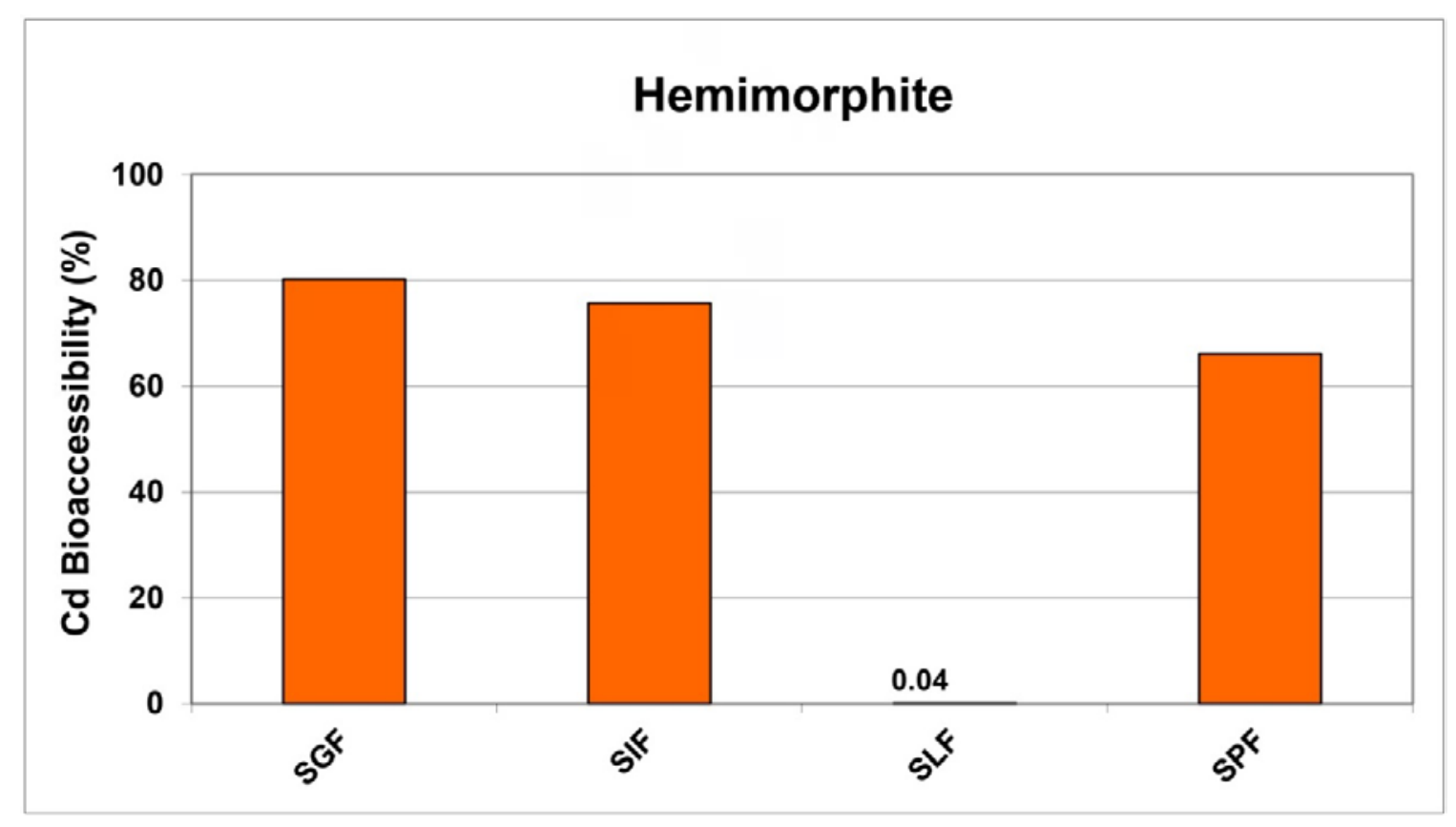

Figure 38. Bioaccessibility of cadmium (Cd) for hemimorphite sample measured in simulated gastric fluid (SGF), simulated intestinal fluid (SIF), simulated lung fluid (SLF), and simulated phagolysosomal fluid (SPF) presented as the percent of the solid soluble in the fluid. 


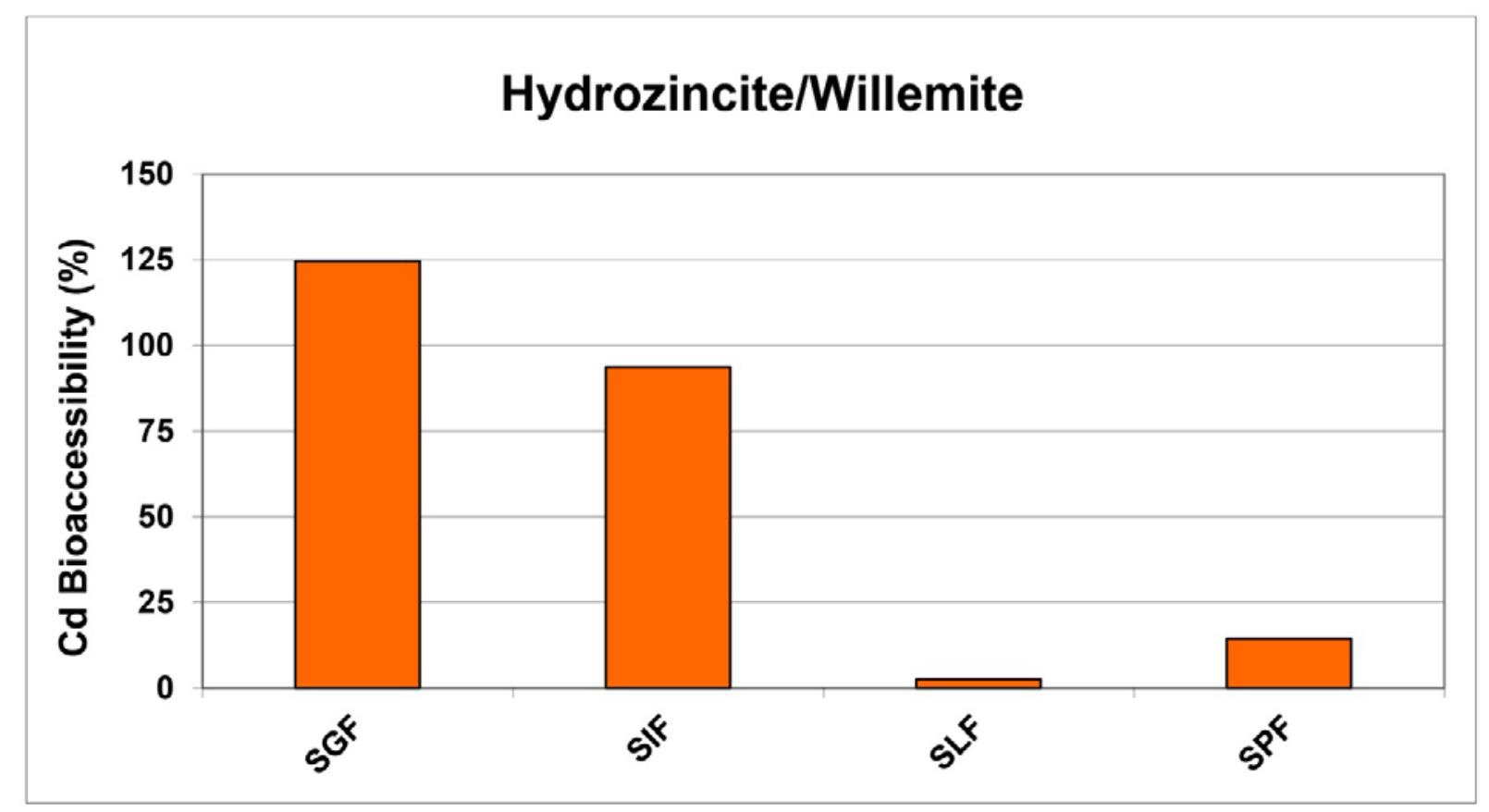

Figure 39. Bioaccessibility of cadmium (Cd) for hydrozincite/willemite sample measured in simulated gastric fluid (SGF), simulated intestinal fluid (SIF), simulated lung fluid (SLF), and simulated phagolysosomal fluid (SPF) presented as the percent of the solid soluble in the fluid.

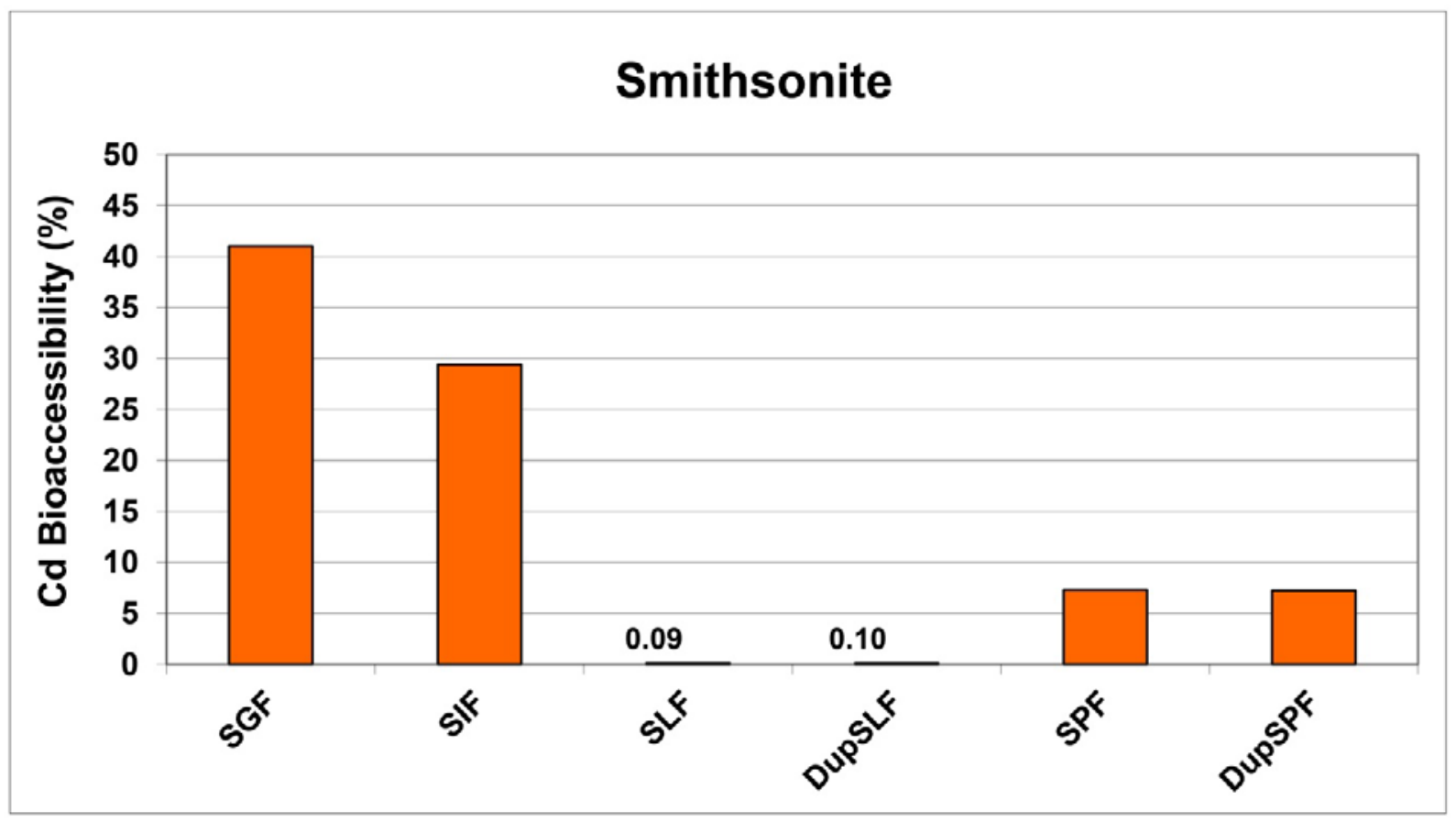

Figure 40. Bioaccessibility of cadmium (Cd) for smithsonite sample measured in simulated gastric fluid (SGF), simulated intestinal fluid (SIF), simulated lung fluid (SLF), and simulated phagolysosomal fluid (SPF) presented as the percent of the solid soluble in the fluid. Dup, duplicate. 


\section{Discussion}

Five zinc-bearing mineral samples were chosen for this study. Zinc, an essential element, has a daily intake requirement since there is no specific storage system for zinc in the body (National Institutes of Health, 2011). This requirement is usually easily achieved through meat and milk consumption, but a zinc deficiency may be a feature of certain cultures and can be associated with poverty. Zinc influences many physiological functions in the body including immunity, brain development and function, growth, and nerve conduction. Zinc is also a catalytic metal ion in many enzymes and proteins in the body. Toxic exposures are generally related to occupational exposures such as zinc oxide fumes (Gordon and Fine, 1993), although poisoning from ingestion of zinc-contaminated food and drink, which can result in gastrointestinal distress, has been reported (Standstead and $\mathrm{Au}, 2007$ ).

Although this study evaluates monomineralic samples of zinc minerals, ore-deposit studies indicate that the abundances of diverse elements vary in the environment as a consequence of associated ore-deposit type and geologic setting. Mine-waste chemistry and mineralogy is complex because most ore minerals host many trace elements that are not a part of stoichiometric formulae. These trace-element impurities affect the physical and chemical behavior of the minerals as they weather in place or in waste piles and tailings ponds. No similar studies examining zinc bioaccessibility from primarily monomineralic samples to determine zinc bioaccessibility in the simulated body fluids utilized here were discovered for comparison.

Many studies have examined bioaccessibility of minerals in mine waste (Ruby and others, 1996) or soils affected by ore extraction and processing (Brumbaugh and Morman, 2011) or smelter-related deposition (Ettler and others, 2012). Additional studies have examined how particle size, soil $\mathrm{pH}$, the organic carbon content, and the presence of clays and iron or manganese oxides affect element mobility and controls on bioaccessibility. This study focused on mineral solubility in fluids with a composition and $\mathrm{pH}$ similar to that of human body fluids. Results presented here indicate that mineral morphology and solution $\mathrm{pH}$ strongly influence bioaccessibility. Mineral phase is an important determinant of lead and arsenic bioaccessibility as discussed in Ruby and others (1999). Similarly, it was demonstrated that copper bioaccessibility varies as a function of copper source mineral (Suzette Morman in Driscoll and others, 2012).

\section{Limitations of Results}

The results of this study are limited by several factors. Limited research has been conducted utilizing these simulated fluids to examine other exposure pathways, such as inhalation. Further, no uptake studies have been conducted to compare how accurately the SLF and SPF mimic the complex physiological processes of the lung. IVBA results express the amount of an element that is available to the body for uptake by target organs such as the kidneys and liver; actual uptake is as yet undetermined. Many physiological factors control the uptake of elements by the body. To date, no reference values delineating high or low levels of bioaccessibility and the correlation or relative bioavailability with uptake or bioavailability have been established for metals other than lead. Finally, the minerals studied in this investigation were ground, artificially creating fresh reactive surfaces. Unlike naturally occurring minerals present in soil matrices and lacking the additional solubility controls present in such matrices (that is, soil $\mathrm{pH}$, presence of organic carbon, clays, and iron or manganese oxides whose surfaces might sorb released metals), fresh surfaces may produce artificially high solubility values for some trace metals. 


\section{Summary}

Variations in trace-metal bioaccessibility are related to mineral species or extraction solution $\mathrm{pH}$, or both, for these samples. Ruby and others (1999) have focused on understanding aspects of the soil matrix to identify factors that influence bioaccessibility. Fewer studies have evaluated the effects of variable mineralogy. However, Schaider and others (2007) observed that zinc bioaccessibility was greater in zinc carbonates than zinc sulfides in size-fractionated mine-waste samples. The results described here help characterize the bioaccessibility of zinc-bearing minerals and provide data of potential utility in modeling and understanding variations in zinc bioaccessibility. 


\title{
Procedure and Results of Metal Toxicity for Five Zinc Mineral Concentrates Using MetPLATE ${ }^{\mathrm{TM}}$
}

\author{
By LaDonna M. Choate
}

\section{Introduction}

Metals leached from minerals in the environment can be toxic to aquatic organisms. Metal bioavailability and aquatic toxicity are a complex function of water chemistry (Sunda and Guillard, 1976). Some factors that can affect metal toxicity include metal concentration, complexation by aqueous ligands, and competition with other cations $\left(\mathrm{Ca}^{2+}, \mathrm{Mg}^{2+}, \mathrm{Na}^{+}, \mathrm{K}^{+}\right.$, $\mathrm{H}^{+}$) for biological uptake. Determining the half-maximal effective concentration $\left(\mathrm{EC}_{50}\right)_{-}$ defined as the concentration that produces a response in 50 percent of the exposed organisms - due to the presence of metals can be expensive and time consuming if standard test organisms are used. It is advantageous to use a screening protocol to identify samples that may require more in-depth evaluation. MetPLATE ${ }^{\text {TM }}$ is an enzymatic bioassay kit that can be used to determine if leached minerals will release metal in concentrations that are toxic to Escherichia coli (E. coli) bacteria (Bitton and others, 1994). Toxicity for the MetPLATETM is defined as the inhibition of $\beta$-galactosidase enzyme production. Unstressed $E$. coli bacteria produce $\beta$-galactosidase that catalyzes the hydrolysis (fig. 41) of a colored chromogenic substrate (chlorophenol red- $\beta$-galactopyranoside) causing the experimental solution to change from yellow-orange to purple-red.

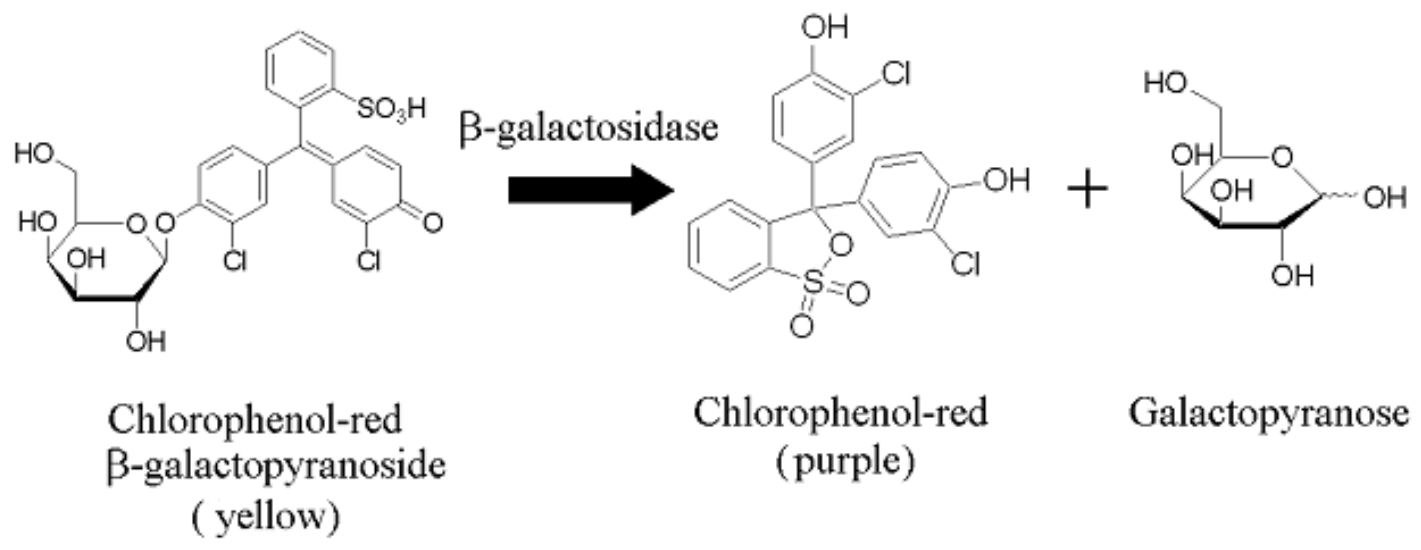

Figure 41. ß-galactosidase catalyzed hydrolysis of chlorophenol red-ß-galactopyranoside (Bitton and Koopman, 1997; Rossel and others, 1997; and Ward and others, 2005).

Bacteria stressed by the presence of metals produce less of the enzyme causing less of the colored chromogenic substrate to be hydrolyzed. Enzyme production inhibition is determined by comparison of the color (purple-red) of the sample, measured as absorbance at 575-nanometer (nm) wavelength, to that of a control having no inhibition. Figure 42 illustrates a developed MetPLATETM test. Each sample column represents an individual sample with varying concentrations of a toxic substance, in this case copper, but a similar response is found for zinc. The copper concentration decreases going down each column from rows A to $\mathrm{H}$. Inhibition (directly related to toxicity) decreases with decreasing metal concentration. The 
less toxic the sample, the darker the color of the experimental fluid and the higher the measured absorbance. Relative absorption is used to determine the $\mathrm{EC}_{50}$ for E. coli.

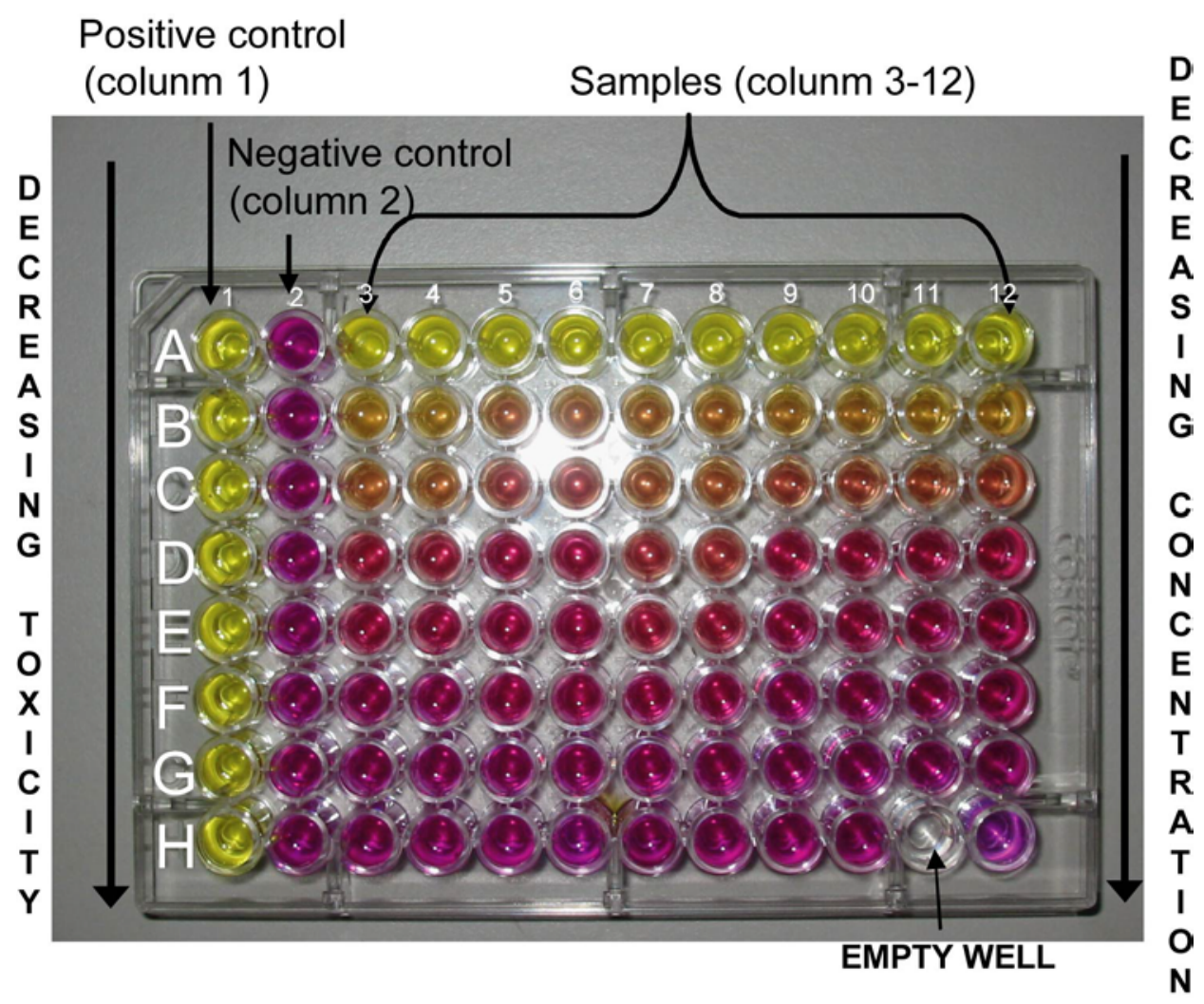

Figure 42. A developed 96-well MetPLATE ${ }^{\mathrm{TM}}$ bioassay showing negative (toxic) and positive (nontoxic) controls and dilution series for several water samples.

\section{General Method}

The MetPLATETM test kit, produced by M2B Research and Innovative Technologies (Gainesville, Fla.), is refrigerated until the day of use when it is removed and allowed to warm to room temperature. Mineral-concentrate samples were leached using the U.S. Geological Survey field leach test (USGS-FLT), 5-minute version (Hageman, 2007a). Twenty to fifty mL of the leachate (USGS-FLT solution) was evaluated using the MetPLATETM toxicity test. Dilutions were prepared by adding $10 \mathrm{~mL}$ of diluent (EPA moderately hard water; USEPA, 1994) to $10 \mathrm{~mL}$ of the USGS-FLT solution, obtained from P. Hageman, and vortexing for 10 seconds. Subsequent dilutions were prepared using this procedure (beginning with the previous dilution) until the required set of samples was obtained. Samples to be evaluated were prepared by transferring a $0.9-\mathrm{mL}$ aliquot of the undiluted sample and each of the dilutions into test tubes and adding $0.1 \mathrm{~mL}$ of the reconstituted bacterial reagent $(E$. coli). The controls were prepared by adding $0.1 \mathrm{~mL}$ of bacterial reagent to test tubes containing $0.9 \mathrm{~mL}$ of diluent for the negative control and $0.9 \mathrm{~mL}$ of the MetPLATE ${ }^{\mathrm{TM}}$ for positive control (copper sulfate solution at toxic levels). All sample tubes were vortexed for 10 seconds and incubated at $35^{\circ} \mathrm{C}$ for 90 minutes. After incubation, $0.2 \mathrm{~mL}$ of sample was transferred by pipette into the corresponding well in the 96-well microplate (fig. 42) and $0.1 \mathrm{~mL}$ of the 
reconstituted chromogenic substrate was added to each well. All samples were run in duplicate or triplicate.

Microplates were incubated at $35^{\circ} \mathrm{C}$, and the absorbance measured at $575 \mathrm{~nm}$ every 15 minutes over the course of 2 hours, using a BIO-TEK PowerWave350X spectrophotometer with KCjunior software. When the absorbance for the most dilute sample is approximately equal to the negative control, the corresponding time interval is used to determine the $\mathrm{EC}_{50}$ for the sample. The positive control has the maximum effect -100 percent inhibition of $\beta-$ galactosidase production - and should exhibit zero absorbance. However, the nonhydrolyzed chromogenic substrate has some color and produces an absorbance value. If the resulting absorbance values do not span the range between the positive and negative controls, then the sample is re-tested using more or less dilute sample to increase the absorbance spread. The absorbance for all concentrations has been corrected for maximum toxicity by subtracting the absorbance of the positive control.

The percent inhibition is calculated for each sample using the following equation:

$$
\% \text { inhibition }=(1-(\text { sample absorbance }) /(\text { control absorbance })) \times 100
$$

In some cases, the control absorbance of the most dilute sample is greater than the absorbance of the negative control. These leachate matrices probably contain other elements/compounds that enhance their absorbance at $575 \mathrm{~nm}$. Accordingly, the highest absorbance for the leachate is used as the control absorbance to account for this matrix effect. A plot of metal concentration versus percent inhibition indicates the metal concentration at which half of the $E$. coli is affected $\left(\mathrm{EC}_{50}\right)$.

\section{Summary}

The $\mathrm{pH}$ for all of the 100-percent USGS-FLT solutions were greater than or equal to 6.1, which is compatible with MetPLATETM applicability for use with $\mathrm{pH} 5.0$ to 7.5 solutions. Although the $\mathrm{pH}$ of the 100-percent hemimorphite USGS-FLT solution was 7.7, the $\mathrm{pH}$ of this solution was not adjusted, and the results are considered to be reasonably accurate despite the $\mathrm{pH}$ being slightly in excess of the MetPLATE ${ }^{\mathrm{TM}}$ specifications. Leachates derived from the five zinc mineral concentrates yield a wide array of toxicity, as shown in figures $43-45$. The maximum zinc concentration for the hemimorphite is less than 50-percent inhibition for the USGS-FLT solution and its dilutions (fig. 43) and precludes determination of the $\mathrm{EC}_{50}$ for this sample. The low zinc concentration produced in the hemimorphite mineral-concentrate leach limits its inhibition effect. 


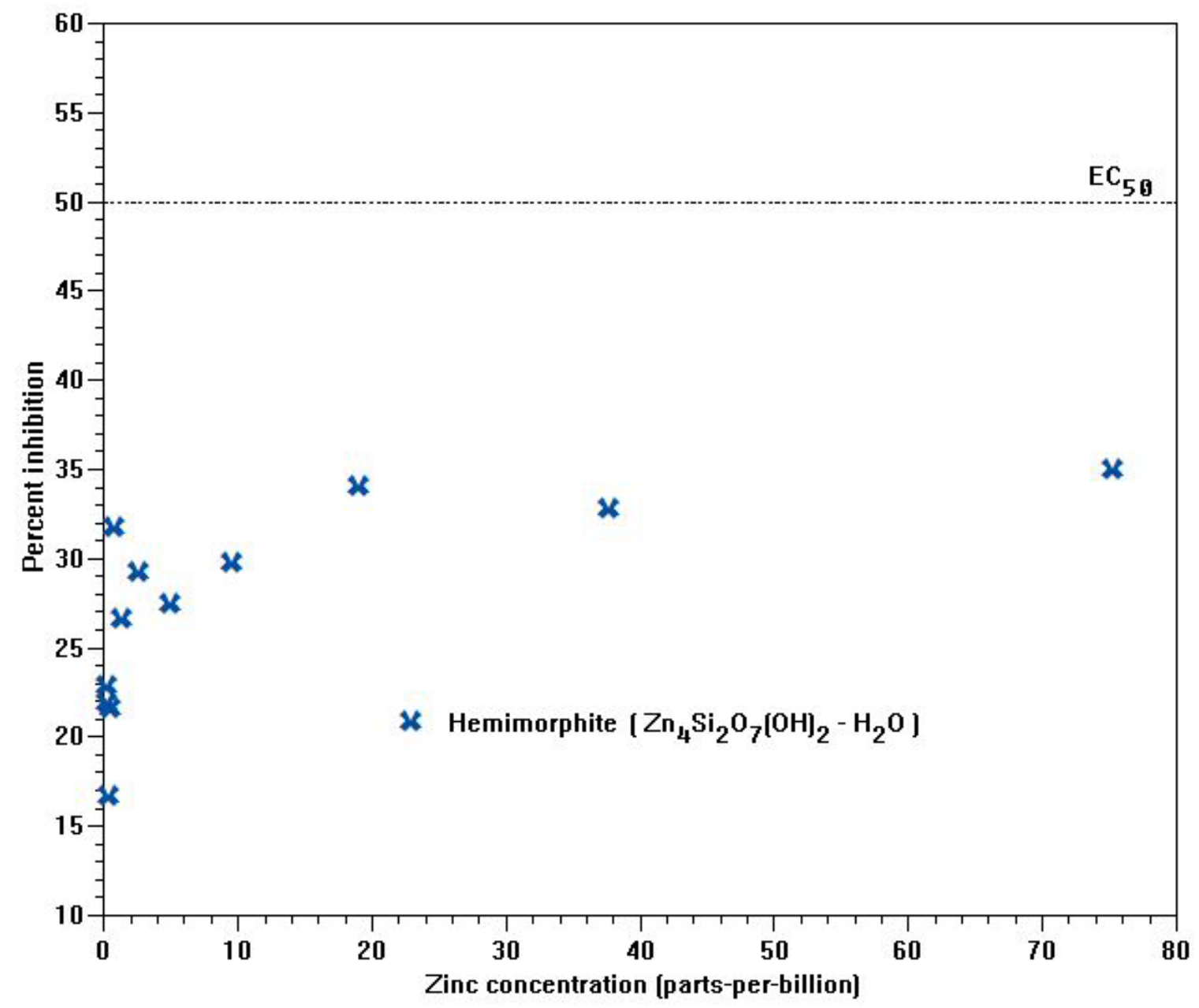

Figure 43. Percent inhibition of serial dilutions of the U.S. Geological Survey field leach test solution compared to the zinc concentrations (in micrograms per liter) for the mineral hemimorphite. $\mathrm{EC}_{50}$, half-maximal effective concentration. 


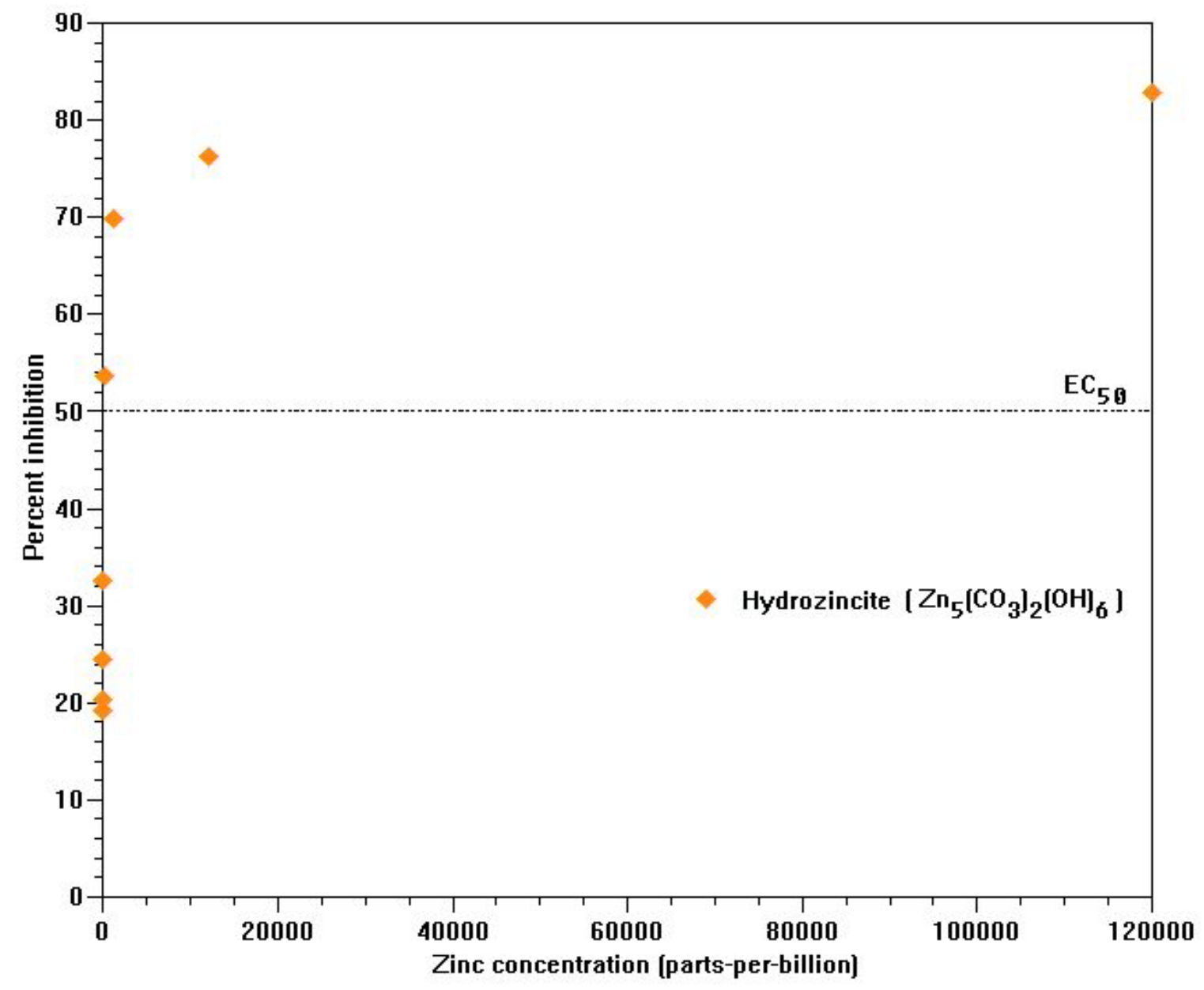

Figure 44. Percent inhibition of serial dilutions of the U.S. Geological Survey field leach test solution compared to the zinc concentrations (in micrograms per liter) for the mineral hydrozincite. $E C_{50}$, half-maximal effective concentration. 


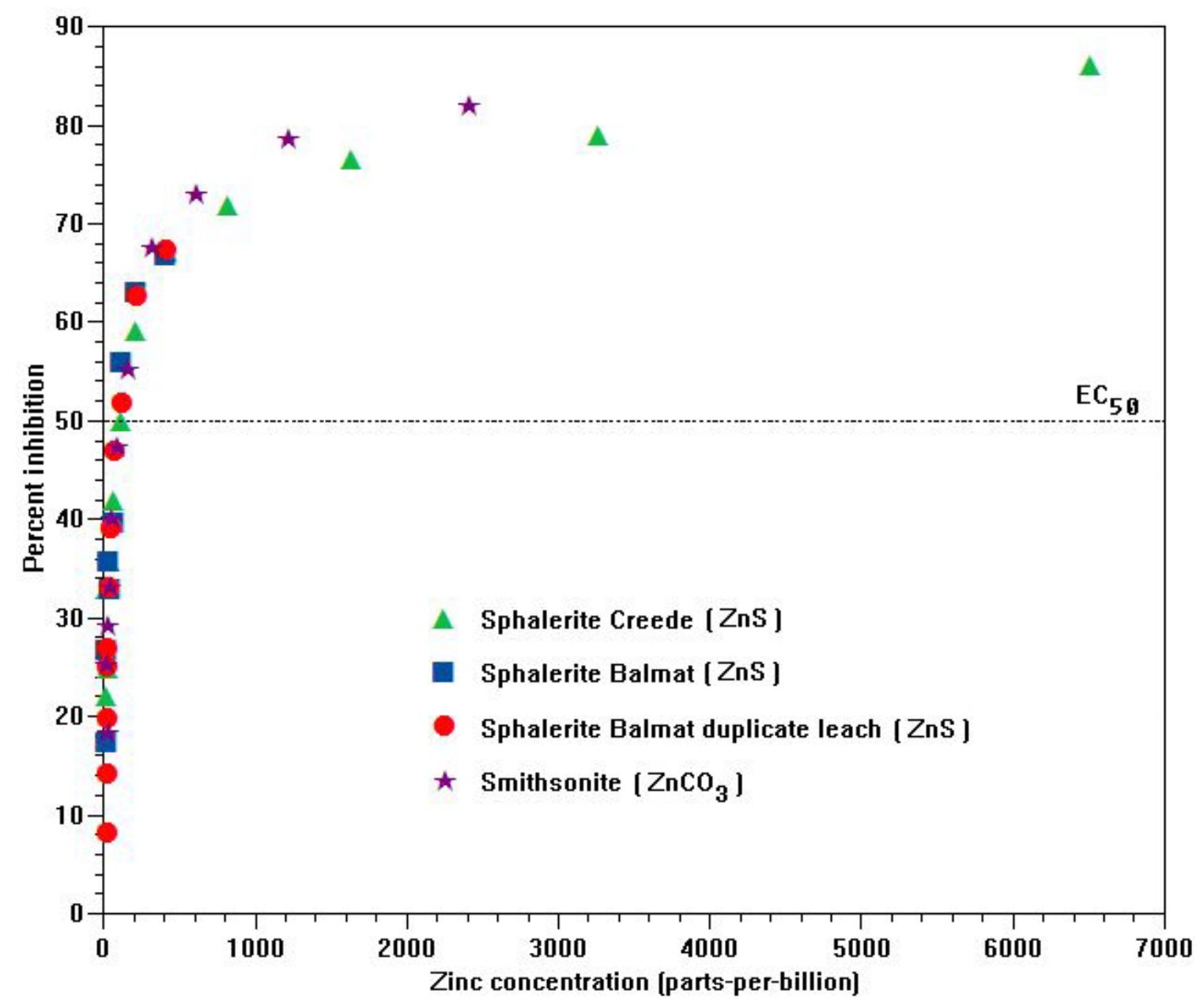

Figure 45. Percent inhibition of serial dilutions of the U.S. Geological Survey field leach test solutions compared to the zinc concentrations (in micrograms per liter) for the minerals smithsonite, sphalerite (Balmat, New York), and sphalerite (Creede, Colorado). EC 50 , half-maximal effective concentration.

Enzyme production inhibition is greater than 50 percent for the 100-percent USGSFLT solution and the next several most-concentrated dilutions produced from the hydrozincite USGS-FLT leachates (fig. 44) and the smithsonite and sphalerite samples (fig. 45). Due to the high concentration of zinc $(120,000$ micrograms per liter $(\mu \mathrm{g} / \mathrm{L}))$ in the USGS-FLT for hydrozincite, a dilution factor of 1:10 was used to obtain a range to calculate the $\mathrm{EC}_{50}$.

The Balmat sphalerite was leached in duplicate (fig. 46), and each leach was analyzed in triplicate allowing determination of the error for the analyses. An evaluation of the original Balmat sphalerite leachate data (fig. 46) indicates that the two datasets are statistically indistinguishable; all of these data were combined to determine the $\mathrm{EC}_{50}$ value for the Balmat sphalerite mineral concentrate. 


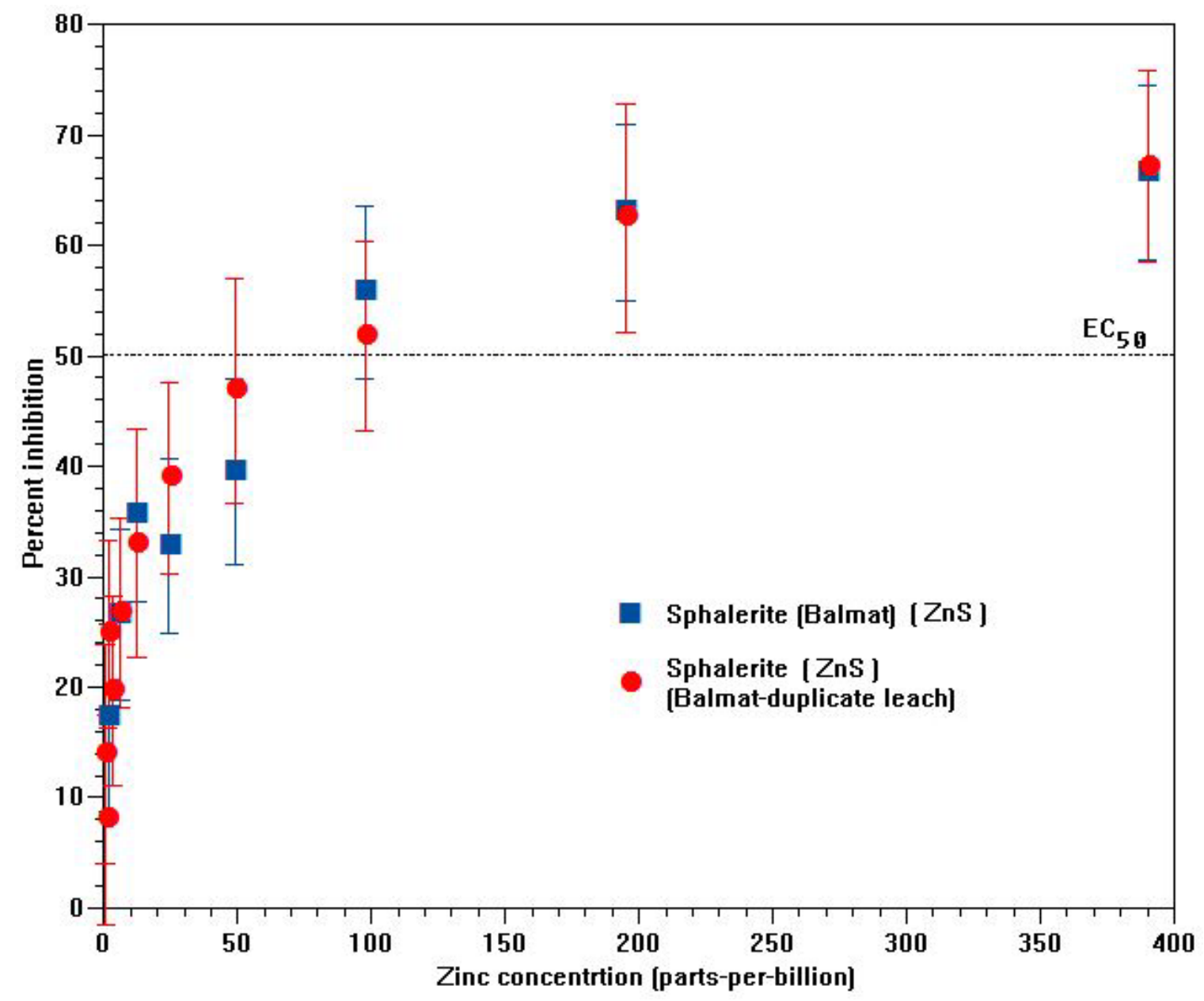

Figure 46. Percent inhibition of serial dilutions of the U.S. Geological Survey field leach test solution compared to the zinc concentrations (in micrograms per liter) for duplicate leaches of sphalerite (Balmat, New York). EC $\mathrm{C}_{50}$, half-maximal effective concentration.

$\mathrm{EC}_{50}$ for each of the five mineral-concentrate USGS-FLT leachate solutions was determined by fitting a logarithmic curve through five or more points (the number of points depended on obtaining the best fit) around 50-percent inhibition and determining the zinc concentration at the intersection of the fitted curve with the 50-percent inhibition line (figs. 47 and 48). 


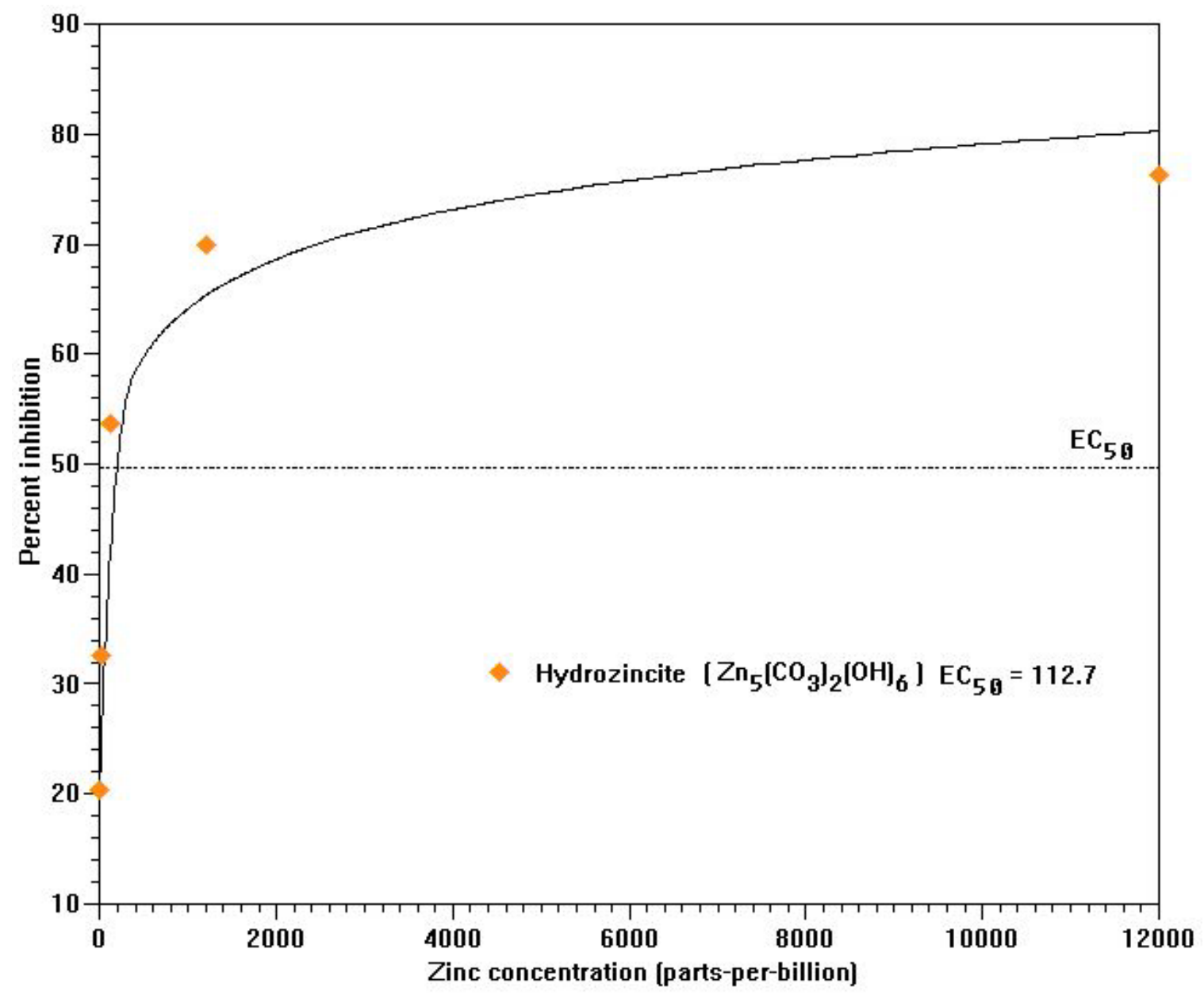

Figure 47. Percent inhibition of serial dilutions of the U.S. Geological Survey field leach test solution compared to the zinc concentrations (in micrograms per liter) for the mineral hydrozincite; the five dilutions nearest 50-percent inhibition with the fitted logarithmic curve. $\mathrm{EC}_{50}$, half-maximal effective concentration. 


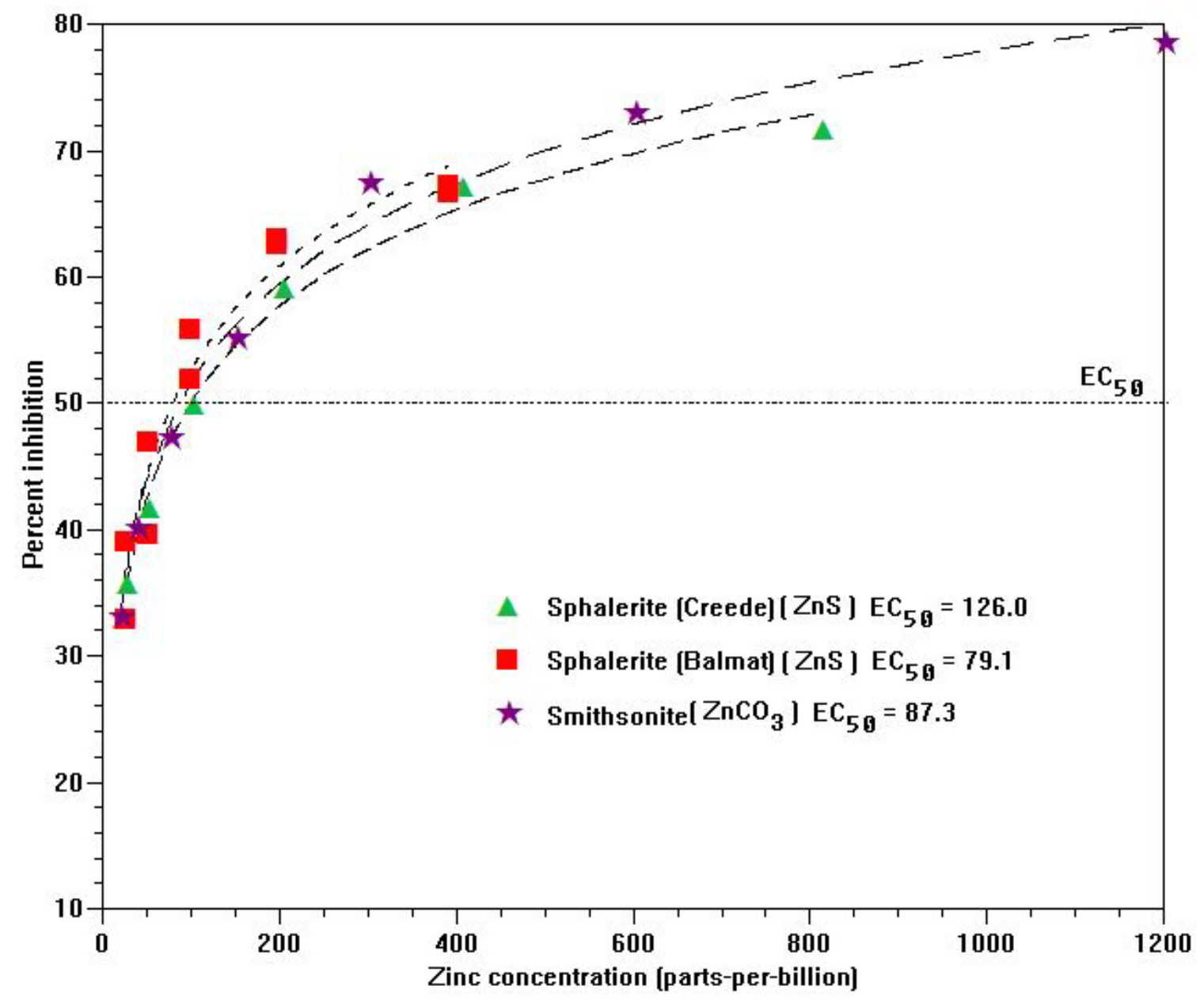

Figure 48. Percent inhibition of serial dilutions of the U.S. Geological Survey field leach test solution compared to the zinc concentrations (in micrograms per liter) for the minerals smithsonite, sphalerite (Balmat, New York), and sphalerite (Creede, Colorado); the 7 (smithsonite), 6 (sphalerite (Creede)), or 10 (sphalerite (Balmat)) dilutions nearest 50-percent inhibition with the fitted logarithmic curve. $\mathrm{EC}_{50}$, half-maximal effective concentration.

Tabulated inhibition results may not reflect the effect of zinc alone. The observed inhibition may be enhanced or diminished by other metals and constituents derived from the five mineral-concentrate leachates (table 4). 
Table 4. Summary of the $\mathrm{EC}_{50}$ (half-maximal effective concentration) values and 100-percent leachate concentrations for zinc, cadmium, lead, calcium, magnesium, sulfate chlorine, and pH (from $\mathrm{P}$. Hageman, this volume) for five zinc-bearing minerals and diluent.

$\left[\mathrm{nc}=\right.$ no chronic toxicity at the leach concentration; $\mathrm{EC}_{50}$ is outside of the concentration range. $\mu \mathrm{g} / \mathrm{L}$, micrograms per liter; $\mathrm{mg} / \mathrm{L}$, milligrams per liter]

\begin{tabular}{|c|c|c|c|c|c|c|}
\hline Mineral $\rightarrow$ & Diluent & $\begin{array}{c}\text { Hemimorphite } \\
\mathrm{Zn}_{4} \mathrm{Si}_{2} \mathrm{O}_{7}(\mathrm{OH})_{2}- \\
\mathrm{H}_{2} \mathrm{O}\end{array}$ & $\begin{array}{l}\text { Hydrozincite } \\
\mathrm{Zn}_{5}\left(\mathrm{CO}_{3}\right)_{2}(\mathrm{OH})_{6}\end{array}$ & $\begin{array}{l}\text { Smithsonite } \\
\mathrm{ZnCO}_{3}\end{array}$ & $\begin{array}{c}\text { Sphalerite } \\
\text { (Balmat) } \\
\text { ZnS }\end{array}$ & $\begin{array}{c}\text { Sphalerite } \\
\text { (Creede) } \\
\text { ZnS }\end{array}$ \\
\hline $\begin{array}{l}\mathrm{EC}_{50} \\
(\text { Zinc } \mu \mathrm{g} / \mathrm{L})\end{array}$ & na & $\mathrm{nc}$ & 112.7 & 87.3 & 79.1 & 126.0 \\
\hline \multicolumn{7}{|l|}{$\begin{array}{c}\text { 100-percent leachate } \\
\text { concentration } \\
\downarrow\end{array}$} \\
\hline Zinc $\mu \mathrm{g} / \mathrm{L}$ & & 75 & 120000 & 2400 & 390 & 6500 \\
\hline Cadium $\mu \mathrm{g} / \mathrm{L}$ & & 25 & 1300 & 43 & 0.12 & 16 \\
\hline Lead $\mu \mathrm{g} / \mathrm{L}$ & & 0.3 & 430 & 21 & 1.7 & 140 \\
\hline Calcium mg/L & 7.0 & 2.7 & 240 & 1.4 & $<0.1$ & 0.53 \\
\hline Magnesium mg/L & 6.1 & $<0.1$ & 15 & 0.13 & $<0.1$ & 0.18 \\
\hline Sulfate $\left(\mathrm{SO}_{4}^{-2}\right) \mathrm{mg} / \mathrm{L}$ & & $<1$ & 41 & $<1$ & $<1$ & 9.3 \\
\hline $\mathrm{pH}$ & 7.6 & 7.7 & 6.6 & 7.1 & 7.2 & 6.1 \\
\hline
\end{tabular}

The $\mathrm{EC}_{50}$ for the hemimorphite mineral concentrate is indeterminate because the derived leachate concentration for zinc does not produce inhibition for 50 percent or more of the organisms. Determined $\mathrm{EC}_{50}$ zinc values for the hydrozincite $(112.7 \mu \mathrm{g} / \mathrm{L})$ and the Creede sphalerite $(126.0 \mu \mathrm{g} / \mathrm{L})$ are higher (table 4$)$ than the $\mathrm{EC}_{50}$ determined for smithsonite $(87.3$ $\mu \mathrm{g} / \mathrm{L})$ and the Balmat sphalerite $(79.1 \mu \mathrm{g} / \mathrm{L})$. The 100-percent leachate derived from the hydrozincite and the Creede sphalerite mineral concentrates contain significant sulfate, which may form soluble complexes with the zinc; both leachates also contain calcium and magnesium that can compete and limit the uptake of zinc. The reduction of inhibition due to the competition of calcium and magnesium with zinc may have increased the $\mathrm{EC}_{50}$ for the hydrozincite mineral concentrate; since 1:10 dilutions were required to achieve the necessary range, the concentration of calcium (7 milligrams per liter $(\mathrm{mg} / \mathrm{L}))$ and magnesium $(6.1 \mathrm{mg} / \mathrm{L})$ in the diluent are important because they can compete with zinc for uptake by the organism. The carbonate molecule can form soluble complexes with the zinc and is a significant constituent of smithsonite; also, the leachate contains significant amounts of calcium and magnesium reducing the zinc uptake and increasing the $\mathrm{EC}_{50}$.

Determined $\mathrm{EC}_{50}$ values for the five minerals are similar, which suggests that replicate MetPLATE ${ }^{\mathrm{TM}}$ analyses should be performed to determine if the $\mathrm{EC}_{50}$ values are statistically different. In order to more broadly establish the toxicity of leachates derived from the five zinc mineral concentrates, additional toxicity tests using an array of different aquatic species should be conducted to determine the $\mathrm{EC}_{50}$ for additional organisms.

\section{Conclusion}

Metallic zinc is used in the production of alloys and as a coating for iron and steel structures to prevent corrosion in most atmospheres (Zinc Information Center, 2012). Zinc oxide is used as an additive in rubber, ceramics, various chemicals, paints, and pharmaceuticals (International Zinc Association, 2012). 
As a discrete element, zinc poses almost no risk to human health or the natural environment; the World Health Organization recommends pure zinc supplementation for severe malnutrition, diarrhea, and disease prevention, and to reduce premature mortality in poor, underdeveloped countries (WHO, 2006). The U.S. Environmental Protection Agency classifies zinc as a nuisance element, one that may produce an unpleasant odor or metallic taste in water but is otherwise neutral, or nontoxic (USEPA, 2006). Neutrality though, as this assessment demonstrated, is not characteristic of zinc-bearing minerals.

Findings presented in this volume demonstrate that the selected zinc-bearing minerals contain significant cadmium and lead. As revealed by Benzel and Diehl (this volume), hydrozincite contains lead as a replacement element and both lead and cadmium as surficial carbonate precipitates. The authors suggest that the precipitates are susceptible to dissolution and discharge of primary metals. Through a series of chemical analyses and leach tests, Hageman (this volume) confirmed the presence of lead and cadmium in the hemimorphite sample; his FLT test produced a $\mathrm{pH}$ value for hemimorphite of 9.20-evidence of the solubility and subsequent migration of acid-producing heavy metals. The simulated extraction fluid studies demonstrated that cadmium and lead, present in all of the study minerals, are not only soluble in all experimental biological fluids, but are readily absorbed, or bioaccessible, in acidic bio-environments, such as the stomach. The results of the toxicity study suggest that elevated levels of lead and cadmium, as well as other metals, may inhibit production of a critical reproduction enzyme.

These elements, if liberated from the mineral structure (through either artificial processes such as mining or smelting, or through a natural process like water infiltration), have the potential to compromise the health of most living organisms. Cadmium, particularly, is an element of concern. The EPA classifies cadmium as a probable human carcinogen, and both the International Agency for Research on Cancer and the National Toxicity Program classify cadmium as a known human carcinogen (ATSDR, 2008). Lead, also recognized as a toxic metal, contributes to fine-motor-function deficits, increased blood pressure, cataracts, and cognitive impairment (NIEHS, 2012). Both of these elements were detected in the studied zinc minerals.

Although zinc is the dominant metal in these minerals, the abundance and toxicity of soluble cadmium and lead suggest that rocks that contain appreciable quantities of zinc minerals pose a significant health risk and that exposure to common zinc-bearing minerals should be limited and (or) regulated.

\section{References Cited}

Agency for Toxic Substances and Disease Registry (ATSDR), 2008, Case studies in environmental medicine: ATSDR, Cadmium toxicity, p. 17, accessed August 30, 2012, at http://www.atsdr.cdc.gov/csem/cadmium/docs/cadmium.pdf.

Al-Abed, S.R., Hageman, P.L., Jegadeesan, G., Madhavan, N., and Allen, D., 2005, Comparative evaluation of short-term leach tests for heavy metal release from mineral processing waste: Science of the Total Environment, v. 364, p. 14-23.

Ansoborlo, E., Henge-Napoli, M.H., Chazel, V., Gilbert, R., and Guilmette, R.A., 1999, Review and critical analysis on available in vitro dissolution tests: Health Physics, v. 77, no. 6, p. 638-645.

Basta, N.T., Foster, J.N., Dayton, E.A., Rodriguez, R.R., and Casteel, S.W., 2007, The effect of dosing vehicle on arsenic bioaccessibility in smelter-contaminated soils: Journal of Environmental Science and Health, Part A, v. 42, no. 9, p. 1275-1281. 
Belsky, A.H., 2002, New developments in the inorganic crystal structure database (ICSD) accessibility in support of materials research and design: Acta Crystallography, v. B58., p. 364-369. (See appendix 1.)

Benedetto, F.B., 2005, Compositional zoning in sphalerite crystals: American Mineralogist, v. 90, p. 1384-1392.

Bitton, G., Jung, K., and Koopman, B., 1994, Evaluation of a microplate assay specific for heavy metal toxicity: Archives of Environmental Contamination and Toxicology, v. 27, p. 25-28.

Bitton, G., and Koopman, B., 1997, Assay pad and method for determination of the presence of total coliforms: United States Patent and Trademark Office, Patent 5633144, filed 7/19/1994.

Briggs, P.H., 2002, The determination of twenty-seven elements in aqueous samples by inductively coupled plasma-atomic emission spectrometry, chap. F of Taggart, J.E., Jr., ed., Analytical methods for chemical analysis of geologic and other materials: U.S. Geological Survey Open-File Report 02-223, available at http://pubs.usgs.gov/of/2002/ofr-02-0223/.

Briggs, P.H., and Meier, A.L., 2002, The determination of forty-two elements in geological materials by inductively coupled plasma-mass spectrometry, chap. I of Taggart, J.E., Jr., ed., Analytical methods for chemical analysis of geological and other materials: U.S. Geological Survey Open-File Report 02-223, available at http://pubs.usgs.gov/of/2002/ ofr-02-0223/.

Brown, Z.A., and Curry, K.J., 2002a, Total carbon by combustion, chap. R of Taggart, J.E., Jr., ed., Analytical methods for chemical analysis of geologic and other materials: U.S. Geological Survey Open-File Report 02-223, available at http://pubs.usgs.gov/of/2002/ ofr-02-0223\%.

Brown, Z.A., and Curry, K.J., 2002b, Total sulfur by combustion, chap. Q of Taggart, J.E., Jr., ed., Analytical methods for chemical analysis of geologic and other materials: U.S. Geological Survey Open-File Report 02-0223, available at http://pubs.usgs.gov/of/2002/ ofr-02-0223/.

Brown, Z.A., Papp, C., Brandt, E., and Aruscavage, P., 2002, Carbonate carbon by coulometric titration, chap. S of Taggart, J.E., Jr., ed., Analytical methods for chemical analysis of geologic and other materials: U.S. Geological Survey Open-File Report 02-223, available at http://pubs.usgs.gov/of/2002/ofr-02-0223/.

Brumbaugh, W.G., and Morman, S.A., 2011, Concentrations and bioaccessibility of metals in vegetation and dust near a mining haul road, Cape Krusenstern National Monument, Alaska: Environmental Monitoring and Assessment., v. 182, issue 1-4, p. 325-340.

Diehl, S.F., Hageman, P.L., and Smith, K.S., 2006, What's weathering? Mineralogy and field leach studies in mine waste, Leadville and Montezuma mining districts, Colorado, in Proceedings of the Seventh International Conference on Acid Rock Drainage (ICARD 7), St. Louis, Missouri, March 26-30, 2006: Lexington, Ky., American Society of Mining and Reclamation (ASMR), p. 507-527, available at http://www.imwa.info/docs/imwa_2006/0507-Diehl-CO.pdf.

Diehl, S.F., Hageman, P.L., Smith, K.S., Koenig, A.E., Fey, D.L., and Lowers, H.A., 2007, What's weathering in mine waste? Mineralogic evidence for sources of metals in leachates, in Proceedings of the Hard Rock 2006 Conference, Tucson, Ariz., November 14-16, 2006: U.S. Environmental Protection Agency, Interactive Hard Rock Mining 2006 Conference CD-ROM (EPA/625/C-07/003). 
Diehl, S.F., Benzel, W.M., Hageman, P.L., Lowers, H.L., Driscoll, R.L., and Seal, R.R., II, 2012, Microanalytical techniques to understand element leaching from ore minerals in mining wastes, in Hardrock Mining Conference 2012, Denver, Colo., April 3-5, 2012: U.S. Environmental Protection Agency, Advancing Solutions for a New Legacy.

Drexler, J.W., and Brattin, W.J., 2007, An in vitro procedure for estimation of lead relative bioavailability_-With validation: Human and Ecological Risk Assessment, v. 13, p. 383-401.

Driscoll, R., Hageman, P.L., Benzel, W.M., Diehl, S.F., Adams, D.T., Morman, Suzette, and Choate, L.M., 2012, Assessment of the geoavailability of trace elements from minerals in mine wastes-Analytical techniques and assessment of selected copper minerals: U.S. Geological Survey Scientific Investigations Report 2011-5211, 68 p., available at http://pubs.usgs.gov/sir/2011/5211/.

Ettler, V., Kř́bek, B., Majer, V., Knésl, I., Mihaljevič, M., 2012, Differences in the bioaccessibility of metals/metalloids in soils from mining and smelting areas (Copperbelt, Zambia): Journal of Geochemical Exploration, v. 113 , p. 68-75.

Frost, R.L., Hales, M.C., and Wain, D.L., 2008, Raman spectroscopy of smithsonite: Journal of Raman Spectroscopy, v. 39, p. 108-114.

Gordon, T., and Fine, J.M., 1993, Metal fume fever: Occupational Medicine, v. 8, no. 3, p. 504-517.

Hageman, P.L., 2007a, U.S. Geological Survey field leach test for assessing water reactivity and leaching potential of mine wastes, soils, and other geologic and environmental materials: U.S. Geological Survey Techniques and Methods, book 5, chap. D3, 14 p., available at $h t t p: / / p u b s . u s g s . g o v / t m / 2007 / 05 D 03 /$.

Hageman, P.L., 2007b, Determination of mercury in aqueous and geologic materials by continuous flow-cold vapor-atomic fluorescence spectrometry (CVAFS): U.S. Geological Survey Techniques and Methods, book 5, chap. D2, 6 p., available at http://pubs.usgs.gov/tm/2007/05D02/.

Harper, K., and Griffen, D., 2005, Crystallographic consequences of Mn substitution in willemite, in Geologic Society America Conference Proceedings, Salt Lake City Annual Meeting, October 16-19, 2005 [abs.]: Geologic Society of America Abstracts with Programs, v. 37, p. 287.

Herting, G., Wallinder, O., and Leygraf, C., 2006, Factors that influence the release of metals from stainless steels exposed to physiological media: Corrosion Science, v. 48, p. 2120 2132.

International Zinc Association, 2012, Zinc oxide applications: International Zinc Association Web site, accessed August 30, 2012, at http://www.zinc.org/info/zinc_oxide_applications.

Kanapilly, G.M., Raabe, O.G., Goh, C.H.T., and Chimenti, R.A., 1973, Measurement of in vitro dissolution of aerosol particles for comparison to in vivo dissolution in the lower respiratory track after inhalation: Health Physics, v. 24, p. 497-507.

Kolesov, B., 2006, Raman investigation of $\mathrm{H}_{2} \mathrm{O}$ molecule and hydroxyl groups in the channels of hemimorphite: American Mineralogist, v. 91, p. 1355-1362.

Kreyling, W., 1992, Intracellular particle dissolution in alveolar macrophages: Environmental Health Perspectives, v. 97, p. 121-126.

Lamothe, P.J., Meier, A.L., and Wilson, S., 2002, The determination of forty-four elements in aqueous samples in inductively coupled plasma-mass spectrometry, chap. H of Taggart, J.E., Jr., ed., Analytical methods for chemical analysis of geologic and other materials: U.S. 
Geological Survey Open-File Report 02-0223, available at http://pubs.usgs.gov/of/2002/ ofr-02-0223/.

Lapakko, Kim, and Lawrence, R.W., 1993, Modifications of the net acid production (NAP) test: Proceedings of the Seventeenth Annual British Columbia Mine Reclamation Symposium, Port Hardy, British Columbia, 1993, p. 145-159.

Lattanzi, P., Maurizio, C., Meneghini, C., de Giudici, G., and Podda, F., 2010a, Uptake of Cd in hydrozincite, $\mathrm{Zn}_{5}\left(\mathrm{CO}_{3}\right)_{2}(\mathrm{OH})_{6}$-Evidence from X-ray absorption spectroscopy and anomalous X-ray diffraction: European Journal of Mineralogy, v. 22, p. 557-564.

Lattanzi, P., Maurizio, C., Meneghini, C., de Giudici, G., and Podda, F., 2010b, Uptake of Pb by hydrozincite, $\mathrm{Zn}_{5}\left(\mathrm{CO}_{3}\right)_{2}(\mathrm{OH})_{6}$ : Implications for remediation: Journal Hazardous Materials, v. 177, p. 1138-1144.

Mao, M., 2012, Nature of heavy metals in hemimorphite-A cation-exchange and single crystal EPR study: Canadian Mineralogist, v. 50, p. 31-43.

Markham, N., 1960, The willemite-hemimorphite relationship: Economic Geology, v. 55, p. $844-847$.

Morman, S., Plumlee, G.S., and Smith, D.B., 2009, Application of in vitro extraction studies to evaluate element bioaccessibility in soils from a transect across the United States and Canada: Applied Geochemistry, v. 24, no. 8, p. 1454-1463.

National Institute of Environmental Health Sciences, 2012, Lead: National Institute of Environmental Health Sciences Web site, accessed August 26, 2012, at http://www.niehs.nih.gov/health/topics/agents/lead/.

National Institutes of Health, 2011, Dietary supplement fact sheet: Zinc: National Institutes of Health Web site, accessed April 13, 2012, at http://ods.od.nih.gov/factsheets/ Zinc-HealthProfessional/.

Palache, C., Berman, H., and Frondel, C., 1961a, The system of mineralogy of James Dwight Dana and Edward Salisbury Dana, Yale University 1837-1892, Volume I (7th ed.): Wiley, p. 210-215.

Palache, C., Berman, H., and Frondel, C., 1961b, The system of mineralogy of James Dwight Dana and Edward Salisbury Dana, Yale University 1837-1892, Volume II (7th ed.): Wiley, p. 141-150, 176-180, and 247-248.

Podda, F.M., 2000, Heavy metal coprecipitation with hydrozincite $\left(\mathrm{Zn}_{5}\left(\mathrm{CO}_{3}\right)_{2}(\mathrm{OH})_{6}\right)$ from mine waters caused by photosynthetic microorganisms: Applied and Environmental Microbiology, v. 66, no. 11, p. 5092-5098.

Rosenblum, Sam, and Brownfield, I.K., 1999, Magnetic susceptibilities of minerals: U.S. Geological Survey Open-File Report 99-529, 37 p., available at http://pubs.usgs.gov/of/1999/0529/report.pdf.

Rossel, D., Tarradellas, J., Bitton, G., and Morel, J.L., 1997, Use of enzymes in soil ecotoxicology — A case for dehydrogenase and hydrolytic enzymes: Boca Raton, Fla., CRC Press, Soil Ecotoxicology, p. 179-206.

Roy, M., 1956, Stability of minerals in the system $\mathrm{ZnO}-\mathrm{SiO}_{2}-\mathrm{H}_{2} \mathrm{O}$ : Economic Geology, v. 51, p. 432-443.

Ruby, M.V., Davis, A., Link, T., Schoof, R., Chaney, R., Freman, G., Bergstrom, P., 1993, Development of an in vitro screening test to evaluate the in vivo bioaccessibility of ingested mine-waste lead: Environmental Science and Technology, v. 27, p. 2870-2875.

Ruby, M.V., Davis, A., Schoof, R., Eberle, S., Sellstone, C., 1996, Estimation of lead and arsenic bioavailability using a physiologically based extraction test: Environmental Science and Technology, v. 30, p. 422-430. 
Ruby, M.V., Schoof, R., Brattin, W., Goldade, M., Post, G., Harnois, M., Mosby, D.E., Casteel, S.W., Berti, W., Carpenter, M., Edwards, D., Cragin, D., and Chappell, W., 1999, Advances in evaluating the oral bioavailability of inorganics in soil for use in human health risk assessment: Environmental Science and Technology, v. 33, p. 3697-3705.

Schaider, L., Senn, D., Brabander, D., McCarthy, K., Shine, J., 2007, Characterization of zinc, lead, and cadmium in mine waste-Implications for transport, exposure, and bioavailability: Environmental Science and Technology, v. 41, p. 4164-4171.

Smith, K., 2007, Strategies to predict metal mobility in surficial mining environments: Reviews in Engineering Geology, v. 17, p. 25-45.

Standstead, H., and Au, W., 2007, Zinc: Amsterdam, Elsevier, Handbook on the Toxicology of Metals, p. 925-943.

Stefaniak, A., Day, G., Hoover, M., Breysse, P., and Scripsick, R., 2006, Differences in dissolution behavior in a phagolysosomal fluid for single constituent and multi-constituent materials associated with beryllium sensitization and chronic beryllium disease: Toxicology in Vitro, v. 20, p. 82-95.

Sun, G., Crissman, K., Norwood, J., Richards, J., Slade, R., and Hatch, G., 2001, Oxidative interactions of synthetic lung epithelial lining fluid with metal containing particulate matter: American Journal of Physiology Lung Cellular and Molecular Physiology, v. 281, p. $807-815$.

Sunda, W.G., and Guillard, R.R.L., 1976, The relationship between cupric ion activity and the toxicity of copper to phytoplankton: Journal of Marine Research, v. 34, p. 511-529.

Theodorakos, P.M., d'Angelo, W.M., and Ficklin, W.H., 2002, Fluoride, chloride, nitrate, and sulfate in aqueous solution utilizing AutoSupression chemically suppressed ion chromatography, chap. V of Taggart, J.E., Jr., ed., Analytical methods for chemical analysis of geologic and other materials: U.S. Geological Survey Open-File Report 02-0223, p. V-1-V-7, available at http://pubs.usgs.gov/of/2002/ofr-02-0223/.

Theodorakos, P.M., 2002, Determination of total alkalinity using a preset endpoint ( $\mathrm{pH} 4.5)$ auto titration system, chap. E of Taggart, J.E., Jr., ed., Analytical methods for chemical analysis of geologic and other materials: U.S. Geological Survey Open-File Report, 02 0223, p. E-1-E-3, available at http://pubs.usgs.gov/of/2002/ofr-02-0223/.

U.S. Environmental Protection Agency (USEPA), 1994, Short-term methods for estimating chronic toxicity of effluents and receiving water to freshwater organisms: U.S. Environmental Protection Agency 841-S-94-004, November 1994, available at http://water.epa.gov/scitech/methods/cwa/wet/intro.cfm.

U.S. Environmental Protection Agency (USEPA), 2004, Test methods for evaluating solid wastes, physical/chemical methods: U.S. Environmental Protection Agency SW-846, revision 6, November 2004, accessed February 12, 2008, at http://www.epa.gov/osw/hazard/testmethods/sw846/pdfs/1311.pdf.

U.S. Environmental Protection Agency (USEPA), 2006, Secondary drinking water regulations, in Guidance for nuisance chemicals: U.S. Environmental Protection Agency Web site, accessed August 8, 2012, at http://water.epa.gov/drink/contaminants/secondarystandards.cfm.

U.S. Environmental Protection Agency (USEPA), 2008, Standard operating procedure for an in vitro bioaccessibility assay for lead in soil: U.S. Environmental Protection Agency 9200.1-86, November 2008, available at http://www.epa.gov/superfund/bioavailability/pb_ivba_sop_final.pdf. 
Van Wijnen, J.H., Clausing, P., and Brunekreef, B., 1990, Estimated soil ingestion by children: Environmental Research, v. 51, p. 147-162.

Ward, M.L., Bitton G., and Townsend T., 2005, Heavy metal binding capacity (HMBC) of municipal solid waste landfill leachates: Chemosphere, v. 60, p. 206-215.

World Health Organization (WHO), 2006, The impact of zinc supplementation on childhood mortality and severe morbidity: World Health Organization Workshop, Geneva, Switzerland, September 15-16, 2006, 11 p., available at http://www.who.int/maternal_child_adolescent/documents/zinc_mortality/en/index.html.

Young, R., 1995, The Rietveld method: New York, University Press, International Union of Crystallography Monographs no. 5, 289 p. (See appendix 1.)

Zinc Information Center, 2012, Applications: Zinc Information Center Web site, accessed September 4, 2012, at http://www.zincinfocentre.org. 


\section{Appendix A}

\section{Panalytical X'PERT X-ray Diffractometer Instrument Set-Up}

The following instrument conditions were used to collect scan data:

- $\quad$ voltage $(\mathrm{kV})$

- $\quad$ current (mA)

- $\quad$ scan range $\left({ }^{\mathrm{o}} 2 \theta\right)$

- step

- $\quad$ seconds per step

- $\quad$ tube divergence slit

- tube scatter slit

- detector scatter slit

- detector reference slit
5 to $90^{\circ} 2 \theta$

$0.0167^{\circ} 2 \theta$

5

$2^{\circ}$

$4^{\circ}$

$0.5^{\circ}$

$0.2^{\circ}$

- $\quad$ strip detector with an active area of 127 points in $2.12^{\circ} 2 \theta$

The Panalytical X'Pert X-ray diffractometer was calibrated using National Institute of Standards and Technology Silicon x-ray Diffraction standard SRM 640. The calibration involves measuring the full width half maximum (FWHM) of the silicon standard over full scan range of the instrument, 0 to $90^{\circ} 2 \theta$ for the Scintag. The line broadening and goniometer aberrations are plotted to create a calibration curve specific to each instrument. The dataprocessing software described below uses this calibration to correct the measured sample scans.

In general, XRD has a detection limit of approximately 3 weight percent. Highly crystalline minerals have a lower detection limit (approximately 1-3 percent) and poorly crystalline minerals have a higher detection limit (approximately $3-5$ percent). Amorphous materials do not produce unique reflections; however, they do contribute to the background intensity of the scan, which allows an estimate to be made of the total amorphous content.

\section{Data Processing}

First, the observed pattern, or data, is acquired from the XRD instrument. X-ray powder diffraction scans were reviewed for mineral phases present in each specimen. Mineral phases are identified in a scan by comparing observed reflections, both two-theta position and intensity, with reference standards. Mineral databases from the International Center for Diffraction Data (ICDD) and the National Institute of Standards and Technology Inorganic Crystal Structure Database (ICSD) (Belsky, 2002) were used to search for phases. Once all the reflections are assigned to mineral phases, the data was analyzed using Jade Whole Pattern 
Fit Analyses software (WPF v.9.0.0). With the Jade software, whole pattern fitting of the observed data and Rietveld refinement of crystal structures are performed simultaneously (Young, 1995).

\section{Limitations of the data}

The WPF software normalizes the data to 100 percent for all identified phases. The typical detection limit by X-ray diffraction is between 1 and 3 weight percent, depending on the crystallinity of the phase and interference from overlapping lines from other phases. Thus, there may be trace phases present, but not identified, and they are not included in the model. Furthermore, the amorphous content is calculated based on the internal standard. Any error introduced by grinding and blending that alters the weight ratio of the sample to internal standard will yield anomalous amorphous content, which in turn will be carried forward into the normalization and effect the mineral contents.

The WPF software calculates the unit cell for phases selected by the user. The unit cell (or lattice parameter) calculation produces the best results for major components because the XRD scan includes sufficient information (reflections and intensity). Minor and trace components having less intensity and often weak reflections do not show up in the scan. Lastly, as the number of phases increase in the sample, the line overlap (interference) increases, which reduces the accuracy of the unit-cell calculation.

\section{Appendix B}

Complete bulk geochemistry results for five zinc-bearing minerals.

Appendix B. Bulk chemical composition of five zinc minerals.

[All results by inductively coupled plasma-mass spectrometry except mercury (cold-vapor atomic fluorescence), and total carbon and total sulfur by LECO; na = not analyzed; $<=$ less than; $\mathrm{mg} / \mathrm{L}=$ milligrams per liter; $\mu \mathrm{S} / \mathrm{cm}=\mathrm{micro}$ Siemens per centimeter; $\mathrm{mg} / \mathrm{kg}=$ milligrams per kilogram; wt. $\%=$ weight percent $]$

\begin{tabular}{|c|c|c|c|c|c|c|c|c|c|}
\hline Mineral & $\mathrm{Ag}$ & $\mathrm{Al}$ & As & $\mathrm{Ba}$ & $\mathrm{Be}$ & $\mathrm{Bi}$ & $\mathrm{CO}_{2}$ & $\begin{array}{c}\text { Carbonate } \\
\text { C } \\
\end{array}$ & $\mathrm{Ca}$ \\
\hline & $(\mathrm{mg} / \mathrm{kg})$ & $(\mathrm{mg} / \mathrm{kg})$ & $(\mathrm{mg} / \mathrm{kg})$ & $(\mathrm{mg} / \mathrm{kg})$ & $(\mathrm{mg} / \mathrm{kg})$ & $(\mathrm{mg} / \mathrm{kg})$ & (wt. \%) & (wt. \%) & $(\mathrm{mg} / \mathrm{kg})$ \\
\hline Sphalerite/Balmat & 1.3 & 200 & 6.7 & 2.9 & $<0.03$ & $<0.06$ & na & na & 1360 \\
\hline Sphalerite/Creede & 17 & 5300 & 120 & 29 & 0.23 & 0.12 & na & na & 103 \\
\hline Hemimorphite & 12 & 650 & 1600 & 48 & 31 & $<0.06$ & na & na & 18000 \\
\hline Smithsonite & 6.9 & 1300 & 41 & 2.4 & 0.27 & 9.0 & 20 & 5.5 & 10200 \\
\hline Hydrozincite & 31 & 560 & 70 & 6.2 & 0.31 & 0.23 & 13 & 3.6 & 13400 \\
\hline \multirow[t]{2}{*}{ Mineral } & $\mathrm{Cd}$ & $\mathrm{Ce}$ & Co & $\mathrm{Cr}$ & Cs & $\mathrm{Cu}$ & $\mathrm{Fe}$ & $\mathrm{Hg}$ & $\mathrm{Ga}$ \\
\hline & $(\mathrm{mg} / \mathrm{kg})$ & $(\mathrm{mg} / \mathrm{kg})$ & $(\mathrm{mg} / \mathrm{kg})$ & $(\mathrm{mg} / \mathrm{kg})$ & $(\mathrm{mg} / \mathrm{kg})$ & $(\mathrm{mg} / \mathrm{kg})$ & $(\mathrm{mg} / \mathrm{kg})$ & $(\mathrm{mg} / \mathrm{kg})$ & $(\mathrm{mg} / \mathrm{kg})$ \\
\hline Sphalerite/Balmat & 1100 & 0.3 & 0.91 & 1 & 0.02 & 48 & 62000 & 17 & 21 \\
\hline Sphalerite/Creede & 4100 & 16 & 23 & 1.9 & 0.12 & 792 & 26000 & 1.1 & 23 \\
\hline Hemimorphite & 1800 & 0.99 & 3.9 & 1.9 & 0.19 & 18 & 130000 & 0.75 & 2.3 \\
\hline Smithsonite & 3000 & 0.82 & 910 & 1.7 & 0.12 & 170 & 2000 & 0.86 & 1.3 \\
\hline Hydrozincite & 500 & 1.3 & 3.6 & 5.1 & 0.09 & 2300 & 240 & 2.9 & 0.78 \\
\hline
\end{tabular}


Appendix B. Bulk chemical composition of five zinc minerals.-Continued

[All results by inductively coupled plasma-mass spectrometry except mercury cold-vapor atomic fluorescence, and total carbon and total sulfur by LECO; na $=$ not analyzed; $<=$ less than; $\mathrm{mg} / \mathrm{L}=$ milligrams per liter; $\mu \mathrm{S} / \mathrm{cm}=$ micro Siemens per centimeter; $\mathrm{mg} / \mathrm{kg}=$ milligrams per kilogram; wt. $\%=$ weight percent]

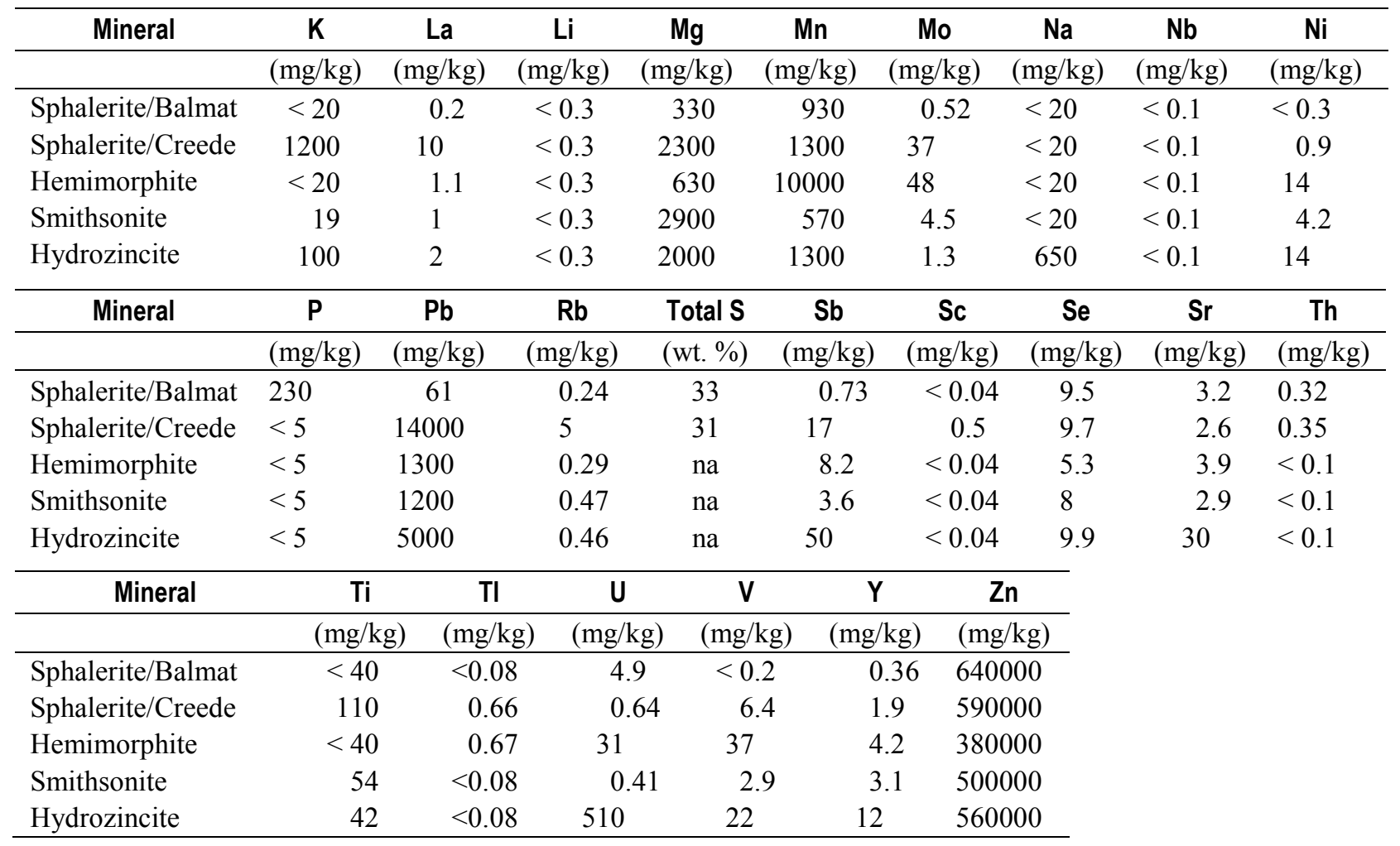

\section{Appendix C}

Appendix C. Complete leachate analytical chemistry results for five zinc-bearing minerals (AppendixC.x/sx)

\section{Appendix D}

Appendix D. Leachate concentrations as milligrams leached per kilogram solid for measured elements by mineral and as measured in simulated gastric fluid (SGF), simulated intestinal fluid (SIF), simulated lung fluid (SLF), and simulated phagolysosomal fluid (SPF). (AppendixD.xIsx) 